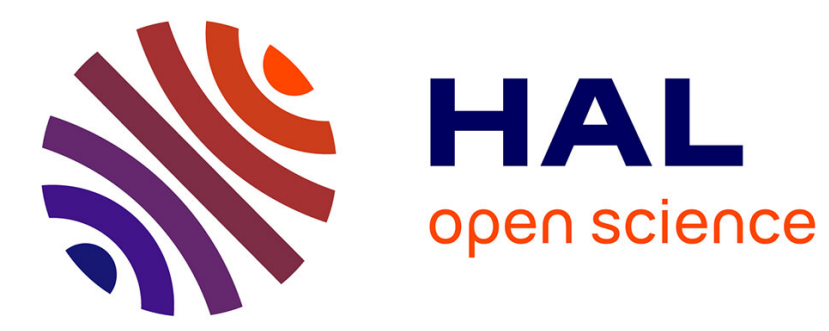

\title{
The role of melting on the geochemical evolution and isotopic variability of an anatectic complex in the Iberian Variscides
}

Joana Ferreira, João Mata, Telmo Bento dos Santos, Inês Pereira

\section{- To cite this version:}

Joana Ferreira, João Mata, Telmo Bento dos Santos, Inês Pereira. The role of melting on the geochemical evolution and isotopic variability of an anatectic complex in the Iberian Variscides. Lithos, 2020, 378-379, pp.105769. 10.1016/j.lithos.2020.105769 . hal-02969106

\section{HAL Id: hal-02969106 \\ https://hal.uca.fr/hal-02969106}

Submitted on 16 Oct 2020

HAL is a multi-disciplinary open access archive for the deposit and dissemination of scientific research documents, whether they are published or not. The documents may come from teaching and research institutions in France or abroad, or from public or private research centers.
L'archive ouverte pluridisciplinaire HAL, est destinée au dépôt et à la diffusion de documents scientifiques de niveau recherche, publiés ou non, émanant des établissements d'enseignement et de recherche français ou étrangers, des laboratoires publics ou privés. 
1 The role of melting on the geochemical evolution and

2 isotopic variability of an anatectic complex in the Iberian

3 Variscides

4

5 Joana A. Ferreira ${ }^{1,2^{*}}$, João Mata ${ }^{1,2}$, Telmo Bento dos Santos ${ }^{1,2}$, Inês Pereira ${ }^{3,4}$

6

$7 \quad{ }^{1}$ Instituto Dom Luiz (IDL), Faculdade de Ciências, Universidade de Lisboa, Campo 8 Grande, 1749-016, Lisboa, Portugal

92 Departamento de Geologia, Faculdade de Ciências, Universidade de Lisboa, C6, 10 Campo Grande, 1749-016 Lisboa, Portugal

$11{ }^{3}$ School of Earth and Environmental Sciences, University of Portsmouth, Building 12 Burnaby Rd Portsmouth P01 3QL, UK

${ }^{4}$ Laboratoire Magmas et Volcans, Université Clermont Auvergne, 6 avenue Blaise Pascal, TSA 60026 - CS 60026, 63178 Aubiere Cedex, France

${ }^{*}$ Corresponding author (jaferreira@fc.ul.pt)

17 Abstract: Formation and evolution of migmatite-granite terranes usually involve several complex petrological and geochemical processes that leave their imprint on elemental and isotopic signatures. In this paper, we assess the role of melting reactions on the genesis of the Variscan Figueira de Castelo Rodrigo-Lumbrales Anatectic Complex (FCR-LAC) at the Central Iberian Zone, culminating in the generation of abundant Stype granites. At odds with the proposed for several anatectic complexes elsewhere, it is demonstrated that no isotopic ( $\mathrm{Sr}-\mathrm{Nd}-\mathrm{Hf}-\mathrm{Pb})$ disequilibrium occurred in the FCR$\mathrm{LAC}$, in the transitions from metatexites to diatexites and, finally, to granites. However, 
variable contribution of the source minerals generated batches of melts characterized by distinct parent/daughter ratios, which explain the significant heterogeneity of present-day isotopic signatures. While $\mathrm{Rb} / \mathrm{Sr}$ ratios and the $\mathrm{Pb}$ budget of the successively generated lithotypes were mainly controlled by major minerals, such as muscovite, K-feldspar and plagioclase, the accessory phases played a major control on $\mathrm{Sm} / \mathrm{Nd}$ and $\mathrm{Lu} / \mathrm{Hf}$ ratios. Our study demonstrates the existence of two distinct diatexite groups produced by different reactions. Type- 1 diatexites, having high Rb contents and fractionated HREE, are geochemically more akin to the associated S-type granites. They were produced via fluid-absent reactions during dehydration-melting of muscovite with production of peritectic K-feldspar, sillimanite and melt. The less abundant type-2 diatexites required influx of external fluids during melting reactions, which consumed more plagioclase than muscovite.

Isotopic data reveal the existence of two groups with distinct initial compositions $\left(\varepsilon \mathrm{Nd}_{320}\right.$ $=-5.05$ to -6.03 and $\varepsilon \mathrm{Hf}_{320}=-3.42$ to -4.45 vs. $\varepsilon \mathrm{Nd}_{320}=-7.30$ to -8.89 and $\varepsilon \mathrm{Hf}_{320}=-6.45$ to -8.47 ), both composed of metatexites, diatexites and granites, which is explained by source heterogeneity. The main source of the anatectic complex was the metasedimentary Neoproterozoic - Lower Cambrian Douro-Beiras Supergroup, with minor contribution of the Ordovician Ollo de Sapo magmatic rocks.

Keywords: Anatectic complex; Melting reactions; Isotope geochemistry; Variscan Orogeny

1. Introduction

Late-stage mountain building is typically characterized by crustal anatexis and generation of granitic bodies, a common feature in the continental tectonic framework 
since the Archean (Whitney et al., 2004). Upper crust emplacement of granitic magmas leaving refractory residues leads to intracrustal differentiation, which explains the compositional distinction between lower and upper crust (Sawyer et al., 2011).

The production of large volumes of melt through partial melting of a source rock depends on protolith fertility, on the presence of fluids, and of on the temperaturepressure conditions, namely the magnitude of the thermal anomaly (Brown, 2013; Clemens, 2006). Metapelitic and metapsammitic rocks containing large amounts of hydrous phases, such as muscovite and biotite (30\% to $50 \%)$, are fertile protoliths and potential sources of peraluminous melts through metamorphic incongruent melting reactions (fluid-present or fluid-absent) at $700-800 \stackrel{\circ}{ }$ (Brown, 2013; Sawyer et al., 2011). Indeed, fluid-absent melting of micas in metapelites and metagreywackes can yield up to 50 vol\% of melt (Clemens and Vielzeuf, 1987; Sawyer et al., 2011; Bento dos Santos et al., 2011b; Brown, 2013). For these reasons, migmatite-granite complexes have been the target of several studies with the objective of exploring links between high-grade metamorphism, partial melting processes, the origin of the related granitic bodies and crustal differentiation (e.g. Johannes et al., 2003; Bento dos Santos et al., 2011a; Brown et al., 2016; Sola et al., 2013).

In the Iberian Variscan Belt (the southwestern sector of the European Variscan orogen), more precisely in the Central Iberian Zone (CIZ), several authors have emphasized the relationship between some granites and migmatitic rocks (Areias et al., 2014; Carríngton da Costa and Teixeira, 1957; Ferreira et al., 2014; Pereira et al., 2017; Ribeiro et al., 2011; Vanderhaeghe, 2009). The Figueira de Castelo RodrigoLumbrales Anatectic Complex (FCR-LAC) is one of such anatectic complexes and has the particularity of showing a clear spatial relationship between metatexites, diatexites and granites. In this way, this complex offers the opportunity to assess the melting reactions that genetically link migmatites (metatexites and diatexites), granites, and their metasedimentary sources. Links between the FCR-LAC granites and the hosting pre-Ordovician metasedimentary rocks have already been suggested by Ferreira et al. 
(2019), based on the study of inherited zircon grains, a question that will be readdressed in this paper.

Radiogenic isotopes are widely applied to identify source characteristics of magmatic rocks (e.g. White, 2010). Indeed, it is usually assumed that the isotopic composition of a magma is similar to that of the source rock, a hypothesis implying that no isotopic fractionation occurs during melting and that almost the same happens with the parent $(P) /$ daughter $(D)$ element pairs. This is true if each of the source mineral phases is not a significant repository of any of the $\mathrm{P}$ or $\mathrm{D}$ elements for the isotopic systems considered, i.e. when the P and D elements are highly incompatible. However, in silica-rich magmatic systems, such as S-type granites and related anatectic rocks, isotopic disequilibrium becomes more common (e.g. Himalayan leucogranites - Ayres and Harris, 1997; Anatectic Complex of Toledo - Barbero et al., 1995; Sierra Nevada Batholith - Tommasini and Davies, 1997; Southern Sierra Nevada - Zeng et al., 2005b; see also Wolf et al., 2019;). Indeed, residue/melt isotopic disequilibrium can take place due to a) insufficient temperature to reach the closure temperature of some of the accessory phases, with which $\mathrm{P}$ and/or $\mathrm{D}$ elements are compatible, resulting in a significant fractionation (up to $>20 \varepsilon \mathrm{Hf}$ units; Tang et al., 2014); and b) chemical diffusivity being sluggish compared with the time frame necessary for melt extraction from the residue (Ayres and Harris, 1997; Farina and Stevens, 2011; Zeng et al., 2005; Tang et al., 2014; Wolf et al., 2019). These factors can lead to the perception that isotopic disequilibrium during anatexis is ubiquitous (e.g. Tommasini and Davies, 1997). However, in some cases, even for situations specifically investigated for isotopic disequilibrium, no significant evidence-was found (e.g. Wolf et al., 2019). In this perspective, the isotopic variability of an anatectic complex must also be addressed in light of regional source heterogeneities (e.g. Yakymchuk et al., 2015, 2013), and on the role of melting reactions leading to distinct $P / D$ pairs with the consequent development of distinct isotopic signatures due to variable rates of radiogenic ingrowth through time. 
107 For these reasons, the importance of isotopic disequilibrium during anatexis is still 108 inconclusive.

109 Distinct isotopic systems are expected to behave differently during anatexis, with some of them responding variably to diverse melting conditions (e.g. Wolf et al., 2019). This confers to multi-isotopic studies the potential to investigate the hypothetical role of isotopic disequilibrium and source heterogeneity, as well as to better decipher the role of distinct melting reactions during the different stages of anatexis.

Therefore, in this study, we use $\mathrm{Sr}, \mathrm{Nd}, \mathrm{Hf}$ and $\mathrm{Pb}$ isotopes, the elemental whole-rock compositions, and zircon and apatite trace-element compositions from the FCR-LAC lithologies to: 1) assess the melting reactions behind the different lithotypes; 2) evaluate the potential role of isotopic disequilibrium during anatexis; 3) provide 4) explore the geochemical link between the different stages of anatexis, from migmatites to granites, and also to infer potential metapelitic protoliths.

\section{Geological Setting}

The European Variscan Belt is the result of a complex evolution culminating with the polyphasic collision of the continents Laurentia and Gondwana during the Devonian Carboniferous periods (e.g. Dias and Ribeiro, 1995; Nance et al., 2010). In the internal zones of the orogen, the continental collision produced the rapid formation of metamorphic core complexes, characterised by the exhumation of migmatites, large volumes of granitic magmas, and LP-HT metamorphism (Burg et al., 1994; Schulmann et al., 2002).

The FCR-LAC is located within the autochthonous terranes of the variscan Central Iberian Zone $(\mathrm{ClZ})$ and it is an example of a migmatite-granite complex formed during the Variscan Orogeny (e.g. Ferreira et al., 2019) (Fig. 1). This anatectic complex preserves significant field macroscopic evidence of the gradual anatectic evolution from 
metatexites, to diatexites and to syn-tectonic granites (Fig. 2). The FCR-LAC contacts with low-grade (biotite and chlorite zone) metamorphic units of Ediacaran-Cambrian (to the North and South) and Ordovician age (to the South) through the Huebra and the Juzbado-Penalva do Castelo shear zones, respectively. Their sinistral kinematics were active at least during the intracontinental collision stage $\left(D_{3}\right.$, third phase of the lberian variscan deformation; Pereira et al., 2017 and references therein), although it has been suggested that it represents a much older tectonic discontinuity (Iglesias and Ribeiro, 1981). The Juzbado-Penalva do Castelo shear zone (JPCSZ) is a $200 \mathrm{~km}$ long, 5 to 15 $\mathrm{km}$ wide first-order structure, with a proposed horizontal displacement between 65 and 100 km (Iglesias and Ribeiro, 1981; Villar Alonso et al., 2000). Geothermobarometric estimates using mineral equilibria point to peak metamorphic conditions of $T=761 \pm 50$ ${ }^{\circ} \mathrm{C}$ and $\mathrm{P}=5.0 \pm 1.0 \mathrm{kbar}$ (Pereira et al., 2017). Exhumation mechanisms of this anatectic complex have been widely discussed and two major models have been interpretation of the complete exhumation process of this granitic-migmatitic association must consider that this complex occurs in contact with low grade assisted exhumation process (Ferreira et al., 2019). 
The low-grade (chlorite-biotite zones) metamorphic units are composed of phyllites and quartzphyllites, affected by a nearly E-W schistosity (Fig. 3a). Phyllites in the vicinity of granites show post-deformation andalusite porphyroblast growth, usually pseudomorphosed, formed by contact metamorphism (Fig. 2a and Fig. 3b). The mineral assemblage of these phyllites also includes quartz, muscovite, biotite, and minor plagioclase and chlorite, as well as accessory titanite, zircon, apatite, rare staurolite, and opaque minerals.

Metatexites exhibit stromatic structures still preserving a pre-melting banded orientation inherited from the regional E-W schistosity (i.e. inherited fabric). Sometimes, centimetric or millimetric lenses of peritectic sillimanite associated to muscovite are found (Fig. 2b). Occasionally, metatexites are intersected by centimetric leucosome, sometimes boudinated, and filled with granitic to pegmatitic material (Fig. 2c). Leucosome patches up to $20-35 \mathrm{~cm}$, also occur in association with these veins (Fig. predominantly composed of a quartz-feldspar assemblage (Fig. 3c). Fibrolite appears as relic grains in late muscovite formed during retrogression (Fig. $3 \mathrm{~d}$ ). The most common accessory phases are zircon, apatite, tourmaline, staurolite and ilmenite.

Diatexites show structures such as restitic nodules (Fig. 2e), schlieren (Fig. 2f), and, occasionally, ptygmatic folding. Closer to the shear zones, diatexites reveal E-W oriented shear deformation planes, i.e. the same orientation as the shear zone. Locally, there are pegmatitic and leucosome veins forming vein-structured diatexites. Some of these diatexites show a near-nebulitic texture (only slightly more coarser-grained and biotite-enriched than the examples described in Sawyer (2008).. As a whole, diatexites comprise quartz, plagioclase, K-feldspar, biotite, minor fibrolitic sillimanite and 
secondary muscovite (Fig. 3f). Chemically, two different groups of diatexites can be distinguished (see section 6.2), which are not macroscopically distinguishable. However, thin section petrography reveals that the mineralogical composition is slightly different, with type-1 diatexites having more fibrolitic sillimanite and secondary muscovite, but lower amounts of K-feldspar than type-2 diatexites (Table 1).

Additional evidence of partial melting in these migmatites can be found in the occurrence of corroded grains of biotite and melt films (Fig. 3e), mainly in quartzfeldspar boundaries.

In general, the contact between the metatexites, diatexites and granites is marked by a gradual transition, but there are also injections of granitic material found in the migmatites, feeding the S-type plutons.

Granites are essentially two mica-bearing, with biotite and muscovite appearing in different proportions and with variable grain sizes. These variations led to their grouping onto 10 different granite facies (Silva and Ribeiro, 2000; Fig. 2g and Fig. 2h). Some granitic outcrops reveal deformation structures like those found in the migmatites, compatible with the JPCSZ movement (Fig. 3h). These granites are mainly composed of quartz, plagioclase, K-feldspar, biotite, muscovite (Fig. 3g) and minor fibrolitic sillimanite. Accessory mineral assemblage includes zircon, apatite, rutile needles and ilmenite.

Apatite from these granites yield $288-307 \mathrm{Ma}$, while newly grown zircon grains provide magmatic U-Pb crystallisation ages between 300 and $317 \mathrm{Ma}$ (Ferreira et al., 2019). However, a significant part of the zircon population is inherited (54\%), yielding ages in the range $400-650 \mathrm{Ma}$, having survived the melting and segregation stages.

\section{Analytical methods}

We report 55 analyses of whole-rock geochemistry of granites, migmatites and phyllites from the Douro-Beiras Supergroup that were conducted in the Activation Lab 
216 in Ontario, Canada. Major elements were measured by Fusion Inductively Coupled

217 Plasma Optical Emission Spectrometry and trace elements by Fusion Inductively 218 Coupled Plasma Mass Spectrometry (see details in the Supplementary Material 1).

219 Whole-rock isotopic analyses of $\mathrm{Sr}, \mathrm{Nd}, \mathrm{Hf}$ and $\mathrm{Pb}$ were performed in 13 samples, including 8 migmatites ( 5 metatexites, 2 type- 1 diatexites and 1 type-2 diatexite), 5 granites and 2 metasedimentary units from the Douro-Beiras Supergroup at the

222 Laboratoire G-Time of the Université Libre de Bruxelles (ULB, Belgium) using a Nu Plasma I Multi-Collector Inductively Coupled Mass Spectrometer (MC-ICP-MS) instrument (for more details see the Supplementary Material 1).

Zircon and apatite grains separated from the anatectic units were analysed for their trace element content using an ASI RESOlution $193 \mathrm{~nm}$ ArF excimer laser coupled to the ANALYTIK JENA Plasma Quant Elite quadrupole ICP-MS at the University of Portsmouth (UoP) (see more analytical details in the Supplementary Material 1).

\subsection{Whole-rock elemental geochemistry}

Whole-rock elemental compositions are presented in Table 2, where the studied samples are grouped as phyllites, metatexites, diatexites and granites.

Phyllites and metatexites are enriched in $\mathrm{Al}_{2} \mathrm{O}_{3}, \mathrm{FeO}^{t}, \mathrm{MgO}$ and $\mathrm{TiO}_{2}$ in comparison to diatexites and granites, evidencing a negative correlation with silica (Fig. 4). This reflects the larger abundance of refractory minerals (e.g. biotite and titanite) in the metasedimentary protoliths and in the metatexite's melanosomes, representative of an incipient degree of partial melting. On the other hand, diatexites and granites commonly yield higher contents of $\mathrm{SiO}_{2}, \mathrm{Na}_{2} \mathrm{O}, \mathrm{K}_{2} \mathrm{O}$ and $\mathrm{P}_{2} \mathrm{O}_{5}$ when compared to metatexites. This difference is consistent with higher degree of partial melting and, eventually the occurrence of some crystal fractionation (e.g. Sawyer, 2008), and, thus, with the production of quartz-plagioclase-, K-feldspar- and apatite-rich melts. Two types 
243 of diatexites were identified mainly based on their composition (Fig. 4): type-1 244 diatexites $\left(\mathrm{SiO}_{2}=68-74 \mathrm{wt} \%\right)$ and type-2 diatexites $\left(\mathrm{SiO}_{2}=74-75 \mathrm{wt} \%\right)$. 245 Additionally, type-2 diatexites are distinguishable by a wider variation of $\mathrm{Na}_{2} \mathrm{O}$ 246 concentration, slightly lower average $\mathrm{Fe}_{2} \mathrm{O}_{3}{ }^{\mathrm{t}}$ content and lower concentrations of $\mathrm{P}_{2} \mathrm{O}_{5}$, 247 which are similar to the depicted by metatexites and phyllites.

248 All lithotypes display high $\mathrm{Al}_{2} \mathrm{O}_{3}$ content $\left(\mathrm{Al}_{2} \mathrm{O}_{3}>12\right.$ wt.\%), being strongly 249 peraluminous (phyllites: $\mathrm{ASI}=2.0-3.3$, quartzphyllites: $\mathrm{ASI}=1.2-2.4$, metatexites: $250 \mathrm{ASI}=1.5-2.7$, diatexites: $\mathrm{ASI}=1.1-1.5$, and granites: $\mathrm{ASI}=1.1-1.4)$.

251 The resemblance between metatexites and phyllites, revealed by major elements, is also generally depicted by trace elements (Fig. 5). Type-2 diatexites exhibit lower Rb contents compared to the other anatectic rocks, but similar to metasediments. Phyllites, quartzphyllites, and metatexites have significantly similar patterns in the multi-element diagrams, showing negative anomalies of $\mathrm{Nb}, \mathrm{K}, \mathrm{Pb}, \mathrm{Sr}$ and $\mathrm{Ti}$, and positive anomalies of $\mathrm{U}, \mathrm{Ta}, \mathrm{La}, \mathrm{Ce}$ and $\mathrm{Nd}$ (Fig. 6a). $\mathrm{Zr}$ and $\mathrm{Hf}$ positive anomalies are evident in the quartzphyllites (Fig. 6a), as the result of their higher zircon contents (observed under the microscope), in agreement with their more psammitic characteristics in comparison with the remaining metasediments. Multi-element patterns of diatexites and granites overlap within error (Fig. 6b), exhibiting a wide range of values for some elements, such as Th, REE and $\mathrm{Zr}$ - $\mathrm{Hf}$. Both lithotypes show negative anomalies for $\mathrm{Nb}, \mathrm{Pb}, \mathrm{Sr}$ and $\mathrm{Ti}$. There are some similarities between metasediments/metatexites and diatexites/granites, as all yield $\mathrm{Nb}, \mathrm{Pb}, \mathrm{Sr}$ and $\mathrm{Ti}$ anomalies (Fig. $6 \mathrm{a}$ and $6 \mathrm{~b}$ ).

REE composition data are summarized in Table 2 and Figure 7. Phyllites, quartzphyllites and metatexites have almost identical normalised patterns (Fig. 7a), with all but one sample being included in a very limited concentration range (e.g. La = 41 to $61 \mathrm{ppm} ; \mathrm{Yb}=2.2$ to $3.5 \mathrm{ppm})$. The exception is one metatexite sample (JTJ-60A) which stands out of the group, because of its lower REE contents $(\mathrm{La}=18 ; \mathrm{Yb}=1.4)$, but yet yielding similar $(\mathrm{La} / \mathrm{Yb})_{N}$ ratios $(7.43$ to 13.35). The Heavy Rare Earth Elements (HREE) are weakly fractionated $\left(\mathrm{Dy} / \mathrm{Yb}_{\mathrm{N}}=1.07-1.35\right)$ and the Eu anomalies are small 
$271\left(\mathrm{Eu}_{\mathrm{Eu}} \mathrm{u}^{*}=0.5-0.7\right)$. Diatexites and granites display a wide range of $\mathrm{REE}$

272 concentrations ( $\Sigma=8-777 \mathrm{ppm})$ (Fig. 7b and 7c), despite the studied granites having 273 similar normalised patterns across the different facies. At odds, diatexites have a wider 274 variability, showing different degrees of HREE fractionation (Dy/ $/ \mathrm{Yb}_{\mathrm{N}}=0.8$ to 5$)$ and $\mathrm{Eu}$ anomalies, either negative (down to 0.2 ; type-1 diatexites) or positive (up to 4 ; type-2 diatexites). See section 6.2 for more details on the chemical differences between these two types of diatexites.

\subsection{Accessory minerals: trace element composition}

\subsubsection{Apatite}

The trace element compositions of apatite grains from the FCR-LAC and their host rocks (phyllites) are remarkably distinct in $\mathrm{Sr}, \mathrm{Y}$, Th and REE compositions (Table 3; Fig. 8a-8e). The highest Sr content in apatite was found in phyllites (317 - 1471 ppm), decreasing gradually in metatexites (113 - $487 \mathrm{ppm})$, diatexites (86 - $144 \mathrm{ppm})$ and granites $(74-99 \mathrm{ppm})$. Thorium behaves similarly. On the other hand, $\mathrm{Y}$ contents in apatite are low in phyllites (480 - 854 ppm), are quite similar between metatexites (837 - 1973 ppm) and diatexites (847 - 2026 ppm) and show a large range in granites (212 - 1546 ppm). Concerning their $U$ composition, phyllites reveal lower values $(8-34$ ppm), while metatexites exhibit a larger variation $(17-223 \mathrm{ppm})$, identical to that of diatexites (33 and $185 \mathrm{ppm}$ ). The maximum $U$ concentration in the diatexites corresponds to a type-2 diatexite. The variation of $U$ in granites is smaller, but within the same range of values as the migmatites (49 and $81 \mathrm{ppm}$ ).

Apatite grains are highly enriched in REE with $\Sigma$ REE ranging from 1397 to 5829 . They all show a marked enrichment in LREE compared to HREE, as depicted by $(\mathrm{La} / \mathrm{Yb})_{\mathrm{n}}$ ratios $($ Fig. 8f; phyllites $=5.1-32.6$, metatexites $=0.6-3.7$, diatexites $=0.6-$ 6.8 and granites $=3.7-19.1$, yet $(\mathrm{La} / \mathrm{Sm})_{\mathrm{n}}$ ratios are lower than the unity, except in Il $\gamma$ 
granite. At odds, apatite $(\mathrm{Tb} / \mathrm{Lu})_{n}$ ratios are clearly higher than 1 for all the lithotypes. The Ily granite has a REE fractionation higher than the remaining granite facies, because of its higher LREE contents. In general, Eu anomalies are negative with the exception of the late-tectonic granite (granite lly: 1.06), which lacks an anomaly.

\subsubsection{Zircon}

Contents of $\mathrm{Hf}, \mathrm{Y}, \mathrm{U}, \mathrm{Th}$ and HREE in zircon grains exhibit positive correlations with those from the whole rock, indicating that zircon controls the budget of these elements in migmatites and granites (Table 4; Fig. 13b and Fig. 13c). Hf contents are similar between metatexites $(8180-14410$ ppm), diatexites (11060 - 12750 ppm) and granites (10280 - $12670 \mathrm{ppm})$. Lu values decrease in zircon grains from metatexites $(48-309 \mathrm{ppm})$, to diatexites (48 - $91 \mathrm{ppm})$, and to granites (14 - $58 \mathrm{ppm})$. We were only able to determine $Y$ contents for half the measured points (11 out of 23). For the available measurements, metatexites yield 120 - 2074 ppm, diatexites 610 ppm, and granites range between $469-1199 \mathrm{ppm}$. $\mathrm{U}$ and Th contents are highly variable, with $\mathrm{Th} / \mathrm{U}$ ratios in zircon from diatexites $(0.06-0.11)$ and granites $(0.11-5.88)$ being broadly higher than 0.1 (10 spots out of 12), whereas metatexites yield a wide range $(0.003-0.845)$, with half the analysed grains showing ratios lower than 0.1 (6 of the 11 spots).

Zircon from the different units exhibit high and similar $\Sigma$ HREE concentrations, here considered from Eu to Lu (Fig. 8g), ranging from 490 to 2430 ppm in metatexites, 488 to $1679 \mathrm{ppm}$ in diatexites, and 261 to $2540 \mathrm{ppm}$ in granites. They also show Eu negative anomalies (metatexites $0.16-0.52$, diatexites $0.14-0.33$ and granites $0.02-$ 0.16). On the other hand, zircon from the different FCR-LAC rocks show Ce positive anomalies, suggesting high amounts of $\mathrm{Ce}$ in $4^{+}$valence, which allowed its greater incorporation (Trail et al., 2012). Most zircon in the metatexites have La below the detection limit, so to a better estimation of the REE fractionation, $\mathrm{Ce} / \mathrm{Yb}_{\mathrm{N}}$ is used. REE 
325 fractionation values $\left(\mathrm{Ce} / \mathrm{Yb}_{N}\right)$ in zircon retrieved from the metatexites are the most fractionated $\left(\mathrm{Ce} / \mathrm{Yb}_{\mathrm{N}}=0.00001-0.05\right)$, while zircon from granites and diatexites clearly yield more elevated values $\left(\mathrm{Ce} / \mathrm{Yb}_{\mathrm{N}}=0.01-0.4\right.$ and $0.001-0.04$, respectively) (Fig. 8g). Overall, $\mathrm{Lu} / \mathrm{Hf}$ ratios in zircon from the different units are variable, decreasing from metatexites (0.015), to diatexites $(0.006)$ and granites 330 (0.003).

\subsection{Isotopic geochemistry}

The radiogenic isotopes presented in this study were recalculated to $320 \mathrm{Ma}$, which corresponds to the migmatization age of the autochthonous domain of the CIZ (318 325 Ma, Martínez Catalán et al., 2014; Ferreira et al., 2019) (Table 5). While in the previous section, granites were presented as a single lithological group, in this section they are presented as syn-tectonic granites and late-tectonic granites (Ferreira et al., 2019). Likewise, phyllites are presented as phyllite $N$ and phyllite $S$, depending if they were collected to the North $(\mathrm{N})$ or South $(\mathrm{S})$ of the anatectic complex.

\subsection{1. $\mathrm{Sr}, \mathrm{Nd}$ and $\mathrm{Hf}$ isotopic compositions}

All migmatitic and granitic samples, except two, plot in the fourth quadrant (radiogenic $\mathrm{Sr}$ and less radiogenic $\mathrm{Nd}$ ) of the ${ }^{87} \mathrm{Sr}^{86} \mathrm{Sr}_{320}$ vs. $\varepsilon \mathrm{Nd}_{320}$ diagram (Fig. 9a), implying time-integrated evolution characterized by enrichment of $\mathrm{Rb}$ and $\mathrm{Nd}$ relatively to the less incompatible Sr and Sm, respectively.

Granites share similar $\varepsilon \mathrm{Nd}_{320}$ values (-6.03 to -8.89$)$, but significantly different ${ }^{87} \mathrm{Sr}^{86} \mathrm{Sr}_{320}$ ratios $(0.7022$ to 0.7126$)$. These compositions are compatible with the upper continental crust (Chauvel et al., 2014; Hart et al., 1999). Overall, metatexite compositions are similar to those of granites with ${ }^{87} \mathrm{Sr}^{86} \mathrm{Sr}_{320}$ values ranging between 0.7039 and 0.7124 and $\varepsilon \mathrm{Nd}_{320}$ between -5.21 to -8.86 . 
The metasedimentary units, phyllite $\mathrm{N}\left({ }^{87} \mathrm{Sr}^{86} \mathrm{Sr}_{320}=0.7153 ; \varepsilon \mathrm{Nd}_{320}=-10.07\right)$ and phyllite $S\left({ }^{87} \mathrm{Sr} /{ }^{86} \mathrm{Sr}_{320}=0.7089 ; \varepsilon \mathrm{Nd}_{320}=3.28\right)$, have distinct compositions but both plot in the field defined for the Douro Group (see Teixeira, 2008). The phyllite $S$ is also strikingly different from the FCR-LAC in terms of its Nd composition. Most granites and metatexites show similar compositions to that of the syn-tectonic Aguiar da Beira muscovite-biotite leucogranite (see Costa et al., 2014), while two samples of diatexite and one sample of metatexite have similarities with the Ollo de Sapo gneisses (see Montero et al., 2017; Fig. 9b).

The anatectic units have enriched $\mathrm{Hf}$ isotopic compositions that result in $\varepsilon \mathrm{Hf}_{320}$ ranging from -3.42 to -9.25 . Except for facies Ily $\left(\varepsilon \mathrm{Hf}_{320}=-3.99\right)$, granites have similar $\varepsilon \mathrm{Hf}_{320}$ compositions $(-7.70$ to -8.43$)$. The peculiar composition of Ily facies can be related to the fact that this granite is a $300 \mathrm{Ma}$ late-tectonic granite, whereas the remaining granites are syn-tectonic, with ages between 313 and $317 \mathrm{Ma}$ (Ferreira et al. 2019). Hf isotopic compositions of the metasedimentary units show distinct compositions (phyllite $\mathrm{N}$ with $\varepsilon \mathrm{Hf}_{320}=-13.68$ and phyllite $\mathrm{S}$ with $\varepsilon \mathrm{Hf}_{320}=-7.16$ ). The $\varepsilon \mathrm{Nd}_{320}$ vs. $\varepsilon \mathrm{Hf}_{320}$ diagram shows an overall positive correlation defined by the granites, metatexites and some diatexites (Fig. 9c). Despite some isotopic variability, two tight clusters are noticeable in the $\varepsilon \mathrm{Nd}_{320}$ vs. $\varepsilon \mathrm{Hf}_{320}$ diagram, each including granites, metatexites and type-1 diatexites. Type-2 diatexite reveals a $\varepsilon \mathrm{Nd}_{320}$ composition between the two clusters.

Phyllites, $\mathrm{N}$ and $\mathrm{S}$, yield two-stage $\mathrm{Nd}$ model ages $\left(\mathrm{TDM}_{2}\right)$ of $1.83 \mathrm{Ga}$ and $779 \mathrm{Ma}$, respectively. The range of $\mathrm{Nd} \mathrm{TDM}_{2}$ ages for the metatexites is 1.45 to $1.73 \mathrm{Ga}$, for the diatexites is 1.43 to $1.69 \mathrm{Ga}$, and for the granites is 1.51 to $1.73 \mathrm{Ga}$. The $\mathrm{Hf} \mathrm{TDM}_{2}$ ages are older, displaying the following values: phyllite $N(2.16 \mathrm{Ga})$, phyllite $S(1.75 \mathrm{Ga})$,

375 metatexites (1.57 to $1.83 \mathrm{Ga})$, diatexites $(1.51$ to $1.88 \mathrm{Ga})$, and granites $(1.54$ to 1.83

$376 \mathrm{Ga}$ ). These $\mathrm{Nd}$ and $\mathrm{Hf}$ model ages are similar for most of the anatectic complex 377 lithologies (granites, diatexites, and metatexites). $\mathrm{Nd} \mathrm{TDM}_{2}$ for the phyllite S sample is 
378 different and younger than the remaining analysed lithologies, and also somewhat 379 different regarding its $\mathrm{Hf} \mathrm{TDM}_{2}$.

380

\subsection{2. $\mathrm{Pb}$ isotopic composition}

382

383

When recalculated to $320 \mathrm{Ma}$, the $\mathrm{Pb}$ isotopic ratios retrieved from phyllites become clustered onto one group with the remaining lithologies, in oppositition to what was shown for the $\mathrm{Sr}, \mathrm{Nd}$, and $\mathrm{Hf}$ isotopic systems in section 5.3.1. The ${ }^{206} \mathrm{~Pb} /{ }^{204} \mathrm{~Pb}_{320}$ and ${ }^{207} \mathrm{~Pb} /{ }^{204} \mathrm{~Pb}_{320}$ isotopic ratios tend to be almost identical for all lithologies $\left({ }^{206} \mathrm{~Pb} /{ }^{204} \mathrm{~Pb}_{320}\right.$ $=17.24$ to 18.27 and ${ }^{207} \mathrm{~Pb} /{ }^{204} \mathrm{~Pb}_{320}=15.61$ to 15.67 ), with the exception of one metatexite outlier (Fig. 10a). In comparison, the ${ }^{208} \mathrm{~Pb} /{ }^{204} \mathrm{~Pb}_{320}$ isotopic ratio (36.67 to 39.39) is slightly more variable (Fig. 10b).

\section{Discussion}

\subsection{Granite systematics}

The intimate field relationship between granites, migmatites and metasediments in the FCR-LAC suggests a genetic link between these lithotypes. This is supported by the granites plotting close to ternary minimums in the Ab-Or-Q ternary diagram (Fig. 11c; Tuttle and Bowen, 1958; Winter, 2014). This points out to the S-type character of the studied granites, which is also suppported by their peraluminous character (ASI > 1.1) (Fig. 11a) and by their positioning in the A-B granite classification diagram of Villaseca et al. (1998) (Fig. 11b). Low $\mathrm{CaO}$ (0.2 - 1 wt.\%), $\mathrm{Na}_{2} \mathrm{O}$ (in general $<3.2$ wt.\%), and high $\mathrm{K}_{2} \mathrm{O}\left(\approx 5\right.$ wt.\%) contents, as well as ${ }^{87} \mathrm{Sr}^{86} \mathrm{Sr}_{320}$ ratios up to 0.7124 are also typical of S-type granites (Chappell and White, 1974). ${ }^{87} \mathrm{Sr}^{86} \mathrm{Sr}_{320}$ ratios are somewhat variable $(0.7039-0.7124)$, reflecting variability between different granite facies. This variability, typical of S-type granites (Chappell and White, 2001), can be a 
consequence of heteregeneous protoliths or reflect isotopic disequilibrium (see below). The tight clustering of granites and migmatites in the $\varepsilon \mathrm{Nd}_{320} v s . \varepsilon \mathrm{Hf}_{320}$ plot (Fig. 9c) puts in evidence the cogenetic association amongst these units, which reinforces their characterisation as S-type granites.

The abundant presence of perthites indicates the hypersolvus character of these granites, compatible with relatively low $\mathrm{H}_{2} \mathrm{O}$ pressure, which is also suggested by the positionning between the ternary minimum defined at 0.1 and $0.2 \mathrm{GPa}$ in the Ab-Or-Q ternary diagram (Fig. 11c).

\subsection{The diatexite-granite link}

In an anatectic complex, diatexites are regarded as the result of melting processes which by melt aggregation, migration, and emplacement give rise to granitic intrusive bodies (Milord et al., 2001). Diatexites in the FCR-LAC are characterized by a significant compositional variability, which can provide clues on the shared genetic link with granites.

Major and trace element concentrations were used to geochemically separate distinct types of diatexites: type-1 $\left(\mathrm{SiO}_{2}=68-74 \mathrm{wt} \%\right)$ and type-2 $\left(\mathrm{SiO}_{2}=74-75\right.$ wt\%), whereas granites $\left(\mathrm{SiO}_{2}=70-75 \mathrm{wt} \%\right)$ are generally less silica-enriched than type-2 diatexites. Using the Frost et al. (2001) diagram, type-1 diatexites and granites are alkali-calcic to alkalic, whereas type-2 diatexites range between the alkali-calcic and calc-alkalic (Fig. 11d). Regarding trace element compositions, type-2 diatexites also stand out by their lower Rb (145 - 238 ppm) (Fig. 5a) and higher $\mathrm{Yb}$ and Lu concentrations (Fig. 6b), and flat $\mathrm{Tb}$ to $\mathrm{Yb}$ patterns $\left(\mathrm{Tb} / \mathrm{Yb}_{\mathrm{N}}=0.8-1.5\right)$ (Fig. $\left.7 \mathrm{~b}\right)$, at odds with what can be observed in the other diatexites and granites (Fig. 7b and 7c) $\left(\mathrm{Tb} / \mathrm{Yb}_{\mathrm{N}}>\right.$ 2.64). In addition, type-1 diatexites exhibit fractionated HREE $\left(\mathrm{Dy} / \mathrm{Yb}_{\mathrm{N}}=2\right.$ 5) and Eu negative anomalies (0.2 - 0.7), in contrast with type-2 diatexites, which 
reveal unfractionated HREE $\left(\mathrm{Dy} / \mathrm{Yb}_{\mathrm{N}}=0.8-1\right)$ and Eu anomalies from slightly negative

431

432

433

434

435

436

437 to strongly positive $(0.6-4)$.

Comparing both types of diatexites with granites, it is evident the similarity between granites and type-1 diatexites. Taking into account the differences between these two types of diatexites, type-2 could correspond to cumulates of quartz and feldspar that evolved isolated from type-1 diatexites and granites through an earlier fractional crystallization process (e.g. Brown et al., 2016; Morfin et al., 2014; Sawyer, 1987). The $\mathrm{Hf}$ isotopic signatures of these two types of diatexites are clearly distinct, with $\varepsilon_{\mathrm{Hf}_{320}}$ of the type-2 diatexites being significantly less radiogenic (up to 6 units; Table 5) than the reported for type-1 diatexites and also for the studied granites. Thus, the $\mathrm{Hf}$ isotopic data reinforces the idea of existing two distinct types of diatexites and of a genetic link between type-1 diatexites and granites, which is not so obvious when type-2 diatexites are considered. The role of melting reactions in this variability is potentially significant and is discussed in the following section.

Taking into account the referred isotope similitude with granites (see above), type-1 diatexites are here considered as related to the granites by melt-residuum separation. This process is evident in the Harker diagrams (Fig. 4), where this type of diatexites are tendentially more rich in $\mathrm{FeO}^{t}, \mathrm{MgO}, \mathrm{TiO}_{2}$ and $\mathrm{Al}_{2} \mathrm{O}_{3}$, but comparatively depleted in $\mathrm{K}_{2} \mathrm{O}$, $\mathrm{Na}_{2} \mathrm{O}$ and $\mathrm{SiO}_{2}$ than the associated granites.

\subsection{Melting reactions}

The formation of migmatite-granite complexes is the culmination of high-grade metamorphism during orogenic events. Partial melting is a sequential process where the production and accumulation of melt gradually increases with time. As prograde reactions take place, melting of the protolith lead to the formation of metatexitic and diatexitic migmatites, culminating with a granitic melt at higher melt fractions (Brown, 2013). Melting reactions can take place at different temperatures, pressures and water 
contents. Typically, pelitic and greywacke protoliths begin to melt at about $650-700 \stackrel{\circ}{C}$ in the presence of an aqueous fluid (fluid-present reactions), producing up to $60 \mathrm{vol} . \%$ of melt (Brown, 2013; Milord et al., 2001; Vielzeuf and Holloway, 1988; Weinberg and Hasalová, 2015). During the prograde metamorphic path, as temperature increases to ca. 800-1000 ${ }^{\circ} \mathrm{C}$, partial melting can occur in the absence of an external fluid, giving place to a series of fluid-absent reactions by dehydration of hydrous minerals, such as micas and amphiboles, which progressively increases melt production up to 70 modal percent melt (Brown, 2013; Bucher and Grapes, 2011; Yakymchuk and Brown, 2014).

Field observations combined with major element geochemistry of the FCR-LAC 466 units show that the most probable protolith of the granitic melts (s.I.) is of sedimentary origin (see sections 2 and 6.1). Moreover, the major elements geochemistry, in particular the $\mathrm{CaO} / \mathrm{Na}_{2} \mathrm{O}$ ratio, reinforces the idea that FCR-LAC granites are derived from pelitic melts $\left(\mathrm{CaO} / \mathrm{Na}_{2} \mathrm{O}<0.3\right.$; Jung and Pfänder, 2007) (Fig. 12a). The type of melting reactions can be inferred based on trace-element modelling using $\mathrm{Rb}, \mathrm{Ba}, \mathrm{Sr}$ (Inger and Harris, 1993) and taking into account the mineral assemblages of the FCRLAC rocks (section 3). Yet, the exact reaction cannot be accurately determined given its high dependence on the chemical and modal composition of the protolith, which in the present study is thought to be significantly heterogeneous on basis of several distinct characteristics for some key trace-elements, which are constrained by relative mass proportions of consumed feldspar and mica (Inger \& Harris, 1993; Gao et al., 2017; Dou et al., 2019). The role of these two reaction types on the evolution of the studied anatectic complex (FCR-LAC) is well evident on diagrams involving elements compatible with plagioclase or muscovite (Fig. 12b; Fig. 12c). 
The operation of fluid-present reaction is characterized by the development of evolution trends with almost constant $\mathrm{Rb} / \mathrm{Sr}$ ratios but highly variable $\mathrm{Sr}$ and $\mathrm{Ba}$ contents (e.g. Gao et al., 2017; Dou et al., 2019), which at FCR-LAC (Fig. 12b and 12c) encompass phyllites and most of the metatexites.

Petrographic observations indicate that the metatexite melanosomes are characterized by a lower plagioclase/muscovite proportion than the phyllites from where they are considered to have been derived. This suggests that the following fluidinduced key reaction (Patiño Douce and Harris, 1998; Weinberg and Hasalová, 2015) occurred during the initial steps of melting:

493 formation) resulted from such congruent fluid-present reaction (1), consuming plagioclase in larger quantities than muscovite (see also Dou et al., 2019; Gao et al., 2017; Martini et al., 2019).

502

As temperature increases during prograde metamorphism, fluid-absent melting can take place by the consumption of hydrous minerals, such as micas. A significant increase of $\mathrm{Rb} / \mathrm{Sr}$ ratios accompanied by a decrease of $\mathrm{Sr}$ and $\mathrm{Ba}$ is observed for granites and most type-1 diatexites (Fig. 12b and 12c), suggesting dehydration-melting involving the significant consumption of muscovite and crystallization of peritectic minerals, such as K-feldspar and sillimanite, in a reaction that could have been similar to (2) (Patiño Douce and Harris, 1998; see also Gao et al., 2017; Inger and Harris, 1993; Yang et al., 2019): 
This reaction also involves the crystallization of peritectic minerals, such as $\mathrm{K}$ feldspar and sillimanite. This agrees with the absence of primary muscovite in type-1 diatexites and granites, as well as the abundance of K-feldspar and sillimanite. Reaction (2) also explains the negative Eu anomalies characterizing most of type-1

517 diatexites and granites $\left(\mathrm{Eu} / \mathrm{Eu}^{*}\right.$ down to 0.2$)$, which can be explained by the 518 crystallization of peritectic K-feldspar (Fig. 12d; Dou et al., 2019; Gao et al., 2017).

519 After fluid-absent reactions involving the consumption of muscovite, it is commonly described the dehydration-melting of biotite as a response to temperature increase along the metamorphic path. There is some petrographic evidence stemming from migmatites for the breakdown of biotite, such as the occurrence of biotite crystals with corroded borders. However, reactions involving the melting consumption of biotite are accompanied by the peritectic production of garnet $(>0.4 \mathrm{GPa})$ or cordierite $(<0.4$ GPa) (Spear et al., 1999; Bento dos Santos et al., 2011). Such minerals were not detected in the studied samples, although garnet has been reported (Díez Fernández and Pereira, 2016), and therefore some incipient melting of biotite should have occurred.

We demonstrated before the existence of two geochemically distinct types of 530 diatexites (see section 6.2) and that type-1 diatexites were derived from fluid absent 531 reactions (2) associated to the dehydration-melting of muscovite. Type-2 diatexites 532 exhibit positive Eu anomalies ( $\mathrm{Eu} / \mathrm{Eu}^{*}$ up to 4), but low $\mathrm{CaO}$ contents and $\mathrm{Rb} / \mathrm{Sr}$ ratios 533 (Fig. 12b; 12c), compared to the remaining granites and type-1 diatexites. This implies that peritectic K-feldspar was not formed or only crystallized in small proportions (Dou et al., 2019; Gao et al., 2017), and, instead, another process must have been

536 important. Fluid-fluxed melting of muscovite (reaction 1) is a more likely mechanism to 537 generate melts with compositions similar to type-2 diatexites. The melt productivity of 538 such reaction is dependent on the amount of fluid present in the rock. The lower 539 abundance of type-2 diatexites and the lack of granites with compositions compatible 
540 with this type of diatexites suggest that the amount of melt generated by that fluid-

541 present reaction was not enough to promote the melt segregation/extraction needed to

542 granite generation. This suggests that the amount of fluid in the source rock was small.

543 Yet, as mentioned in section 6.2, the relative higher silica content in type-2 diatexites

544 suggests that their composition probably reflect, in addition, the occurrence of some

545 fractional crystallization.

546 Ti-in-zircon temperatures from young zircon grains within the syn-tectonic granites

547 range between $783-836{ }^{\circ} \mathrm{C}$ (Ferreira et al., 2019), implying that the metamorphic

548 peak reached such temperatures. Additionally, this range of estimated melt

549 temperatures are consistent with the minimum metamorphic peak temperature

550 previously calculated from mineral equilibria for the FCR-LAC $(T=761 \pm 50 \stackrel{\circ}{ } \mathrm{C}$; Pereira

551 et al., 2017). At this temperature range, up to $60 \%$ volume of melt is produced by the

552 referred partial melting reactions (Vielzeuf and Holloway, 1988), thus allowing

553 significant melt extraction given that the critical melt percentage for melt migration (20

554 to 35\% volume; e.g. Clemens and Vielzeuf, 1987 and Bento dos Santos et al., 2011a;

$555 \leq 7 \%$; Rosenberg and Handy, 2005 and Brown, 2013) is clearly surpassed.

556

$557 \quad 6.4$ The role of accessory minerals

558 Accessory minerals have an important role controlling the composition of trace 559 elements and isotopic ratios in migmatites and granites (e.g. Ayres and Harris, 1997;

560 Bea, 1996a, 1996b; Bea et al., 1994; Yakymchuk and Acosta-Vigil, 2019; Zeng et al., 561 2005a). Apatite and zircon are the main accessory minerals that occur in the FCR-LAC 562 rocks and their trace element compositions are described in section 5.2.

563 Results demonstrate that apatite is the main carrier of LREE and $Y$ in the FCR-LAC 564 (Table 3) and exhibits a flat REE pattern (more evident for LREE; Fig. 8a), typical of 565 peraluminous rocks (Bea, 1996a). The moderate LREE and $\mathrm{P}_{2} \mathrm{O}_{5}$ covariation observed 
566 in the whole-rock geochemistry (Fig. 13a) confirm the control that apatite has in the 567 variation of these elements.

568 Conversely, the HREE composition of the anatectic rocks is mainly influenced by 569 zircon (Table 4). This influence is also confirmed by the covariation between HREE and $570 \mathrm{Zr} / \mathrm{Hf}$ from the whole-rock geochemistry (Fig. 13b-d). Granites show depletion in the

571 HREE and lower Lu/Hf ratios when compared to metatexites and the country rocks, 572 which is due to the role of zircon. Indeed, Lu is preferentially retained in restitic zircon 573 grains during partial melting, resulting in a constant decrease of the Lu concentration and $\mathrm{Lu} / \mathrm{Hf}$ ratio in subsequent crystallised zircons.

Inherited zircon grains are quite common in all these granites, indicating survival of significant amounts of zircon, in agreement with partial melting experimental data. Indeed, considering an average $\mathrm{Zr}$ bulk-rock composition of $150 \mathrm{ppm}$ (Table 2), an estimated maximum melting temperatures of $\sim 840{ }^{\circ} \mathrm{C}$ (section 6.3 ) and an approximate $1: 1$ proportion of metapelite and greywacke in the protolith, only about $15 \%$ of zircon is expected to dissolve into the melt (Yakymchuk et al., 2017).

Apatite grains found in the metasedimentary units are highly enriched in LREE (La up to $1595 \mathrm{ppm}$ ) and Th (up to $97 \mathrm{ppm}$ ), which is a typical feature of magmatic apatite (Henrichs et al., 2018). Therefore, it is plausible that these correspond to detrital magmatic-derived apatite grains. The recrystallization of apatite during prograde metamorphism can explain the relative depletion of LREE (La $\leq 405 \mathrm{ppm}$ ) in the metatexitic apatite, typical of metamorphic apatites (Henrichs et al., 2018).

\subsection{Isotope variability}

The studied rocks form two tight clusters in the $\varepsilon \mathrm{Hf}_{320}$ vs. $\varepsilon \mathrm{Nd}_{320}$ diagram (Fig. 9c) , each of them comprising metatexites, diatexites and granites. Sm, $\mathrm{Nd}$, $\mathrm{Lu}$ and $\mathrm{Hf}$, the parent and daughter elements of the $\mathrm{Nd}$ and $\mathrm{Hf}$ isotopic systems, are all characterized by high field strengths, which confer them a significant degree of immobility during 
meteoric and metamorphic processes. Considering this, such clusters clearly suggest the existence of two somewhat distinct sources for the FCR-LAC anatectic complex, in agreement with the significant isotopic variability of the DBSG phyllites (Teixeira, 2008). Additionally, the fact that each of the clusters comprise metatexites, diatexites and granites suggests that during the metatexite-diatexite-granite evolution partial melting was not accompanied by significant isotopic disequilibrium, like those caused by the incomplete melting of zircon and the consequent variable release of zircon unradiogenic ${ }^{177} \mathrm{Hf}$ and non-zircon $\mathrm{Hf}$ during melting (the zircon effect; Tang et al., 2014). Considering the very long half-life of ${ }^{176} \mathrm{Lu}(37.1 \mathrm{Ga})$ and ${ }^{147} \mathrm{Sm}(106 \mathrm{Ga})$ and the lack of evidence for isotopic disequilibrium, protolith minerals must have had a comparatively short time period for developing distinct isotopic signatures. Alternatively, their isotopic compositions may have been homogenised during the highgrade metamorphism path preceding anatexis itself (Wolf et al., 2019). The occurrence of restricted isotopic disequilibrium during the first melting stages that led to the formation of the metatexites should not be discarded. However, given the natural isotopic variability of the probable source rocks (e.g. Teixeira, 2008) the most likely explanation for the isotopic variability in the migmatite-granites is source heterogeneity. Below we will focus on the metatexite-diatexite-granite compositional transitions.

It should be noticed that the present-day values $\left(\varepsilon_{0}\right)$ show a distinct behaviour for the isotope systems in consideration. Indeed, inside of each of the two groups, enclosing metatexites/diatexites/granites, a significantly larger variation is observed for the $\mathrm{\varepsilon Hf}_{0}$ values than for $\varepsilon \mathrm{Nd}_{0}$ (Fig. 14a). Considering this and the fact that in the $\varepsilon \mathrm{Hf}_{320}$ vs. $\varepsilon \mathrm{Nd}_{320}$ diagram (Fig. 9c) two clusters are observed comprising granites and migmatites, we propose that a significant fractionation between $\mathrm{Hf}$ and $\mathrm{Nd}$ isotopic systems occurred during melting reactions from metatexites to diatexites and finally to granites, caused by a distinct behaviour of their parent/daughter pairs. As shown before (6.3), the melting process involved essentially micas and plagioclase, phases with no capability to significantly fractionate $\mathrm{Sm}$ from $\mathrm{Nd}$ or $\mathrm{Lu}$ from $\mathrm{Hf}$, thus suggesting the role 
621 of an accessory phase to explain this different behaviour. Apatite in peraluminous 622 systems has $D^{\mathrm{Sm} / \mathrm{Nd}} \approx 0.3$ and and $\mathrm{D}^{\mathrm{Lu} / \mathrm{Hf}} \approx 70$ (Bea et al., 1994), making it a good 623 candidate. However, $\varepsilon \mathrm{Nd}_{0}$ of granite-metatexite pairs is similar or only slightly varying, 624 which would not be expected, and apatite dissolution during melting reactions would 625 induce an increase of ${ }^{176} \mathrm{Hf} /{ }^{177} \mathrm{Hf}$ by radiogenic ingrowth of ${ }^{176} \mathrm{Hf}$ with time, opposite to 626 what it is observed.. Therefore, decoupling of Lu and Hf cannot be attributed to apatite dissolution. The observed decoupling of $\mathrm{Hf}$ and $\mathrm{Nd}$ isotopic systems can be achieved by the involvement of zircon. Zirconium and $\mathrm{Hf}$ are usually considered as two geochemically coherent elements, which explains the very high $D_{H f}$ characterizing zircon $\left(D_{\mathrm{Hf}} \approx 2420\right.$; Wang et al., 2010). The consequent very low Lu/Hf ratios characterizing zircon will allow, that by incomplete melting of zircon, $\mathrm{Lu} / \mathrm{Hf}$ in the melt to be distinct of that of the whole source rock, and that granites would evolve with time to lower ${ }^{176} \mathrm{Hf} /{ }^{177} \mathrm{Hf}$ ratios than the less evolved metatexites. Moreover, variable zircon contribution to melt will contribute to the production of liquid batches characterized by significantly different $\mathrm{Lu} / \mathrm{Hf}$ ratios. This would be facilitated by incomplete zircon dissolution, a process which has been demonstrated to frequently occur in peraluminous granitic magmas where zircon saturation occurs at relatively low $\mathrm{Zr}$ concentrations ( 78 ppm; Harrison and Watson, 1983; Hogan and Sinha, 1991; Tang et al., 2014) and, also, by the fact that zircon is preferentially located inside biotite which can protect it from dissolution (Bea, 1996) (see also 6.4). In opposition to the observed for Lu/Hf ratios, zircon only have a limited capability to fractionate $\mathrm{Sm}$ from $\mathrm{Nd}\left(\mathrm{D}_{\mathrm{Sm} / \mathrm{Nd}} \approx 1\right.$; Bea et al 1994), thus explaining the contrasting behaviour of $\mathrm{Hf}$ and $\mathrm{Nd}$ present day isotope ratios depicted on Fig. 14a).

644 Each of the FCR-LAC metatexite/diatexite/granite groups defined on the $\varepsilon \mathrm{Hf}_{320} \mathrm{vs}$. $645 \varepsilon \mathrm{Nd}_{320}$ diagram (Fig. 9c) display a significant present-day ${ }^{87} \mathrm{Sr} /{ }^{86} \mathrm{Sr}$ range at almost 646 constant $\varepsilon N d$ (Fig. 14b). This suggests that Sr isotope signatures evolved under distinct 647 
and $\mathrm{Hf}$ systems, which are mainly controlled by the solubility of accessory phases, in the $\mathrm{Rb} / \mathrm{Sr}$ system the melt composition is constrained by the major mineral phases involved in the melting reactions (Tang et al., 2014; Wolf et al., 2019). In fact, an increase of $\left({ }^{87} \mathrm{Sr} /{ }^{86} \mathrm{Sr}\right)_{0}$ from metatexites to diatexites and then to granites is observed (Fig. 14b), which indicates an increase of ${ }^{87} \mathrm{Rb} /{ }^{86} \mathrm{Sr}$ in the melts progressively generated at higher temperatures. If we take into account the melting reactions inferred for the FCR-LAC (as in section 6.3), it is expected firstly a significant contribution of muscovite to the melt (reactions 1 and 2) and later a minor contribution of biotite, a mineral usually characterized by significantly higher $\mathrm{Rb} / \mathrm{Sr}$ than coexisting muscovite (e.g. Neiva et al., 2002), which together can explain these isotopic ranges and evolutions.

Nonetheless, the range in $\mathrm{Sr}$ isotopes is observed even when the initial values $\left({ }^{87} \mathrm{Sr} /{ }^{86} \mathrm{Sr}\right)_{320}$ are considered (Fig. 9a). There are several ways to explain variation on the initial $\mathrm{Sr}$ isotopic composition: isotopic disequilibrium, hydrothermal alteration, assimilation/fractional crystallization (AFC), and source heterogeneity.

Isotopic disequilibrium taking place during the melting stages involving various minerals characterized by significantly distinct ${ }^{87} \mathrm{Rb} /{ }^{86} \mathrm{Sr}$ (plagioclase, muscovite, biotite) is a plausible mechanism, especially in these settings (crustal anatexis). However, these isotopic signatures had to be developed previously to melting to account for variable mineral ${ }^{87} \mathrm{Sr} /{ }^{86} \mathrm{Sr}$ during radiogenic ingrowth (Farina and Stevens, 2011; Zeng et al., 2005b). Yet, at odds with the commonly observed in situations of isotopic disequilibrium (e.g. Wolf et al., 2019), no systematic isotopic variation is observed when considered the different lithotypes (metatexites, diatexites, and granites), but only a significant overlapping of the ${ }^{87} \mathrm{Sr}^{86} \mathrm{Sr}_{320}$ characterizing metatexites and granites. In this perspective, the ${ }^{87} \mathrm{Sr}^{86} \mathrm{Sr}_{320}$ variability could likely just be the result

673 of open-system processes, such as hydrothermal alteration and/or 674 assimilation/fractional crystallization (AFC). A hydrothermal overprint on these units would result in a lack of correlation between mobile and high field strength immobile 
676 elements, such as LILE and Ti, respectively (e.g. Huang et al., 2019). This is not 677 supported by our data, which show a clearly linear correlation between $\mathrm{K}, \mathrm{Sr}, \mathrm{Ba}$ vs. $678 \mathrm{TiO}_{2}$ (Fig. 15a-c). Therefore, ${ }^{87} \mathrm{Sr}^{86} \mathrm{Sr}_{320}$ variability as a result of post-magmatic 679 overprint is not plausible.

680 AFC is not a very probable process in constraining the chemical variability of S-type granitic systems (Clemens and Stevens, 2012; Yakymchuk, 2019). Indeed, as suggested by Castro (2014), the small difference in density between melt and minerals precociously crystallised, as well as the high viscosity of high silica melts, lead to consider as probably small and inefficient the role of fractional crystallization on granitic

685 686 magmas. In addition, it has been considered, based on thermodynamics, that granitic melts have a limited capability of assimilation of crustal rocks, which is more evident for relatively low-temperature S-type magmas like those in this study (e.g. Glazner, 2007). In agreement, no positive correlation is observed for the studied rocks between $\mathrm{La} / \mathrm{Sm}$ and Th/Sc (Fig. 15d), both ratios being expected to increase during AFC processes (Huang et al., 2019).

Given the lack of evidence for $\mathrm{Sr}$ isotopic disequilibrium and for the occurrence of hydrothermal alteration or AFC processes, the large variability of the ${ }^{87} \mathrm{Sr}^{86} \mathrm{Sr}_{320}$ was most probably caused by source heterogeneity. This is in agreement with geochemical studies of the DBSG phyllites which have shown a much larger heterogeneity of the $\mathrm{Sr}$ isotope ratios than the observed for ${ }^{143} \mathrm{Nd} /{ }^{144} \mathrm{Nd}$ (Teixeira, 2008), and in line with Clemens and Stevens (2012) and Yakymchuk (2019) findings, who concluded that source heterogeneity is an important factor on isotopic variations in granites in as much it controls the type of peritectic minerals that will form.

On the ${ }^{207} \mathrm{~Pb} /{ }^{204} \mathrm{~Pb}$ vs ${ }^{206} \mathrm{~Pb} /{ }^{204} \mathrm{~Pb}$ diagram (Fig. 14c), the studied rocks define a linear array close to the evolution line modelled for the upper continental crust by Zartman and Doe (1981). However, a significantly larger dispersion is observed in the ${ }^{208} \mathrm{~Pb} /{ }^{204} \mathrm{~Pb}$ vs. ${ }^{206} \mathrm{~Pb} /{ }^{204} \mathrm{~Pb}$ (Fig. 14d and Fig. 10b), suggesting decoupling of ${ }^{206} \mathrm{~Pb}$ and ${ }^{207} \mathrm{~Pb}$ (the final products of the decay chains of ${ }^{238} \mathrm{U}$ and ${ }^{235} \mathrm{U}$, respectively) from ${ }^{208} \mathrm{~Pb}$, 
704 the final radiogenic product of ${ }^{232} \mathrm{Th}$. In granitic systems, the elemental $\mathrm{Pb}$ budget is mainly controlled by K-feldspar, whereas accessory phases are the main repositories of $U$ and Th (e.g. Bea, 1996), which have the ability to strongly influence the long-term lead isotope evolution (Hogan and Sinha, 1991; Wolf et al., 2019). Decoupling of uranogenic lead from thorogenic lead (Fig. 10b) may then reflect the variable modal proportions of these phases in the source materials and also the variable contribution to melts of U-rich (e.g.: zircon, apatite and monazite) and Th-rich (e.g.: monazite and apatite) minerals.

\subsection{Source rocks: some considerations}

Based on the whole-rock geochemistry (e.g. Harker diagrams; Fig. 4 and 5), we can distinguish the geochemical evolution due to partial melting and the progressive residuum-melt separation, with the metapelitic rocks (phyllites) plotting at the origin of the metatexite-diatexite-granite sequence. This relationship is in clear agreement with field-based observations (as seen in section 3).

Despite the isotopic differences/variability between the phyllite $\mathrm{N}$ and phyllite $\mathrm{S}$ (Douro-Beiras Supergroup; Fig. 9b; Teixeira, 2008), and even among the anatectic complex lithologies, the $\mathrm{Sr}, \mathrm{Nd}$, and $\mathrm{Hf}$ isotopic compositions show a clear affinity between migmatites and phyllites. This is more evident for the phyllite $\mathrm{N}$ sample with $\mathrm{Sr}$ and Nd signatures within the range of the FCR-LAC units (Fig. 9a and Table 5), than for the phyllite $\mathrm{S}$ sample, where only the $\mathrm{Hf}$ initial composition is within analytical uncertainty of the remaining anatectic units (Fig. 9c and Table 5). $\mathrm{TDM}_{2}$ provenance ages of the metasedimentary protoliths of the anatectic complex broadly agree with the phyllite units $\mathrm{TDM}_{2}$ ages (Table 5), which reinforces the Douro-Beiras Supergroup as representing the most probable protolith.

While we can not go too far beyond out current small dataset to draw further links between a definitive source to this anatectic complex (either phyllite $\mathrm{N}$ or phyllite $\mathrm{S}$ ), it 
seems reasonable to propose a stronger affinity with the Douro Group, sampled to the N. However, we cannot fully discard the involvement of the southern Beiras Group units (Tassinari et al., 1996) nor a minor contribution from the Ollo de Sapo magmatic rocks (Montero et al., 2017), particularly when the $\mathrm{Nd}$ initial isotopic compositions are taken into account (Fig. 9b). This is particularly the case of the Ily late-tectonic granite, which exhibits isotopic compositions significantly different from the syn-tectonic granites (Fig. 9a and 9c; see Ferreira et al., 2019 for granite ages).

The contrasting $\mathrm{Nd}$ and $\mathrm{Hf}$ isotopic results between phyllites sampled from the northern $\left(\varepsilon \mathrm{Nd}_{320}=-10.07\right)$ and southern $\left(\varepsilon \mathrm{Nd}_{320}=+3.28\right)$ domains are striking, but in agreement with previously published data for the CIZ metasediments (Villaseca et al. (2014). This suggests source heterogeneities between both domains, with variable detrital inputs (more and less evolved crustal sources), which influenced the isotopic composition of the FCR-LAC units.

Further work is needed to clearly demonstrate: a) a systematic isotopic variability between the metasedimentary units to the North and South of the FCR-LAC; and b) the affinity of the anatectic complex with the Douro Group. This will further elucidate if the JPCSZ was a major paleogeographic boundary during the Precambrian/Cambrian, as proposed by Villaseca et al. (2014) and Iglesias and Ribeiro (1981).

7. Conclusions

This study shows the links between the distinct lithologies of the variscan Figueira de Castelo Rodrigo - Lumbrales Anatectic Complex of the Central Iberian Zone and evaluates the occurrence of isotopic disequilibrium during melting reactions from metatexites to diatexites and granites. The main conclusions are summarized below:

1) Based on whole-rock elemental and isotopic geochemistry a genetic link is definitively established between metatexites, diatexites and granites, which represent different evolutionary stages of the anatectic complex, culminating on the genesis of the S-type granites. 
2) We demonstrate the existence of two geochemically distinct diatexite groups (type-1 and type-2) generated at different stages of the partial melting process. We show that type-1 diatexite, with high $\mathrm{Rb}$ concentration and fractionated HREE is geochemically similar to the regional S-type granites, whereas type-2 diatexites are not linked to any of the outcropping granites.

3) Based on the mineral assemblage and whole-rock geochemistry we demonstrated that type-1 diatexites-and granites were produced during dehydration-melting of muscovite and production of peritectic K-feldspar and sillimanite plus melt. On the contrary, Rb-poor, unfractionated HREE type-2 diatexites required influx of externally derived fluids during melting, which consumed more plagioclase than muscovite. The type-2 diatexites represent a more evolved melt composition than the outcropping granites, being mainly composed by quartz and feldspar.

4) Evidence of incipient biotite melting and Ti-in-zircon thermometry allow to establish peak temperatures ranging from 783 to $836 \stackrel{\circ}{\mathrm{C}}$. These conditions resulted in the production of large volumes of melt, which explains the profusion of S-type granites within the ClZ.

5) There are no signs of significant isotopic disequilibrium during melting in the transition from metatexites to diatexites and, finally, to granites. This means that the source minerals were in isotopic equilibrium at the onset of the melting process, either reflecting that they were formed shortly before melting, or, alternatively, that isotopic homogenization during the high-grade metamorphism preceding the melting process took place. However, the distinct contributions of mineral phases to the melt produced batches of melt with distinct parent/daughters' ratios, which resulted in distinct radiogenic ingrowth, and explain the present-day isotopic heterogeneity found in these units.

6) $\mathrm{Rb} / \mathrm{Sr}$ ratios and the $\mathrm{Pb}$ budget of the successively generated lithotypes were mainly controlled by major minerals such as muscovite, K-feldspar and 
plagioclase. The accessory phases were the main minerals controlling the $\mathrm{Sm} / \mathrm{Nd}, \mathrm{Lu} / \mathrm{Hf}$ ratios and the $\mathrm{U}$ and Th contents.

7) Two distinct groups, both comprising metatexites, diatexites and granites, were identified when comparing the initial isotopic ratios, testifying for the existence of source heterogeneity. This is consistent with the isotopic variability of metasediments considered to be the sources of the anatectic complex and may also explain the differences in the initial $\mathrm{Hf}$ and $\mathrm{Nd}$ isotopic compositions between late-tectonic granite-migmatite cluster and the syn-tectonic granitemigmatite cluster.

8) The genetic links with probable protoliths of the anatectic complex were also explored. We showed that anatectic complex is sourced on the Neoproterozoic/Lower Cambrian Douro-Beiras Supergroup, with possible minor contribution of the Ordovician Ollo de Sapo magmatic rocks.

Acknowledgements: The corresponding author thanks the financial support of Fundação para a Ciência e Tecnologia (FCT) through a doctoral grant (PD/BD/114486/2016). The authors would also like to acknowledge the financial support of FCT through project UIDB/50019/2020 - IDL. Inês Pereira acknowledges a PhD bursary awarded by the University of Portsmouth. We would also like to thank the University of Portsmouth for the access to their analytical facilities, including sample preparation, SEM and LA-ICP-MS instruments. We also acknowledge Editor Marco Scambelluri, Chris Yakymchuk and Bruna Carvalho for their important inputs to this article.

\section{References}

Alves Ribeiro, J., Monteiro-Santos, F.A., Pereira, M.F., Díez Fernández, R., Dias da Silva, Í., Nascimento, C., Silva, J.B., 2017. Magnetotelluric imaging of the 
lithosphere across the Variscan Orogen (Iberian autochthonous domain, NW Iberia). Tectonics. https://doi.org/10.1002/2017TC004593

Areias, M., Ribeiro, M.A., Santos, J.F., Dória, A., 2014. LP-HT anatectic processes and lithological heterogeneity in the Mindelo Migmatite Complex (NW Portugal). Estud. Geológicos 70, 1-20. https://doi.org/10.3989/egeol.41730.323

Ayres, M., Harris, N., 1997. REE fractionation and Nd-isotope disequilibrium during crustal anatexis: constraints from Himalayan leucogranites. Chem. Geol. 139, 249-269. https://doi.org/10.1016/S0009-2541(97)00038-7

Barbero, L., Villaseca, C., Rogers, G., Brown, P.E., 1995. Geochemical and isotopic disequilibrium in crustal melting: an insight from the anatectic granitoids from Toledo, Spain. J. Geophys. Res. 100. https://doi.org/10.1029/95jb00036

Bea, F., 1996a. Residence of REE, Y, Th and U in granites and crustal protoliths; implications for the chemistry of crustal melts. J. Petrol. 37, 521-552. https://doi.org/10.1093/petrology/37.3.521

Bea, F., 1996b. Controls on the trace element composition of crustal melts. Trans. R. Soc. Edinb. Earth Sci. 87, 33-41. https://doi.org/10.1017/S0263593300006453

Bea, F., Pereira, M.D., Stroh, A., 1994. Mineral/leucosome trace-element partitioning in a peraluminous migmatite (a laser ablation-ICP-MS study). Chem. Geol. 117, 291-312. https://doi.org/10.1016/0009-2541(94)90133-3

Bento dos Santos, T., Rodrigues, J.F., Castro, P., Meireles, C., Ferreira, N., Ferreira, P., Ferreira, J.A., Pereira, I., Ribeiro, A., Pereira, E., Guimarães, F., n.d. Exhumation of an anatectic complex by channel flow and extrusion tectonics: structural and metamorphic evidence from the Porto - Viseu Metamorphic Belt, Central-Iberian Zone. Int. J. Earth Sci.

Bento dos Santos, T.M., Munhá, J.M., Tassinari, C.C.G., Fonseca, P.E., 2011a. The 
link between partial melting, granitization and granulite development in central Ribeira Fold Belt, SE Brazil: New evidence from elemental and Sr-Nd isotopic geochemistry. J. South Am. Earth Sci. 31, 262-278. https://doi.org/10.1016/j.jsames.2011.01.004

Bento dos Santos, T.M., Munhá, J.M., Tassinari, C.C.G., Fonseca, P.E., Neto, C.D., 2011b. Metamorphic P-T evolution of granulites in the central Ribeira Fold Belt, SE Brazil. Geosci. J. 15, 27-51. https://doi.org/10.1007/s12303-011-0004-1

Blichert-Toft, J., Albarède, F., 1997. The Lu-Hf isotope geochemistry of chondrites and the evolution of the mantle-crust system. Earth Planet. Sci. Lett. 148, 243-258. https://doi.org/https://doi.org/10.1016/S0012-821X(97)00040-X

Brown, C.R., Yakymchuk, C., Brown, M., Fanning, C.M., Korhonen, F.J., Piccoli, P.M., Siddoway, C.S., 2016. From source to sink: Petrogenesis of cretaceous anatectic granites from the Fosdick migmatite-granite complex, West Antarctica. J. Petrol. 57, 1241-1278. https://doi.org/10.1093/petrology/egw039

Brown, M., 2013. Granite: From genesis to emplacement. Bull. Geol. Soc. Am. 125, 1079-1113. https://doi.org/10.1130/B30877.1

Bucher, K., Grapes, R., 2011. Petrogenesis of Metamorphic Rocks 8th Edition, Journal of Chemical Information and Modeling. https://doi.org/10.1007/978-3-540-74169-5

Burg, J.-P., Van den Driessche, J., Brun, J.-P., 1994. Syn-to post-thickening extension in the Variscan Belt of Western Europe: Modes and structural consequences. Géologie la Fr. 3, 33-51.

Carríngton da Costa, J., Teixeira, C., 1957. Carta Geológica de Portugal, na escala 1/50.000, Notícia Explicativa da Folha 9-C. Serviços Geológicos Port. 39 pp.

Castro, A., 2014. The off-crust origin of granite batholiths. Geosci. Front. 5, 63-75. https://doi.org/10.1016/J.GSF.2013.06.006 
863 Chappell, B.W., White, A.J.R., 2001. Two contrasting granite types: 25 years later. Aust. J. Earth Sci. 48, 489-499.

865 866

867 868

Chappell, B.W., White, A.J.R., 1974. Two contrasting granite types. Pacific Geol. 8, 173-174.

Chauvel, C., Garçon, M., Bureau, S., Besnault, A., Jahn, B., Ding, Z., 2014. Constraints from loess on the $\mathrm{Hf}-\mathrm{Nd}$ isotopic composition of the upper continental crust. Earth Planet. Sci. Lett. 388, 48-58. https://doi.org/10.1016/j.epsl.2013.11.045

Clemens, J., 2006. Melting of the continental crust: Fluid regimes, melting reactions, and source-rock fertility, Evolution and Differentiation of the Continental Crust.

Clemens, J.D., Stevens, G., 2012. What controls chemical variation in granitic magmas? Lithos 134-135, 317-329. https://doi.org/10.1016/j.lithos.2012.01.001

Clemens, J.D., Vielzeuf, D., 1987. Constraints on melting and magma production in the crust. Earth Planet. Sci. Lett. 86, 287-306. https://doi.org/10.1016/0012$821 \times(87) 90227-5$

Costa, M.M., Neiva, A.M.R., Azevedo, M.R., Corfu, F., 2014. Distinct sources for syntectonic Variscan granitoids: Insights from the Aguiar da Beira region, Central Portugal. Lithos 196-197, 83-98. https://doi.org/10.1016/j.lithos.2014.02.023

Davies, G.R., Tommasini, S., 2000. Isotopic disequilibrium during rapid crustal anatexis: Implications for petrogenetic studies of magmatic processes. Chem. Geol. 162, 169-191. https://doi.org/10.1016/S0009-2541(99)00123-0

Dias, R., Ribeiro, A., 1995. The Ibero-Armorican Arc: A collision effect against an irregular continent? Tectonophysics 246, 113-128. https://doi.org/10.1016/00401951(94)00253-6

Dias, R., Ribeiro, A., Romão, J., Coke, C., Moreira, N., 2016. A review of the arcuate structures in the lberian Variscides; constraints and genetic models. 
Díez Fernández, R., Pereira, M.F., 2016. Extensional orogenic collapse captured by strike-slip tectonics: Constraints from structural geology and $\mathrm{U}[\mathrm{sbnd}] \mathrm{Pb}$ geochronology of the Pinhel shear zone (Variscan orogen, Iberian Massif). Tectonophysics 691, 290-310. https://doi.org/10.1016/j.tecto.2016.10.023

Dou, J., Siebel, W., He, J., Chen, F., 2019. Different melting conditions and petrogenesis of peraluminous granites in western Qinling, China, and tectonic implications. Lithos 336-337, 97-111. https://doi.org/10.1016/j.lithos.2019.04.003

Esteves, A.F., 2006. As rochas metamórficas da região de Viseu. University of Aveiro.

Farina, F., Stevens, G., 2011. Lithos Source controlled 87 Sr / 86 Sr isotope variability in granitic magmas: The inevitable consequence of mineral-scale isotopic disequilibrium in the protolith. LITHOS 122, 189-200. https://doi.org/10.1016/j.lithos.2011.01.001

Ferreira, J.A., Bento dos Santos, T., Pereira, I., Mata, J., 2019. Tectonically assisted exhumation and cooling of Variscan granites in an anatectic complex of the Central Iberian Zone , Portugal : constraints from LA - ICP - MS zircon and apatite U - Pb ages. Int. J. Earth Sci. https://doi.org/10.1007/s00531-019-01755-1

Ferreira, J.A., Ribeiro, M.A., Martins, H.C.B., 2014. The Pedregal granite (Portugal): petrographic and geochemical characterization of a peculiar granitoid. Estud. Geológicos 70, e019. https://doi.org/10.3989/egeol.41730.321

Frost, B.R., Calvin, G.B., William, J.C., Arculus, R.J., Ellis, D.J., Frost, C.D., 2001. A Geochemical Classification for Granitic Rocks. J. Petrol. 42, 2033-2048.

Gao, L.E., Zeng, L., Asimow, P.D., 2017. Contrasting geochemical signatures of fluidabsent versus fluid-fluxed melting of muscovite in metasedimentary sources: The Himalayan leucogranites. Geology 45. https://doi.org/10.1130/G38336.1 
913 Griffin, W.L., Wang, X., Jackson, S.E., Pearson, N.J., O’Reilly, S.Y., Xu, X., Zhou, X., 914 2002. Zircon chemistry and magma mixing, SE China: In-situ analysis of $\mathrm{Hf}$ 915 isotopes, Tonglu and Pingtan igneous complexes. Lithos 61, 237-269.

916 https://doi.org/https://doi.org/10.1016/S0024-4937(02)00082-8

917 Hart, S.R., Blusztajn, J., Dick, H.J.B., Meyer, P.S., Muehlenbachs, K., 1999. The 918 fingerprint of seawater circulation in a 500-meter section of ocean crust gabbros. 919 Geochim. Cosmochim. Acta 63, 4059-4080. https://doi.org/10.1016/S00167037(99)00309-9.

Henrichs, I.A., O’Sullivan, G., Chew, D.M., Mark, C., Babechuk, M.G., McKenna, C., Emo, R., 2018. The trace element and U-Pb systematics of metamorphic apatite. Chem. Geol. 483, 218-238. https://doi.org/10.1016/j.chemgeo.2017.12.031

Iglesias, M., Ribeiro, A., 1981. La zone de cisaillement ductile de Juzbado (Salamanca)-Penalva Do Castelo (Viseu): un linéament ancien réactivé pendant l'orogénese hercynienne? Comun. dos Serviços Geológicos Port. 67(1), 89-93.

Inger, S., Harris, N., 1993. Geochemical Constraints on Leukogranite Magmatism in the Langtang Valley, Nepal Himalaya. J. Petrol. 34, 345-368. https://doi.org/10.1093/petrology/34.2.345

Jacobsen, S.B., Wasserburg, G.J., 1980. Sm-Nd isotopic evolution of chondrites. Earth Planet. Sci. Lett. 50, 139-155. https://doi.org/https://doi.org/10.1016/0012$821 \times(80) 90125-9$

Johannes, W., Ehlers, C., Kriegsman, L.M., Mengel, K., 2003. The link between migmatites and S-type granites in the Turku area, southern Finland. Lithos 68, 69-90. https://doi.org/10.1016/S0024-4937(03)00032-X

Jung, S., 2005. Isotopic equilibrium/disequilibrium in granites, metasedimentary rocks and migmatites (Damara orogen, Namibia) - A consequence of 
polymetamorphism and melting. Lithos $84,168-184$.

Jung, S., Pfänder, J.A., 2007. Source composition and melting temperatures of orogenic granitoids: constraints from $\mathrm{CaO} / \mathrm{Na} 2 \mathrm{O}, \mathrm{Al} 2 \mathrm{O} 3 / \mathrm{TiO} 2$ and accessory mineral saturation thermometry. Eur. J. Mineral. 19, 859-870. https://doi.org/10.1127/0935-1221/2007/0019-1774

Liew, T., Hofmann, A., 1988. Precambrian crustal components, plutonic associations, plate environment of the Hercynian Fold Belt of central Europe: Indications from a $\mathrm{Nd}$ and Sr isotopic study. Contrib. to Mineral. Petrol. 98, 129-138. https://doi.org/10.1007/BF00402106

Lugmair, G.W., Marti, K., 1978. Lunar initial 143Nd/144Nd: Differential evolution of the lunar crust and mantle. Earth Planet. Sci. Lett. 39, 349-357. https://doi.org/https://doi.org/10.1016/0012-821X(78)90021-3

Martínez Catalán, J.R., Rubio Pascual, F.J., Montes, A.D., Fernández, R.D., Barreiro, J.G., Dias Da Silva, Í., Clavijo, E.G., Ayarza, P., Alcock, J.E., 2014. The late Variscan HT/LP metamorphic event in NW and Central lberia: relationships to crustal thickening, extension, orocline development and crustal evolution. Geol. Soc. London, Spec. Publ. 405, 225-247. https://doi.org/10.1144/SP405.1

Martini, A., Fátima, M. De, Weinberg, R.F., Betino, G., Toni, D., Nardi, L.V.S., 2019. From migmatite to magma - crustal melting and generation of granite in the Camboriú Complex , south Brazil. Lithos 340-341, 270-286. https://doi.org/10.1016/j.lithos.2019.05.017

Miller, C.F., McDowell, S.M., Mapes, R.W., 2003. Hot and cold granites: Implications of zircon saturation temperatures and preservation of inheritance. Geology 31, 529_ 532. https://doi.org/10.1130/0091-7613(2003)031<0529:HACGIO>2.0.CO;2 
Milord, I., Sawyer, E.W., Brown, M., 2001. Formation of diatexite migmatite and granite magma during anatexis of semi-pelitic metasedimentary rocks: An example from St. Malo, France. J. Petrol. 42, 487-505. https://doi.org/10.1093/petrology/42.3.487

Montero, P., Talavera, C., Bea, F., 2017. Geochemical, isotopic, and zircon (U-Pb, O, $\mathrm{Hf}$ isotopes) evidence for the magmatic sources of the volcano-plutonic Ollo de Sapo Formation, Central Iberia. Geol. Acta 15, 245-260. https://doi.org/10.1344/GeologicaActa2017.15.4.1

Morfin, S., Sawyer, E.W., Bandyayera, D., 2014. The geochemical signature of a felsic injection complex in the continental crust: Opinaca Subprovince, Quebec. Lithos 196-197, 339-355. https://doi.org/10.1016/j.lithos.2014.03.004

Nance, R.D., Gutiérrez-Alonso, G., Keppie, J.D., Linnemann, U., Murphy, J.B., Quesada, C., Strachan, R.A., Woodcock, N.H., 2010. Evolution of the Rheic Ocean. Gondwana Res. 17, 194-222. https://doi.org/10.1016/j.gr.2009.08.001

Palme, H., O'Neil, H.S.C., 2003. Cosmochemical estimatess of mantle composition. mantle core 2, 1-38. https://doi.org/10.1016/B978-0-08-095975-7.00201-1

Patiño Douce, A.E., Harris, N., 1998. Experimental Constraints on Himalayan Anatexis. J. Petrol. 39, 689-710. https://doi.org/10.1093/petroj/39.4.689

Pereira, I., Dias, R., Bento dos Santos, T., Mata, J., 2017. Exhumation of a migmatite complex along a transpressive shear zone: Inferences from the Variscan JuzbadoPenalva do Castelo Shear Zone (Central Iberian Zone). J. Geol. Soc. London. 174, 1004-1018. https://doi.org/10.1144/jgs2016-159

Perini, G., Cesare, B., Gömez-Pugnaire, M.T., Ghezzi, L., Tommasini, S., 2009. Armouring effect on Sr-Nd isotopes during disequilibrium crustal melting: the case study of frozen migmatites from El Hoyazo and Mazarrón, SE Spain. Eur. J. 
Ribeiro, M.A., Sant'Ovaia, H., Dória, A., 2011. Litologias gnaisso-migmatíticas da faixa Lavadores-Madalena: possível significado das paragéneses com hercinite. Simpósio Model. Sist. Geológicos 343-351.

Ribeiro, M.L., 1978. Algumas observações sobre o metamorfismo na região de Tourém (N de Portugal). Serviços Geológicos Port. 151-169.

Rosenberg, C.L., Handy, M.R., 2005. Experimental deformation of partially melted granite revisited: implications for the continental crust. J. Metamorph. Geol. 23, 19-28. https://doi.org/10.1111/j.1525-1314.2005.00555.x

Sawyer, E.W., 2008. Atlas of Migmatites. NRC Research Press and Mineralogical Association of Canada. https://doi.org/doi:10.1139/9780660197876

Sawyer, E.W., 1987. The role of partial melting and fractinal crystallization determining discordant migmatites leucosome compositions. J. Petrol. 28, 445-473.

Sawyer, E.W., Cesare, B., Brown, M., 2011. When the continental crust melts. Elements 7, 229-234. https://doi.org/10.2113/gselements.7.4.229

Schulmann, K., Schaltegger, U., Jezek, J., Thompson, A.B., Edel, J.B., 2002. Rapid burial and exhumation during orogeny: Thickening and synconvergent exhumation of thermally weakened and thinned crust (Variscan Orogen in Western Europe). Am. J. Sci. 302, 856-879. https://doi.org/10.2475/ajs.302.10.856

Silva, A., Ribeiro, M.L., 2000. Carta Geológica Simplificada do Parque Arqueológico do Vale do Côa. Vila Nova de Foz Côa.

Söderlund, U., Patchett, P.J., Vervoort, J., Isachsen, C., 2004. The 176Lu decay constant determined by $\mathrm{Lu}-\mathrm{Hf}$ and $\mathrm{U}-\mathrm{Pb}$ isotope systematics of Precambrian mafic intrusions. Earth Planet. Sci. Lett. 219, 311-324. https://doi.org/10.1016/S0012$821 \times(04) 00012-3$ 
Sola, A.M., Becchio, R.A., Pimentel, M.M., 2013. Petrogenesis of migmatites and leucogranites from Sierra de Molinos, Salta, Northwest Argentina: A petrologic and geochemical study Lithos Petrogenesis of migmatites and leucogranites from Sierra de Molinos, Salta , Northwest Argentina : A petrologic . LITHOS 177, 470491. https://doi.org/10.1016/j.lithos.2013.07.025

Spear, F.S., Kohn, M.J., Cheney, J.T., 1999. P - T paths from anatectic pelites. Contrib. to Mineral. Petrol. 134, 17-32. https://doi.org/10.1007/s004100050466

Steiger, R.H., Jäger, E., 1977. Subcommission on geochronology: Convention on the use of decay constants in geo- and cosmochronology. Earth Planet. Sci. Lett. 36, 359-362. https://doi.org/https://doi.org/10.1016/0012-821X(77)90060-7

Tang, M., Wang, X., Shu, X., Wang, D., Yang, T., Gopon, P., 2014. Hafnium isotopic heterogeneity in zircons from granitic rocks : Geochemical evaluation and modeling of " zircon effect" in crustal anatexis. Earth Planet. Sci. Lett. 389, 188199. https://doi.org/10.1016/j.epsl.2013.12.036

Tassinari, C.C.G., Medina, J., Pinto, M.S., 1996. Rb-Sr and Sm-Nd geochronology and isotope geochemistry of central Iberian metasedimentary rocks (Portugal). Geol. en Mijnb. 75, 69-79.

Teixeira, R.J.S., 2008. Mineralogia, petrologia e geoquímica dos granitos e seus encraves da região de Carrazeda de Ansiães. Universidade de Trás-os-Montes e Alto Douro.

Tommasini, S., Davies, G.R., 1997. Isotope disequilibrium during anatexis: a case study of contact melting, Sierra Nevada, California. Earth Planet. Sci. Lett. 148, 273-285.

Trail, D., Watson, E., Tailby, N., 2012. Ce and Eu anomalies in zircon as proxies for oxidation state of magmas. Geochim. Cosmochim. Acta 97, 70-87. 
Tuttle, O.F., Bowen, N.L., 1958. Origin of granite in the light of experimental studies in the system NaAlSi3O8-KAISi3O8-SiO2-H2O, Geological Society of America Memoir.

1042

1043

1044

1045

1046

1047

1048

1049

1050

1051

1052

1053

1054

1055

1056

1057

1058

1059

1060

1061

1062

Vanderhaeghe, O., 2009. Migmatites, granites and orogeny: Flow modes of partiallymolten rocks and magmas associated with melt/solid segregation in orogenic belts. Tectonophysics 477, 119-134. https://doi.org/10.1016/j.tecto.2009.06.021

Vernon, R.H., Clarke, G.L., 2008. Principles of metamorphic petrology. Cambridge University Press.

Vervoort, J.D., Blichert-Toft, J., 1999. Evolution of the depleted mantle: Hafnium isotope evidence from juvenile rocks through time. Igca 63, 533-556. https://doi.org/10.1016/S0016-7037(98)00274-9

Vielzeuf, D., Holloway, J., 1988. Experimental determination of the fluid-absent melting relations in the pelitic system. Contrib. to Mineral. Petrol. 98, 257-276. https://doi.org/10.1007/BF00375178

Villar Alonso, P., Fernández Ruiz, J., Bellido, F., Carrasco, R.., Rodriguez Fernández, L.., 2000. Memoria del mapa geológico de España 1:50000, Lumbrales (Hoja 475). Série magna, $1^{\mathrm{a} e d,} 2^{\mathrm{a}}$ série,. Madrid.

Villaros, A., Stevens, G., Moyen, J.F., Buick, I.S., 2009. The trace element compositions of S-type granites: Evidence for disequilibrium melting and accessory phase entrainment in the source. Contrib. to Mineral. Petrol. 158, 543561. https://doi.org/10.1007/s00410-009-0396-3

Villaseca, C., Barbero, L., Herreros, V., 1998. A re-examination of the typology of peraluminous granite types in intracontinental orogenic belts. Trans. R. Soc. Edinb. Earth Sci. 89, 113-119. https://doi.org/DOI: 10.1017/S0263593300007045 
1063

1064

1065

1066

1067

1068

1069

1070

1071

1072

1073

1074

1075

1076

1077

1078

1079

1080

1081

1082

1083

1084

1085

1086

1087

Villaseca, C., Merino, E., Oyarzun, R., Orejana, D., Pérez-Soba, C., Chicharro, E., 2014. Contrasting chemical and isotopic signatures from Neoproterozoic metasedimentary rocks in the Central Iberian Zone (Spain) of pre-Variscan Europe: Implications for terrane analysis and Early Ordovician magmatic belts. Precambrian Res. 245, 131-145. https://doi.org/10.1016/j.precamres.2014.02.006

Wang, X., Griffin, W.L., Chen, J., 2010. Hf contents and Zr/Hf ratios in granitic zircons. Geochem. J. 44, 65-72. https://doi.org/10.2343/geochemj.1.0043

Watson, E.B., Harrison, T.M., 1983. Zircon saturation revisited: temperature and composition effects in a variety of crustal magma types. Earth Planet. Sci. Lett. 64, 295-304. https://doi.org/10.1016/0012-821X(83)90211-X

Weinberg, R.F., Hasalová, P., 2015. Water-fluxed melting of the continental crust: A review. Lithos. https://doi.org/10.1016/j.lithos.2014.08.021

White, W., 2010. Oceanic Island Basalts and Mantle Plumes: The Geochemical Perspective. Annu. Rev. Earth Planet. Sci 38, 133-160. https://doi.org/10.1146/annurev-earth-040809-152450

Whitney, D.L., Teyssier, C., Vanderhaeghe, O., 2004. Gneiss domes and crustal flow. Spec. Pap. 380 Gneiss Domes Orogeny 15-33. https://doi.org/10.1130/0-81372380-9.15

Winter, J.D., 2014. Principles of Igneous and Metamorphic Petrology John D. Winter Second Edition.

Wolf, M., Romer, R.L., Glodny, J., 2019. Isotope disequilibrium during partial melting of metasedimentary rocks. Geochim. Cosmochim. Acta 257, 163-183. https://doi.org/10.1016/j.gca.2019.05.008

Yakymchuk, C., 2019. On Granites. J. Geol. Soc. India 94, 9-22. https://doi.org/10.1007/s12594-019-1261-2 
Yakymchuk, C., Acosta-Vigil, A., 2019. Geochemistry of phosphorus and the behavior of apatite during crustal anatexis: Insights from melt inclusions and nanogranitoids. Am. Mineral. 104, 1765-1780. https://doi.org/10.2138/am-20197054

Yakymchuk, C., Brown, C.R., Brown, M., Siddoway, C.S., Fanning, C.M., Korhonen, F.J., 2015. Paleozoic evolution of western Marie Byrd Land, Antarctica. Bull. Geol. Soc. Am. 127, 1464-1484. https://doi.org/10.1130/B31136.1

Yakymchuk, C., Brown, M., 2014. Consequences of open-system melting in tectonics. J. Geol. Soc. London. 171, 21-40. https://doi.org/10.1144/jgs2013-039

Yakymchuk, C., Clark, C., White, R.W., 2017. Phase Relations, Reaction Sequences and Petrochronology. Rev. Mineral. Geochemistry 83, 13-53. https://doi.org/10.2138/rmg.2017.83.2

Yakymchuk, C., Siddoway, C.S., Fanning, C.M., Mcfadden, R., Korhonen, F.J., Brown, M., 2013. Anatectic reworking and differentiation of continental crust along the active margin of Gondwana: A zircon $\mathrm{Hf}-\mathrm{O}$ perspective from West Antarctica. Geol. Soc. Spec. Publ. 383, 169-210. https://doi.org/10.1144/SP383.7

Yang, L., Liu, X.-C., Wang, J.-M., Wu, F.-Y., 2019. Is Himalayan leucogranite a product by in situ partial melting of the Greater Himalayan Crystalline? A comparative study of leucosome and leucogranite from Nyalam, southern Tibet. Lithos 342343, 542-556.

Zartman, R.E., Doe, B.R., 1981. Plumbotectonics - the model. Tectonophysics 75, 135-162.

Zeng, L., Asimow, P.D., Saleeby, J.B., 2005a. Coupling of anatectic reactions and dissolution of accessory phases and the $\mathrm{Sr}$ and $\mathrm{Nd}$ isotope systematics of anatectic melts from a metasedimentary source. Geochim. Cosmochim. Acta 69, 
Zeng, L., Saleeby, Æ.J.B., Ducea, Æ.M., 2005b. Geochemical characteristics of crustal anatexis during the formation of migmatite at the Southern Sierra Nevada , California. https://doi.org/10.1007/s00410-005-0010-2

Figure Captions

Fig.1 - (a) Figueira de Castelo Rodrigo-Lumbrales Anatectic Complex in the Iberian Variscan Belt setting (adapted from Dias et al., 2016); (b) Geological map of the Figueira de Castelo Rodrigo-Lumbrales Anatectic Complex (modified from Silva and Ribeiro, 2000).

Fig. 2 - Field observations: (a) phyllites with andalusite porphyroblasts; (b) metatexite with bands of peritectic sillimanite; (c) metatexite with boudinated leucosome veins; (d) leucosome pocket associated to metatexite; (e) restitic nodule in diatexite; (f) schlieren structures in diatexite; (g) nebulitic texture in diatexite; (h) and (i) two-mica granites with variable grain size.

Fig. 3 - Petrographic observations: (a) phyllite with foliated texture; (b) pseudomorph of andalusite in the phyllite; (c) alternation of leucosome and melanosome in the metatexite; (d) fibrolite included in the retrograde secondary muscovite in metatexite; (e) Corroded biotite and melt films evidences (red arrows) in diatexite; (f) secondary muscovite including fibrolite in diatexite; (g) granite texture and typical mineralogy; (h) granite with evidences of deformation.

Fig. 4 - Harker diagrams for major elements for the host rocks (phyllites and quartzphyllites) and FCR-LAC lithologies (metatexites, diatexites and granites).

Fig. 5 - Harker diagrams for trace elements for the host rocks (phyllites and quartzphyllites) and FCR-LAC lithologies (metatexites, diatexites and granites). 
1137 Fig. 6 - (a) Multi-element diagram for phyllites, quartzphyllites and metatexites; (b)

1138 Multi-element diagram for type-1 diatexites, type-2 diatexites and granites. Chondrite 1139 normalization values after Palme and O’Neil (2003).

1140 Fig. 7 - (a) REE diagram for phyllites, quartzphyllites and metatexites; (b) REE 1141 diagram for type-1 diatexites and type-2 diatexites; (c) REE diagram for granites. 1142 Chondrite normalization values after Palme and O'Neil (2003).

1143 Fig. 8 - (a), (b), (c), (d) and (e) Sr, Y, Th, U and REE (ppm) versus SiO2 WR (Whole1144 Rock; wt. \%), respectively; (f) Apatite REE pattern for phyllites, quartzphyllites, 1145 metatexites, type-1 diatexites, type-2 diatexites and granites; (g) Zircon REE pattern for 1146 metatexites, type-1 diatexites, type-2 diatexites and granites. Chondrite normalization 1147 values after Palme and O’Neil (2003).

1148 Fig. 9 - (a) ${ }^{87} \mathrm{Sr}^{86} \mathrm{Sr}_{320}$ versus $\varepsilon \mathrm{Nd}_{320}$ diagram for the host rocks (phyllites) and FCR1149 LAC lithologies (metatexites, diatexites and granites); (b) ${ }^{87} \mathrm{Sr}^{86} \mathrm{Sr}_{320}$ versus $\varepsilon \mathrm{Nd}_{320}$ 1150 diagram for the host rocks (phyllites), FCR-LAC lithologies (metatexites, diatexites and 1151 granites) and comparison with other geological domains of the ClZ: Douro-Beiras 1152 Supergroup (Douro Group - Teixeira, 2008; Beiras Group - Tassinari et al., 1996; 1153 South CIZ - Villaseca et al., 2014), Aguiar da Beira granitoids (biotite granodiorite1154 granite and muscovite-biotite leucogranite; Costa et al., 2014), and Ollo de Sapo 1155 gneisses (Montero et al., 2017). The Aguiar da Beira granitoids were chosen because of its proximity to the FCR-LAC and their syn-tectonic character; (c) $\varepsilon \mathrm{Nd}_{320}$ versus $\varepsilon \mathrm{Hf}_{320}$ diagram for the host rocks (phyllites) and FCR-LAC lithologies (metatexites, diatexites and granites). The green and the purple ellipses correspond to groups defined by very close $\varepsilon \mathrm{Nd}_{320}$ vs. $\varepsilon \mathrm{Hf}_{320}$ compositions.

1160 Fig. $10-(\mathrm{a}){ }^{206} \mathrm{~Pb} /{ }^{204} \mathrm{~Pb}_{320}$ versus ${ }^{207} \mathrm{~Pb} /{ }^{204} \mathrm{~Pb}_{320}$ for the host rocks (phyllites) and FCR1161 LAC lithologies (metatexites, diatexites and granites);

(b) ${ }^{206} \mathrm{~Pb} /{ }^{204} \mathrm{~Pb}_{320}$ versus 
${ }^{208} \mathrm{~Pb} /{ }^{204} \mathrm{~Pb}_{320}$ for the host rocks (phyllites) and FCR-LAC lithologies (metatexites,

1163 diatexites and granites).

1164 Fig. 11 - (a) Aluminium Saturation Index (ASI) classification for granitic and diatexitic rocks proposed by (Frost et al., 2001); (b) A-B granite classification diagram of Villaseca et al. (1998); (c) Ab-Or-Q ternary diagram (Tuttle and Bowen, 1958; Winter, 2014) for the FCR-LAC granites; (d) $\mathrm{Na}_{2} \mathrm{O}+\mathrm{K}_{2} \mathrm{O}-\mathrm{CaO}$ (wt. \%) versus $\mathrm{SiO}_{2}$ (wt. \%) classification diagram (Frost et al., 2001) showing the ranges between alkalic and calcic composition for the FCR-LAC diatexites and granites.

1170 Fig. 12 - (a) $\mathrm{CaO} / \mathrm{Na}_{2} \mathrm{O}$ versus $\mathrm{Al}_{2} \mathrm{O}_{3} / \mathrm{TiO}_{2}$ (wt. \%) distinguish between pelite-derived melts $\left(\mathrm{CaO} / \mathrm{Na}_{2} \mathrm{O}<0.3\right)$ and melts derived from greywackes or igneous sources (Jung and Pfänder, 2007) for FCR-LAC granites and diatexites; (b) Rb/Sr versus Sr (ppm) and (c) $\mathrm{Rb} / \mathrm{Sr}$ versus $\mathrm{Ba}(\mathrm{ppm})$ for the host rocks (phyllites) and FCR-LAC lithologies (metatexites, diatexites and granites). The vectors represent the evolution of partial melting reactions (Inger and Harris, 1993): Mu(VP) - vapour-present muscovite melting; $\mathrm{Mu}(\mathrm{VA})$ - vapour-absent muscovite melting; $\mathrm{Bi}(\mathrm{VA})$ - vapour-absent biotite melting; (d) Cao (wt. \%) versus Eu/Eu* for the host rocks (phyllites) and FCR-LAC lithologies (metatexites, diatexites and granites).

Fig. 13 - Apatite and zircon role during the partial melting process in the FCR-LAC: (a) versus HREE (ppm).

Fig. $14-(a) \varepsilon \mathrm{Nd}_{0}$ versus $\varepsilon \mathrm{Hf}_{0}$ diagram for the host rocks (phyllites) and FCR-LAC lithologies (metatexites, diatexites and granites); (b) ${ }^{87} \mathrm{Sr}^{86} \mathrm{Sr}_{0}$ versus $\varepsilon \mathrm{Nd}_{0}$ diagram for the host rocks (phyllites) and FCR-LAC lithologies (metatexites, diatexites and granites); (b) and (c) Plumbotectonic model after Zartman and Doe (1981) applied to 1186 the host rocks (phyllites) and FCR-LAC lithologies (metatexites, diatexites and 1187 granites): A - mantle; B - orogene; C - upper crust; D - lower crust. 
1188 Fig. 15 - Covariation between LILE (K, Sr and Ba) and HFSE ( $\left.\mathrm{TiO}_{2}\right),(\mathrm{a})$, (b) and (c), 1189 respectively; (d) AFC assessment - La/Sm versus Th/Sc (ppm).

1190

1191 Table 1 - Modal mineralogical proportion for the host rocks (phyllites and 1192 quartzphyllites) and rocks from the Figueira de Castelo Rodrigo-Lumbrales Anatectic 1193 Complex (metatexites, diatexites and granites).

1194 Table 2 - Whole-rock chemical composition of phyllites, quartzphyllites (qtzphyllites) 1195 and FCR-LAC rocks (metatexites, diatexites, and granites). Major elements in weight 1196 percentage (wt. \%) and the trace elements expressed in parts per million (ppm).

1197 Table 3 - Apatite trace element composition (ppm) from the host rocks (phyllites) and 1198 FCR-LAC rocks (metatexites, diatexites, and granites).

1199 Table 4 - Zircon trace element composition (ppm) from FCR-LAC rocks (metatexites, 1200 diatexites, and granites).

1201 Table 5 - Whole-rock $\mathrm{Sr}, \mathrm{Nd}, \mathrm{Hf}$ and $\mathrm{Pb}$ isotopic data for the host rocks (phyllites) and 1202 FCR-LAC rocks (metatexites, diatexites, and granites). 
Table 1

\begin{tabular}{|c|c|c|c|c|c|c|}
\hline & Phyllites & Quartzphyllites & Metatexites & Type-1 Diatexites & Type-2 Diatexites & Granites \\
\hline Quartz & 36 & 48 & 32 & 32 & 40 & 33 \\
\hline Plagioclase & 10 & - & 14 & 22 & 28 & 23 \\
\hline K-feldspar & - & - & 7 & 12 & 14 & 17 \\
\hline Biotite & 30 & 30 & 22 & 9 & 8 & 12 \\
\hline Muscovite & 19 & 19 & 21 & 20 & 9 & 12 \\
\hline Sillimanite & - & - & 3 & 4 & $<1$ & 3 \\
\hline Chlorite & 4 & 2 & - & - & - & - \\
\hline Accessory minerals & $<1$ & $<1$ & $<1$ & $<1$ & $<1$ & $<1$ \\
\hline
\end{tabular}


Table 2

\begin{tabular}{|c|c|c|c|c|c|c|c|c|c|c|c|c|c|c|c|c|c|}
\hline Lithology & \multicolumn{2}{|c|}{ Phyllite $\mathrm{N}$} & \multicolumn{2}{|c|}{ Phyllite S } & Qtzphyllite N & Qtzphyllite S & \multicolumn{11}{|c|}{ Metatexite } \\
\hline Sample & JTJ-2 & JTJ-6 & JTJ-18 & JTJ-19 & JTJ-49 & JTJ-41b & JTJ-8 & JTJ-20 & JTJ-22B & JTJ-24B & JTJ-25 & JTJ-37 & JTJ-48B & JTJ-53 & JTJ-54B & JTJ-56A & JTJ-60A \\
\hline $\mathrm{SiO}_{2}$ & 61.02 & 54.64 & 63.82 & 66.63 & 68.39 & 65.71 & 58.57 & 66.85 & 63.74 & 74.73 & 60.94 & 69.23 & 59.31 & 64.82 & 58.51 & 69.93 & 71.14 \\
\hline $\mathrm{Al}_{2} \mathrm{O}_{3}$ & 18.02 & 23.40 & 17.68 & 14.94 & 14.18 & 16.15 & 20.42 & 16.58 & 17.78 & 12.47 & 18.57 & 15.08 & 18.69 & 15.58 & 20.42 & 14.10 & 15.38 \\
\hline $\mathrm{Fe}_{2} \mathrm{O}_{3}{ }^{\top}$ & 6.95 & 7.34 & 4.91 & 5.36 & 4.55 & 6.24 & 8.10 & 5.51 & 5.61 & 3.78 & 6.52 & 4.76 & 7.32 & 5.90 & 6.79 & 4.47 & 2.50 \\
\hline $\mathrm{FeO}^{\prime}$ & 6.25 & 6.60 & 4.42 & 4.82 & 4.09 & 5.61 & 7.29 & 4.96 & 5.05 & 3.40 & 5.87 & 4.28 & 6.59 & 5.31 & 6.11 & 4.02 & 2.25 \\
\hline $\mathrm{MnO}$ & 0.06 & 0.07 & 0.05 & 0.04 & 0.06 & 0.08 & 0.09 & 0.06 & 0.05 & 0.12 & 0.04 & 0.07 & 0.10 & 0.10 & 0.09 & 0.09 & 0.08 \\
\hline $\mathrm{MgO}$ & 2.40 & 2.06 & 1.75 & 1.67 & 1.65 & 2.00 & 2.43 & 1.74 & 2.01 & 1.25 & 2.24 & 1.84 & 2.70 & 2.16 & 2.73 & 1.69 & 0.73 \\
\hline $\mathrm{CaO}$ & 1.36 & 0.30 & 0.10 & 0.15 & 2.36 & 0.44 & 0.55 & 0.79 & 0.35 & 0.76 & 0.51 & 1.13 & 0.54 & 0.23 & 0.69 & 0.74 & 0.60 \\
\hline $\mathrm{Na}_{2} \mathrm{O}$ & 1.75 & 1.14 & 1.18 & 1.35 & 2.52 & 1.75 & 1.57 & 2.30 & 1.18 & 2.18 & 1.40 & 2.65 & 1.21 & 1.45 & 1.82 & 2.80 & 3.04 \\
\hline $\mathrm{K}_{2} \mathrm{O}$ & 3.40 & 4.49 & 4.34 & 2.86 & 3.68 & 3.03 & 3.92 & 3.48 & 3.84 & 3.41 & 4.16 & 3.27 & 4.42 & 2.84 & 3.67 & 3.41 & 4.34 \\
\hline $\mathrm{TiO}_{2}$ & 0.87 & 0.82 & 0.76 & 0.86 & 0.76 & 0.89 & 0.84 & 0.86 & 0.70 & 0.58 & 0.78 & 0.64 & 0.82 & 0.70 & 0.74 & 0.60 & 0.32 \\
\hline $\mathrm{P}_{2} \mathrm{O}_{5}$ & 0.14 & 0.13 & 0.11 & 0.07 & 0.15 & 0.15 & 0.13 & 0.11 & 0.14 & 0.17 & 0.17 & 0.19 & 0.15 & 0.14 & 0.17 & 0.16 & 0.24 \\
\hline LOI & 3.65 & 5.09 & 4.22 & 5.02 & 1.01 & 3.60 & 3.72 & 2.25 & 3.69 & 1.23 & 4.51 & 1.53 & 4.43 & 4.72 & 4.75 & 1.63 & 1.37 \\
\hline Total & 99.62 & 99.45 & 98.92 & 98.95 & 99.31 & 100.00 & 100.30 & 100.50 & 99.08 & 100.70 & 99.84 & 100.40 & 99.68 & 98.63 & 100.40 & 99.62 & 99.74 \\
\hline Sc & 15.00 & 18.00 & 15.00 & 14.00 & 11.00 & 15.00 & 18.00 & 15.00 & 15.00 & 8.00 & 16.00 & 12.00 & 17.00 & 15.00 & 17.00 & 13.00 & 7.00 \\
\hline $\mathrm{V}$ & 91.00 & 115.00 & 123.00 & 94.00 & 67.00 & 98.00 & 112.00 & 92.00 & 111.00 & 59.00 & 111.00 & 79.00 & 109.00 & 136.00 & 124.00 & 72.00 & 36.00 \\
\hline $\mathrm{Ba}$ & 737.00 & 780.00 & 764.00 & 608.00 & 660.00 & 608.00 & 735.00 & 497.00 & 615.00 & 683.00 & 921.00 & 664.00 & 738.00 & 1038.00 & 1005.00 & 361.00 & 286.00 \\
\hline $\mathrm{Sr}$ & 209.00 & 110.00 & 64.00 & 49.00 & 243.00 & 82.00 & 118.00 & 149.00 & 79.00 & 156.00 & 114.00 & 189.00 & 111.00 & 74.00 & 169.00 & 107.00 & 79.00 \\
\hline $\mathrm{Y}$ & 32.00 & 29.00 & 28.00 & 34.00 & 28.00 & 33.00 & 29.00 & 22.00 & 24.00 & 21.00 & 26.00 & 29.00 & 28.00 & 33.00 & 29.00 & 26.00 & 14.00 \\
\hline $\mathrm{Zr}$ & 203.00 & 133.00 & 211.00 & 218.00 & 386.00 & 285.00 & 142.00 & 188.00 & 162.00 & 274.00 & 142.00 & 200.00 & 140.00 & 155.00 & 140.00 & 240.00 & 114.00 \\
\hline $\mathrm{Cr}$ & 90.00 & 110.00 & 90.00 & 80.00 & 60.00 & 90.00 & 100.00 & 80.00 & 80.00 & 50.00 & 90.00 & 70.00 & 100.00 & 100.00 & 90.00 & 70.00 & 40.00 \\
\hline $\mathrm{Ni}$ & 40.00 & 40.00 & 20.00 & 30.00 & 20.00 & 20.00 & 50.00 & 30.00 & 20.00 & $<20$ & 30.00 & $<20$ & 40.00 & 50.00 & 30.00 & 30.00 & $<20$ \\
\hline $\mathrm{Ga}$ & 25.00 & 32.00 & 23.00 & 20.00 & 19.00 & 21.00 & 29.00 & 22.00 & 23.00 & 16.00 & 25.00 & 19.00 & 26.00 & 23.00 & 28.00 & 21.00 & 22.00 \\
\hline $\mathrm{Rb}$ & 154.00 & 184.00 & 174.00 & 116.00 & 154.00 & 110.00 & 189.00 & 167.00 & 180.00 & 186.00 & 170.00 & 150.00 & 234.00 & 170.00 & 281.00 & 279.00 & 260.00 \\
\hline $\mathrm{Nb}$ & 15.00 & 14.00 & 11.00 & 12.00 & 13.00 & 12.00 & 15.00 & 13.00 & 11.00 & 8.00 & 12.00 & 10.00 & 14.00 & 11.00 & 12.00 & 16.00 & 19.00 \\
\hline Cs & 4.90 & 9.90 & 7.60 & 4.80 & 8.80 & 2.10 & 16.30 & 12.60 & 33.30 & 20.60 & 9.30 & 9.40 & 28.50 & 13.30 & 44.10 & 58.40 & 42.00 \\
\hline $\mathrm{La}$ & 51.00 & 53.90 & 42.80 & 46.40 & 50.90 & 38.60 & 61.10 & 34.70 & 34.50 & 43.60 & 46.40 & 38.20 & 45.90 & 44.70 & 46.90 & 40.80 & 17.70 \\
\hline $\mathrm{Ce}$ & 92.40 & 104.00 & 83.00 & 93.20 & 103.00 & 77.60 & 114.00 & 73.00 & 69.20 & 91.10 & 92.10 & 78.50 & 90.60 & 88.30 & 92.80 & 82.70 & 35.00 \\
\hline $\mathrm{Pr}$ & 11.30 & 11.90 & 10.30 & 10.70 & 11.40 & 9.28 & 13.20 & 8.22 & 8.26 & 9.82 & 10.90 & 8.68 & 10.00 & 10.30 & 10.40 & 9.44 & 4.03 \\
\hline $\mathrm{Nd}$ & 40.10 & 43.30 & 37.90 & 40.80 & 41.60 & 34.30 & 46.60 & 31.00 & 30.00 & 35.50 & 40.90 & 31.60 & 37.50 & 38.40 & 38.40 & 34.00 & 14.00 \\
\hline $\mathrm{Sm}$ & 7.60 & 8.40 & 7.30 & 8.10 & 7.60 & 7.10 & 8.50 & 6.20 & 6.10 & 6.60 & 7.90 & 6.40 & 7.00 & 7.40 & 7.40 & 6.80 & 2.90 \\
\hline Eu & 1.55 & 1.69 & 1.41 & 1.65 & 1.67 & 1.42 & 1.67 & 1.23 & 1.22 & 1.10 & 1.50 & 1.36 & 1.39 & 1.47 & 1.53 & 1.10 & 0.54 \\
\hline $\mathrm{Gd}$ & 6.30 & 6.80 & 6.00 & 7.40 & 6.30 & 6.70 & 6.60 & 5.20 & 5.40 & 5.50 & 6.60 & 5.60 & 6.10 & 6.80 & 6.10 & 5.50 & 2.50 \\
\hline $\mathrm{Tb}$ & 1.00 & 1.00 & 0.90 & 1.20 & 1.00 & 1.10 & 1.00 & 0.80 & 0.90 & 0.80 & 1.00 & 0.90 & 1.00 & 1.00 & 1.00 & 0.90 & 0.50 \\
\hline Dy & 6.00 & 5.90 & 5.50 & 6.90 & 5.70 & 6.30 & 6.00 & 4.50 & 5.00 & 4.50 & 5.60 & 5.60 & 5.40 & 6.00 & 5.70 & 5.00 & 2.70 \\
\hline Ho & 1.10 & 1.10 & 1.10 & 1.30 & 1.10 & 1.20 & 1.10 & 0.80 & 0.90 & 0.80 & 1.00 & 1.10 & 1.00 & 1.20 & 1.10 & 1.00 & 0.50 \\
\hline $\mathrm{Er}$ & 3.30 & 3.20 & 3.10 & 3.70 & 3.10 & 3.70 & 3.10 & 2.50 & 2.80 & 2.30 & 2.90 & 3.40 & 3.00 & 3.40 & 3.10 & 2.80 & 1.40 \\
\hline $\mathrm{Tm}$ & 0.47 & 0.48 & 0.46 & 0.54 & 0.45 & 0.53 & 0.46 & 0.37 & 0.41 & 0.33 & 0.40 & 0.51 & 0.43 & 0.49 & 0.43 & 0.41 & 0.21 \\
\hline $\mathrm{Yb}$ & 3.10 & 3.20 & 3.10 & 3.50 & 3.10 & 3.50 & 2.90 & 2.60 & 2.90 & 2.20 & 2.70 & 3.40 & 2.90 & 3.20 & 2.90 & 2.80 & 1.40 \\
\hline $\mathrm{Lu}$ & 0.46 & 0.47 & 0.46 & 0.51 & 0.47 & 0.55 & 0.45 & 0.40 & 0.45 & 0.34 & 0.42 & 0.53 & 0.43 & 0.51 & 0.44 & 0.43 & 0.22 \\
\hline $\mathrm{Hf}$ & 5.40 & 3.60 & 5.20 & 5.50 & 9.30 & 7.00 & 3.70 & 4.80 & 4.20 & 6.00 & 3.50 & 5.00 & 3.80 & 3.80 & 3.80 & 6.10 & 2.80 \\
\hline $\mathrm{Ta}$ & 1.30 & 1.20 & 1.10 & 1.30 & 1.20 & 1.00 & 1.20 & 1.50 & 2.10 & 1.00 & 0.90 & 1.10 & 1.40 & 0.90 & 1.00 & 2.40 & 4.90 \\
\hline $\mathrm{Pb}$ & 23.00 & 21.00 & 10.00 & 11.00 & 22.00 & 15.00 & 25.00 & 20.00 & 17.00 & 28.00 & 21.00 & 29.00 & 22.00 & 22.00 & 25.00 & 17.00 & 21.00 \\
\hline Th & 17.10 & 16.90 & 12.00 & 10.20 & 16.70 & 13.40 & 17.20 & 10.80 & 10.50 & 15.30 & 12.70 & 11.90 & 13.20 & 12.20 & 13.20 & 12.80 & 5.50 \\
\hline$U$ & 3.50 & 6.50 & 3.60 & 3.80 & 3.20 & 3.80 & 4.20 & 5.10 & 6.60 & 3.50 & 4.50 & 3.90 & 6.40 & 43.70 & 9.40 & 7.10 & 3.80 \\
\hline REE & 225.68 & 245.34 & 203.33 & 225.90 & 237.39 & 191.88 & 266.68 & 171.52 & 168.04 & 204.49 & 220.32 & 185.78 & 212.65 & 213.17 & 218.20 & 193.68 & 83.60 \\
\hline
\end{tabular}




\begin{tabular}{|c|c|c|c|c|c|c|c|c|c|c|c|c|c|c|c|c|c|}
\hline LREE & 202.40 & 221.50 & 181.30 & 199.20 & 214.50 & 166.88 & 243.40 & 153.12 & 148.06 & 186.62 & 198.20 & 163.38 & 191.00 & 189.10 & 195.90 & 173.74 & 73.63 \\
\hline HREE & 23.28 & 23.84 & 22.03 & 26.70 & 22.89 & 25.00 & 23.28 & 18.40 & 19.98 & 17.87 & 22.12 & 22.40 & 21.65 & 24.07 & 22.30 & 19.94 & 9.97 \\
\hline LREE/HREE & 8.69 & 9.29 & 8.23 & 7.46 & 9.37 & 6.68 & 10.46 & 8.32 & 7.41 & 10.44 & 8.96 & 7.29 & 8.82 & 7.86 & 8.78 & 8.71 & 7.39 \\
\hline $\mathrm{La} / \mathrm{Yb}_{\mathrm{N}}$ & 11.08 & 11.34 & 9.30 & 8.93 & 11.06 & 7.43 & 14.19 & 8.99 & 8.01 & 13.35 & 11.57 & 7.57 & 10.66 & 9.41 & 10.89 & 9.81 & 8.51 \\
\hline $\mathrm{La} / \mathrm{Sm}_{\mathrm{N}}$ & 4.22 & 4.03 & 3.69 & 3.60 & 4.21 & 3.42 & 4.52 & 3.52 & 3.56 & 4.15 & 3.69 & 3.75 & 4.12 & 3.80 & 3.98 & 3.77 & 3.84 \\
\hline $\mathrm{Dy} / \mathrm{Yb}_{\mathrm{N}}$ & 1.26 & 1.20 & 1.15 & 1.28 & 1.19 & 1.17 & 1.34 & 1.12 & 1.12 & 1.33 & 1.35 & 1.07 & 1.21 & 1.22 & 1.28 & 1.16 & 1.25 \\
\hline $\mathrm{Tb} / \mathrm{Yb}_{\mathrm{N}}$ & 1.42 & 1.38 & 1.28 & 1.51 & 1.42 & 1.38 & 1.52 & 1.35 & 1.37 & 1.60 & 1.63 & 1.16 & 1.52 & 1.38 & 1.52 & 1.41 & 1.57 \\
\hline $\mathrm{Eu} / \mathrm{Eu}^{*}$ & 0.68 & 0.68 & 0.65 & 0.65 & 0.74 & 0.63 & 0.68 & 0.66 & 0.65 & 0.56 & 0.63 & 0.69 & 0.65 & 0.63 & 0.70 & 0.55 & 0.61 \\
\hline
\end{tabular}

Table 2 continued

\begin{tabular}{|c|c|c|c|c|c|c|c|c|c|c|c|c|c|c|c|c|}
\hline Lithology & \multicolumn{8}{|c|}{ Type-1 Diatexite } & \multicolumn{8}{|c|}{ Type-2 Diatexite } \\
\hline Sample & JTJ-27 & JTJ-30 & JTJ-31C & JTJ-43 & JTJ-48A & JTJ-52 & JTJ-55 & JPC-48 & JTJ-23A & JTJ-24A & JTJ-26 & JTJ-28A & JTJ-51 & JTJ-56B & JTJ-60B & JPC-45 \\
\hline $\mathrm{SiO} 2$ & 72.92 & 72.29 & 74.46 & 68.32 & 72.75 & 72.33 & 73.30 & 69.83 & 73.53 & 74.24 & 74.82 & 75.14 & 75.24 & 74.98 & 72.95 & 74.55 \\
\hline $\mathrm{Al} 2 \mathrm{O} 3$ & 13.92 & 14.17 & 14.07 & 15.60 & 15.37 & 14.94 & 14.72 & 15.62 & 14.35 & 13.93 & 13.27 & 14.96 & 12.87 & 12.91 & 15.25 & 14.11 \\
\hline $\mathrm{Fe} 2 \mathrm{O} 3^{1}$ & 0.97 & 1.38 & 0.90 & 2.90 & 1.29 & 1.52 & 1.13 & 2.15 & 1.12 & 0.75 & 0.81 & 0.18 & 2.67 & 1.01 & 0.98 & 0.81 \\
\hline $\mathrm{FeO}^{\prime}$ & 0.87 & 1.24 & 0.81 & 2.61 & 1.16 & 1.37 & 1.02 & 1.93 & 1.01 & 0.67 & 0.73 & 0.16 & 2.40 & 0.91 & 0.88 & 0.73 \\
\hline $\mathrm{MnO}$ & 0.01 & 0.01 & 0.02 & 0.03 & 0.03 & 0.02 & 0.03 & 0.03 & 0.03 & 0.03 & 0.01 & 0.01 & 0.05 & 0.03 & 0.02 & 0.02 \\
\hline $\mathrm{MgO}$ & 0.21 & 0.31 & 0.25 & 0.84 & 0.27 & 0.41 & 0.29 & 0.67 & 0.18 & 0.17 & 0.16 & 0.06 & 0.90 & 0.36 & 0.49 & 0.44 \\
\hline $\mathrm{CaO}$ & 0.59 & 0.63 & 0.54 & 0.95 & 0.61 & 0.74 & 0.88 & 0.62 & 0.46 & 0.59 & 0.60 & 0.42 & 0.65 & 0.48 & 0.44 & 0.21 \\
\hline $\mathrm{Na} 2 \mathrm{O}$ & 3.07 & 3.12 & 3.13 & 2.80 & 3.39 & 2.98 & 3.56 & 2.91 & 3.57 & 3.66 & 3.15 & 2.57 & 2.31 & 3.16 & 3.89 & 2.96 \\
\hline $\mathrm{K} 2 \mathrm{O}$ & 5.31 & 5.64 & 5.50 & 5.71 & 4.82 & 5.44 & 4.18 & 5.93 & 4.28 & 4.97 & 4.50 & 6.16 & 3.77 & 4.55 & 3.91 & 5.27 \\
\hline TiO2 & 0.12 & 0.20 & 0.13 & 0.75 & 0.19 & 0.24 & 0.15 & 0.40 & 0.07 & 0.07 & 0.11 & 0.02 & 0.39 & 0.12 & 0.10 & 0.12 \\
\hline P2O5 & 0.36 & 0.47 & 0.30 & 0.44 & 0.42 & 0.39 & 0.25 & 0.40 & 0.24 & 0.25 & 0.18 & 0.34 & 0.14 & 0.17 & 0.24 & 0.20 \\
\hline LOI & 1.10 & 0.93 & 0.83 & 1.41 & 1.05 & 1.15 & 1.21 & 1.23 & 1.35 & 0.72 & 0.98 & 0.81 & 1.47 & 1.50 & 1.20 & 1.19 \\
\hline Total & 98.58 & 99.14 & 100.10 & 99.74 & 100.20 & 100.20 & 99.68 & 101.72 & 99.18 & 99.38 & 98.58 & 100.70 & 100.50 & 99.25 & 99.46 & 100.61 \\
\hline Sc & 4.00 & 2.00 & 1.00 & 3.00 & 2.00 & 3.00 & 3.00 & $<7$ & 4.00 & 3.00 & 5.00 & $<1$ & 8.00 & 3.00 & 3.00 & $<7$ \\
\hline $\mathrm{V}$ & $<5$ & $<5$ & $<5$ & 29.00 & 6.00 & 8.00 & $<5$ & 13.00 & $<5$ & $<5$ & $<5$ & $<5$ & 38.00 & 9.00 & 9.00 & 5.00 \\
\hline $\mathrm{Ba}$ & 196.00 & 217.00 & 232.00 & 640.00 & 205.00 & 282.00 & 468.00 & 353.00 & 146.00 & 203.00 & 200.00 & 358.00 & 582.00 & 482.00 & 187.00 & 220.00 \\
\hline $\mathrm{Sr}$ & 57.00 & 56.00 & 61.00 & 150.00 & 50.00 & 74.00 & 139.00 & 89.00 & 43.00 & 79.00 & 63.00 & 111.00 & 128.00 & 115.00 & 69.00 & 82.00 \\
\hline $\mathrm{Y}$ & 12.00 & 11.00 & 4.00 & 11.00 & 8.00 & 12.00 & 9.00 & 14.00 & 9.00 & 8.00 & 12.00 & 4.00 & 24.00 & 9.00 & 7.00 & 10.00 \\
\hline $\mathrm{Zr}$ & 47.00 & 79.00 & 45.00 & 415.00 & 74.00 & 100.00 & 48.00 & 163.00 & 28.00 & 42.00 & 35.00 & 25.00 & 159.00 & 42.00 & 39.00 & 37.00 \\
\hline $\mathrm{Cr}$ & $<20$ & $<20$ & $<20$ & $<20$ & $<20$ & $<20$ & $<20$ & 19.00 & $<20$ & $<20$ & $<20$ & $<20$ & 40.00 & $<20$ & $<20$ & 6.00 \\
\hline $\mathrm{Ni}$ & $<20$ & $<20$ & $<20$ & $<20$ & $<20$ & $<20$ & $<20$ & 7.00 & $<20$ & $<20$ & $<20$ & $<20$ & $<20$ & $<20$ & $<20$ & $<7$ \\
\hline $\mathrm{Ga}$ & 18.00 & 21.00 & 19.00 & 26.00 & 24.00 & 20.00 & 17.00 & 23.00 & 16.00 & 12.00 & 16.00 & 17.00 & 16.00 & 12.00 & 15.00 & 14.00 \\
\hline $\mathrm{Rb}$ & 239.00 & 303.00 & 275.00 & 331.00 & 315.00 & 282.00 & 143.00 & 290.00 & 238.00 & 170.00 & 183.00 & 234.00 & 165.00 & 154.00 & 145.00 & 205.00 \\
\hline $\mathrm{Nb}$ & 6.00 & 7.00 & 4.00 & 6.00 & 10.00 & 7.00 & 6.00 & 10.37 & 9.00 & 4.00 & 3.00 & $<1$ & 7.00 & 5.00 & 5.00 & 4.98 \\
\hline Cs & 10.20 & 8.60 & 6.60 & 7.80 & 20.30 & 17.10 & 14.00 & & 34.80 & 9.70 & 5.00 & 6.00 & 10.10 & 8.60 & 6.00 & \\
\hline $\mathrm{La}$ & 7.20 & 15.60 & 5.90 & 145.00 & 14.70 & 20.40 & 21.00 & 36.96 & 3.50 & 3.60 & 4.60 & 1.10 & 36.60 & 7.70 & 6.80 & 3.79 \\
\hline $\mathrm{Ce}$ & 15.40 & 35.10 & 13.40 & 368.00 & 32.20 & 44.70 & 41.70 & 79.12 & 7.80 & 7.20 & 9.60 & 2.20 & 74.20 & 15.20 & 13.10 & 7.77 \\
\hline $\mathrm{Pr}$ & 1.85 & 4.23 & 1.65 & 46.50 & 3.78 & 5.19 & 4.80 & 9.79 & 0.88 & 0.79 & 1.11 & 0.28 & 8.21 & 1.64 & 1.49 & 0.95 \\
\hline $\mathrm{Nd}$ & 6.70 & 16.00 & 6.10 & 175.00 & 14.40 & 19.50 & 17.10 & 36.54 & 3.40 & 2.90 & 4.10 & 1.10 & 29.20 & 6.60 & 5.20 & 3.46 \\
\hline $\mathrm{Sm}$ & 1.80 & 4.10 & 1.80 & 25.40 & 3.90 & 5.10 & 4.10 & 8.99 & 0.80 & 0.70 & 1.10 & 0.40 & 5.90 & 1.30 & 1.00 & 0.98 \\
\hline $\mathrm{Eu}$ & 0.41 & 0.45 & 0.39 & 1.06 & 0.33 & 0.55 & 0.79 & 0.61 & 0.25 & 0.40 & 0.44 & 0.55 & 1.08 & 0.56 & 0.34 & 0.43 \\
\hline $\mathrm{Gd}$ & 1.90 & 3.60 & 1.80 & 9.50 & 3.50 & 4.70 & 3.30 & 6.86 & 1.00 & 0.80 & 1.30 & 0.50 & 4.80 & 1.30 & 0.90 & 1.12 \\
\hline $\mathrm{Tb}$ & 0.40 & 0.60 & 0.30 & 0.80 & 0.50 & 0.70 & 0.50 & 0.85 & 0.30 & 0.20 & 0.30 & 0.10 & 0.80 & 0.20 & 0.20 & 0.24 \\
\hline Dy & 2.40 & 2.90 & $\begin{array}{l}1.00 \\
.10\end{array}$ & 3.10 & 2.10 & 3.10 & 2.10 & $\begin{array}{l}3.05 \\
.52\end{array}$ & $\begin{array}{l}0.00 \\
1.70\end{array}$ & $\begin{array}{l}1.20 \\
1.30\end{array}$ & 2.00 & 0.60 & 4.70 & $\begin{array}{l}1.60 \\
1.40\end{array}$ & $\frac{.60}{1.10}$ & $\begin{array}{l}1.24 \\
1.70\end{array}$ \\
\hline
\end{tabular}




\begin{tabular}{|c|c|c|c|c|c|c|c|c|c|c|c|c|c|c|c|c|}
\hline $\mathrm{Ho}$ & 0.40 & 0.40 & 0.20 & 0.40 & 0.20 & 0.40 & 0.30 & 0.49 & 0.30 & 0.30 & 0.40 & 0.10 & 0.90 & 0.20 & 0.20 & 0.35 \\
\hline $\mathrm{Er}$ & 1.10 & 0.70 & 0.30 & 0.90 & 0.50 & 0.80 & 0.60 & 1.10 & 0.90 & 0.80 & 1.20 & 0.30 & 2.50 & 0.70 & 0.70 & 1.07 \\
\hline $\mathrm{Tm}$ & 0.14 & 0.08 & 0.05 & 0.12 & 0.06 & 0.11 & 0.08 & 0.15 & 0.14 & 0.14 & 0.20 & 0.05 & 0.37 & 0.10 & 0.11 & 0.18 \\
\hline $\mathrm{Yb}$ & 0.90 & 0.40 & 0.20 & 0.70 & 0.40 & 0.60 & 0.50 & 1.00 & 1.00 & 1.10 & 1.40 & 0.30 & 2.30 & 0.80 & 0.90 & 1.27 \\
\hline $\mathrm{Lu}$ & 0.12 & 0.01 & 0.01 & 0.09 & 0.05 & 0.10 & 0.06 & 0.14 & 0.15 & 0.17 & 0.22 & 0.04 & 0.36 & 0.13 & 0.13 & 0.20 \\
\hline $\mathrm{Hf}$ & 1.40 & 2.10 & 1.30 & 10.00 & 2.10 & 2.80 & 1.50 & 2.32 & 0.80 & 1.20 & 0.90 & 0.90 & 4.10 & 1.00 & 1.30 & $<0.06$ \\
\hline $\mathrm{Ta}$ & 0.70 & 0.80 & 0.60 & 0.50 & 1.90 & 0.90 & 1.10 & 1.03 & 1.90 & 1.30 & 0.30 & $<0.1$ & 0.90 & 1.00 & 1.40 & 0.37 \\
\hline $\mathrm{Pb}$ & 32.00 & 33.00 & 33.00 & 41.00 & 27.00 & 36.00 & 36.00 & 39.00 & 36.00 & 41.00 & 31.00 & 43.00 & 28.00 & 37.00 & 28.00 & 38.00 \\
\hline Th & 2.50 & 7.50 & 2.90 & 133.00 & 6.90 & 8.10 & 6.90 & 20.62 & 0.90 & 0.90 & 1.30 & $<0,1$ & 12.30 & 2.30 & 1.80 & 1.54 \\
\hline U & 5.50 & 9.30 & 6.10 & 10.30 & 10.00 & 7.80 & 5.90 & 13.48 & 6.80 & 12.80 & 3.30 & 1.50 & 5.40 & 3.00 & 7.10 & 3.38 \\
\hline REE & 40.52 & 84.17 & 33.20 & 776.57 & 76.62 & 105.95 & 96.93 & 186.13 & 22.12 & 20.40 & 27.97 & 7.62 & 171.92 & 37.83 & 32.17 & 23.52 \\
\hline LREE & 32.95 & 75.03 & 28.85 & 759.90 & 68.98 & 94.89 & 88.70 & 171.40 & 16.38 & 15.19 & 20.51 & 5.08 & 154.11 & 32.44 & 27.59 & 16.96 \\
\hline HREE & 7.57 & 9.14 & 4.35 & 16.67 & 7.64 & 11.06 & 8.23 & 14.73 & 5.74 & 5.21 & 7.46 & 2.54 & 17.81 & 5.39 & 4.58 & 6.57 \\
\hline LREE/HREE & 4.35 & 8.21 & 6.63 & 45.58 & 9.03 & 8.58 & 10.78 & 11.64 & 2.85 & 2.92 & 2.75 & 2.00 & 8.65 & 6.02 & 6.02 & 2.58 \\
\hline $\mathrm{La} / \mathrm{Yb}_{\mathrm{N}}$ & 5.39 & 26.27 & 19.87 & 139.50 & 24.75 & 22.90 & 28.29 & 24.80 & 2.36 & 2.20 & 2.21 & 2.47 & 10.72 & 6.48 & 5.09 & 2.01 \\
\hline $\mathrm{La} / \mathrm{Sm}_{\mathrm{N}}$ & 2.51 & 2.39 & 2.06 & 3.59 & 2.37 & 2.51 & 3.22 & 2.58 & 2.75 & 3.23 & 2.63 & 1.73 & 3.90 & 3.72 & 4.27 & 2.43 \\
\hline $\mathrm{Dy} / \mathrm{Yb}_{\mathrm{N}}$ & 1.59 & 4.71 & 3.57 & 2.88 & 3.41 & 3.36 & 2.73 & 2.28 & 1.10 & 0.77 & 0.93 & 1.30 & 1.33 & 1.14 & 0.79 & 0.87 \\
\hline $\mathrm{Tb} / \mathrm{Yb}_{\mathrm{N}}$ & 1.96 & 6.60 & 6.60 & 5.03 & 5.50 & 5.13 & 4.40 & 3.72 & 1.32 & 0.80 & 0.94 & 1.47 & 1.53 & 1.10 & 0.98 & 0.83 \\
\hline $\mathrm{Eu} / \mathrm{Eu}^{*}$ & 0.68 & 0.36 & 0.66 & 0.21 & 0.27 & 0.34 & 0.66 & 0.24 & 0.85 & 1.63 & 1.12 & 3.76 & 0.62 & 1.32 & 1.10 & 1.26 \\
\hline
\end{tabular}

Table 2 continued

\begin{tabular}{|c|c|c|c|c|c|c|c|c|c|c|c|c|c|c|c|c|}
\hline Lithology & \multicolumn{16}{|c|}{ Granite } \\
\hline Sample & JTJ-31A & JTJ-32 & JTJ-34 & JTJ-40 & JPC-49 & JPC-56 & JPC-57 & JTJ-9 & JTJ-10 & JTJ-44 & JTJ-45 & JTJ-47 & JTJ-50 & JTJ-62 & JPC-51 & JPC-52 \\
\hline $\mathrm{SiO} 2$ & 73.04 & 71.18 & 70.97 & 74.07 & 71.66 & 72.13 & 71.99 & 73.37 & 71.55 & 71.54 & 73.60 & 70.78 & 72.76 & 73.31 & 71.53 & 71.37 \\
\hline $\mathrm{Al} 2 \mathrm{O} 3$ & 15.07 & 14.88 & 15.14 & 14.33 & 14.95 & 14.88 & 15.02 & 14.56 & 14.70 & 15.20 & 14.40 & 14.89 & 14.50 & 15.40 & 14.92 & 15.19 \\
\hline $\mathrm{Fe}^{2 \mathrm{O} 3}$ & 1.04 & 1.91 & 2.36 & 0.51 & 1.94 & 1.56 & 1.50 & 1.28 & 1.45 & 1.56 & 1.36 & 1.90 & 1.32 & 0.92 & 1.48 & 1.41 \\
\hline $\mathrm{FeO}^{\prime}$ & 0.94 & 1.72 & 2.12 & 0.46 & 1.75 & 1.40 & 1.35 & 1.15 & 1.30 & 1.40 & 1.22 & 1.71 & 1.19 & 0.83 & 1.33 & 1.27 \\
\hline $\mathrm{MnO}$ & 0.02 & 0.03 & 0.02 & 0.01 & 0.02 & 0.02 & 0.02 & 0.02 & 0.03 & 0.02 & 0.02 & 0.03 & 0.03 & 0.04 & 0.02 & 0.02 \\
\hline $\mathrm{MgO}$ & 0.26 & 0.46 & 0.57 & 0.09 & 0.60 & 0.65 & 0.65 & 0.25 & 0.29 & 0.43 & 0.32 & 0.48 & 0.23 & 0.10 & 0.71 & 0.60 \\
\hline $\mathrm{CaO}$ & 0.55 & 0.71 & 0.88 & 0.34 & 0.45 & 0.36 & 0.36 & 0.53 & 0.62 & 0.60 & 0.55 & 0.71 & 0.57 & 0.44 & 0.34 & 0.33 \\
\hline $\mathrm{Na2O}$ & 2.90 & 2.51 & 2.61 & 1.99 & 2.67 & 3.14 & 3.03 & 2.98 & 3.30 & 3.04 & 2.79 & 2.83 & 3.15 & 3.92 & 3.87 & 3.04 \\
\hline $\mathrm{K} 2 \mathrm{O}$ & 5.24 & 5.43 & 5.98 & 7.57 & 5.61 & 5.38 & 5.54 & 4.99 & 5.02 & 5.34 & 5.28 & 5.56 & 5.01 & 4.05 & 5.47 & 6.09 \\
\hline TiO2 & 0.15 & 0.29 & 0.54 & 0.06 & 0.32 & 0.27 & 0.25 & 0.19 & 0.19 & 0.27 & 0.21 & 0.33 & 0.16 & 0.08 & 0.22 & 0.27 \\
\hline P2O5 & 0.38 & 0.48 & 0.41 & 0.55 & 0.33 & 0.37 & 0.39 & 0.36 & 0.40 & 0.44 & 0.41 & 0.35 & 0.35 & 0.45 & 0.38 & 0.33 \\
\hline LOI & 0.94 & 1.28 & 1.20 & 0.90 & 1.34 & 1.09 & 1.13 & 1.61 & 0.96 & 1.25 & 1.30 & 1.11 & 0.96 & 1.23 & 0.98 & 1.19 \\
\hline Total & 99.59 & 99.15 & 100.70 & 100.40 & 101.64 & 101.25 & 101.23 & 100.10 & 98.52 & 99.67 & 100.20 & 98.96 & 99.01 & 99.95 & 101.25 & 101.11 \\
\hline $\mathrm{Sc}$ & 1.00 & 3.00 & 2.00 & $<1$ & $<7$ & $<7$ & $<7$ & 2.00 & 2.00 & 2.00 & 3.00 & 2.00 & 2.00 & 2.00 & $<7$ & $<7$ \\
\hline $\mathrm{V}$ & 8.00 & 10.00 & 17.00 & $<5$ & 11.00 & 7.00 & 8.00 & 7.00 & 5.00 & 11.00 & 7.00 & 13.00 & $<5$ & $<5$ & 7.00 & 8.00 \\
\hline $\mathrm{Ba}$ & 211.00 & 279.00 & 357.00 & 143.00 & 258.00 & 235.00 & 217.00 & 243.00 & 225.00 & 262.00 & 206.00 & 263.00 & 139.00 & 46.00 & 213.00 & 261.00 \\
\hline $\mathrm{sr}$ & 60.00 & 68.00 & 84.00 & 54.00 & 69.00 & 67.00 & 62.00 & 57.00 & 57.00 & 64.00 & 54.00 & 80.00 & 48.00 & 27.00 & 62.00 & 79.00 \\
\hline Y & 5.00 & 17.00 & 10.00 & 9.00 & 12.00 & 10.00 & 12.00 & 7.00 & 7.00 & 10.00 & 7.00 & 7.00 & 6.00 & 6.00 & 10.00 & 9.00 \\
\hline $\mathrm{Zr}$ & 57.00 & 137.00 & 287.00 & 23.00 & 129.00 & 108.00 & 104.00 & 64.00 & 70.00 & 106.00 & 84.00 & 117.00 & 64.00 & 40.00 & 96.00 & 114.00 \\
\hline $\mathrm{Cr}$ & $<20$ & $<20$ & $<20$ & $<20$ & 8.00 & 8.00 & 7.00 & $<20$ & $<20$ & $<20$ & $<20$ & $<20$ & $<20$ & $<20$ & 5.00 & 5.00 \\
\hline $\mathrm{Ni}$ & $<20$ & $<20$ & $<20$ & $<20$ & $<7$ & $<7$ & $<7$ & $<20$ & $<20$ & $<20$ & $<20$ & $<20$ & $<20$ & $<20$ & $<7$ & $<7$ \\
\hline $\mathrm{Ga}$ & 23.00 & 24.00 & 27.00 & 22.00 & 22.00 & 22.00 & 22.00 & 22.00 & 22.00 & 22.00 & 22.00 & 27.00 & 23.00 & 26.00 & 20.00 & 23.00 \\
\hline $\mathrm{Rb}$ & 325.00 & 316.00 & 376.00 & 401.00 & 284.00 & 343.00 & 311.00 & 311.00 & 342.00 & 330.00 & 338.00 & 416.00 & 419.00 & 521.00 & 339.00 & 371.00 \\
\hline
\end{tabular}




\begin{tabular}{|c|c|c|c|c|c|c|c|c|c|c|c|c|c|c|c|c|}
\hline $\mathrm{Nb}$ & 5.00 & 9.00 & 7.00 & 3.00 & 10.54 & 11.26 & 11.68 & 9.00 & 9.00 & 7.00 & 9.00 & 9.00 & 14.00 & 15.00 & 10.08 & 8.87 \\
\hline Cs & 20.30 & 18.40 & 11.50 & 13.60 & & & & 13.30 & 27.00 & 15.20 & 18.90 & 17.80 & 26.60 & 37.50 & & \\
\hline $\mathrm{La}$ & 10.80 & 31.80 & 97.30 & 2.90 & 37.13 & 24.76 & 22.92 & 15.50 & 15.90 & 21.40 & 19.80 & 36.00 & 15.00 & 8.00 & 21.82 & 31.72 \\
\hline $\mathrm{Ce}$ & 25.00 & 75.50 & 248.00 & 7.80 & 85.76 & 54.74 & 52.13 & 34.00 & 34.60 & 50.80 & 47.50 & 84.10 & 34.10 & 17.90 & 50.56 & 71.00 \\
\hline $\mathrm{Pr}$ & 3.08 & 9.37 & 31.50 & 1.05 & 11.01 & 6.94 & 6.70 & 4.01 & 3.98 & 6.28 & 5.85 & 10.30 & 4.08 & 2.13 & 6.57 & 9.03 \\
\hline $\mathrm{Nd}$ & 12.40 & 35.40 & 119.00 & 4.30 & 41.49 & 26.35 & 25.79 & 14.80 & 15.20 & 24.10 & 22.40 & 38.50 & 14.50 & 7.80 & 25.37 & 34.11 \\
\hline $\mathrm{Sm}$ & 3.10 & 8.10 & 20.50 & 1.50 & 8.33 & 6.07 & 6.00 & 3.70 & 3.80 & 5.80 & 4.50 & 8.50 & 3.60 & 1.90 & 5.77 & 7.68 \\
\hline $\mathrm{Eu}$ & 0.41 & 0.54 & 0.78 & 0.33 & 0.42 & 0.42 & 0.40 & 0.34 & 0.36 & 0.51 & 0.38 & 0.62 & 0.33 & 0.13 & 0.37 & 0.54 \\
\hline $\mathrm{Gd}$ & 2.30 & 6.20 & 9.30 & 1.50 & 5.12 & 4.50 & 4.59 & 3.40 & 3.50 & 4.60 & 3.20 & 5.40 & 2.80 & 1.60 & 3.96 & 5.16 \\
\hline $\mathrm{Tb}$ & 0.30 & 0.90 & 0.80 & 0.30 & 0.63 & 0.54 & 0.63 & 0.50 & 0.50 & 0.60 & 0.40 & 0.60 & 0.40 & 0.30 & 0.51 & 0.58 \\
\hline Dy & 1.20 & 4.00 & 2.90 & 1.70 & 2.75 & 2.18 & 2.82 & 1.90 & 2.00 & 2.40 & 1.80 & 2.00 & 1.80 & 1.30 & 2.29 & 2.18 \\
\hline Ho & 0.20 & 0.60 & 0.30 & 0.30 & 0.39 & 0.29 & 0.38 & 0.20 & 0.20 & 0.30 & 0.20 & 0.20 & 0.20 & 0.20 & 0.32 & 0.29 \\
\hline Er & 0.40 & 1.30 & 0.70 & 0.70 & 0.84 & 0.58 & 0.78 & 0.40 & 0.40 & 0.60 & 0.60 & 0.60 & 0.50 & 0.50 & 0.70 & 0.56 \\
\hline $\mathrm{Tm}$ & 0.05 & 0.15 & 0.09 & 0.08 & 0.09 & 0.07 & 0.10 & 0.06 & 0.05 & 0.07 & 0.07 & 0.06 & 0.06 & 0.06 & 0.08 & 0.07 \\
\hline $\mathrm{Yb}$ & 0.30 & 0.80 & 0.50 & 0.50 & 0.60 & 0.38 & 0.55 & 0.30 & 0.30 & 0.40 & 0.40 & 0.30 & 0.30 & 0.40 & 0.47 & 0.43 \\
\hline $\mathrm{Lu}$ & 0.01 & 0.10 & 0.07 & 0.06 & 0.08 & 0.05 & 0.06 & 0.04 & 0.04 & 0.06 & 0.06 & 0.04 & 0.04 & 0.06 & 0.06 & 0.06 \\
\hline $\mathrm{Hf}$ & 1.50 & 3.70 & 7.00 & 1.00 & 1.55 & $<0.06$ & 1.50 & 1.70 & 1.90 & 2.80 & 2.20 & 3.10 & 1.80 & 1.50 & 1.31 & 3.02 \\
\hline $\mathrm{Ta}$ & 0.90 & 1.10 & 0.80 & 0.40 & 0.58 & 1.14 & 1.14 & 1.80 & 1.90 & 1.20 & 1.50 & 1.00 & 3.30 & 4.90 & 1.20 & 0.86 \\
\hline $\mathrm{Pb}$ & 28.00 & 36.00 & 39.00 & 43.00 & 38.00 & 35.00 & 35.00 & 27.00 & 27.00 & 31.00 & 29.00 & 36.00 & 32.00 & 16.00 & 36.00 & 43.00 \\
\hline Th & 6.80 & 22.20 & 107.00 & 1.20 & 39.25 & 22.16 & 20.21 & 6.90 & 7.20 & 13.90 & 15.60 & 28.50 & 9.10 & 5.10 & 20.86 & 33.69 \\
\hline$U$ & 6.70 & 12.60 & 10.70 & 3.50 & 16.30 & 11.93 & 14.03 & 5.10 & 9.40 & 8.70 & 11.10 & 15.00 & 13.70 & 4.50 & 10.69 & 5.84 \\
\hline REE & 59.55 & 174.76 & 531.74 & 23.02 & 194.63 & 127.86 & 123.85 & 79.15 & 80.83 & 117.92 & 107.16 & 187.22 & 77.71 & 42.28 & 118.85 & 163.41 \\
\hline LREE & 54.38 & 160.17 & 516.30 & 17.55 & 183.71 & 118.86 & 113.54 & 72.01 & 73.48 & 108.38 & 100.05 & 177.40 & 71.28 & 37.73 & 110.09 & 153.54 \\
\hline HREE & 5.17 & 14.59 & 15.44 & 5.47 & 10.92 & 9.00 & 10.31 & 7.14 & 7.35 & 9.54 & 7.11 & 9.82 & 6.43 & 4.55 & 8.76 & 9.88 \\
\hline LREE/HREE & 10.52 & 10.98 & 33.44 & 3.21 & 16.83 & 13.20 & 11.01 & 10.09 & 10.00 & 11.36 & 14.07 & 18.07 & 11.09 & 8.29 & 12.57 & 15.55 \\
\hline $\mathrm{La} / \mathrm{Yb}_{\mathrm{N}}$ & 24.24 & 26.77 & 131.06 & 3.91 & 41.48 & 43.79 & 27.82 & 34.80 & 35.69 & 36.03 & 33.34 & 80.82 & 33.67 & 13.47 & 31.35 & 49.25 \\
\hline $\mathrm{La} / \mathrm{Sm}_{\mathrm{N}}$ & 2.19 & 2.47 & 2.98 & 1.22 & 2.80 & 2.56 & 2.40 & 2.63 & 2.63 & 2.32 & 2.77 & 2.66 & 2.62 & 2.65 & 2.38 & 2.59 \\
\hline $\mathrm{Dy} / \mathrm{Yb}_{\mathrm{N}}$ & 2.60 & 3.25 & 3.77 & 2.21 & 2.96 & 3.72 & 3.30 & 4.11 & 4.33 & 3.90 & 2.92 & 4.33 & 3.90 & 2.11 & 3.18 & 3.27 \\
\hline $\mathrm{Tb} / \mathrm{Yb}_{\mathrm{N}}$ & 4.40 & 4.95 & 7.04 & 2.64 & 4.57 & 6.24 & 5.00 & 7.33 & 7.33 & 6.60 & 4.40 & 8.80 & 5.87 & 3.30 & 4.82 & 5.83 \\
\hline $\mathrm{Eu} / \mathrm{Eu}^{*}$ & 0.47 & 0.23 & 0.17 & 0.67 & 0.20 & 0.24 & 0.24 & 0.29 & 0.30 & 0.30 & 0.31 & 0.28 & 0.32 & 0.23 & 0.24 & 0.26 \\
\hline
\end{tabular}

Table 2 continued

\begin{tabular}{|c|c|c|c|c|c|c|c|c|c|c|c|c|c|c|}
\hline Lithology & \multicolumn{10}{|c|}{ Granite } \\
\hline Sample & JPC-53 & JTJ-35 & JPC-50 & JTJ-11 & JTJ-12 & JPC-55 & JTJ-59 & JTJ-13 & JPC-19 & JPC-24 & JPC-59 & JPC-54 & JTJ-36 & JTJ-58 \\
\hline SiO2 & 71.62 & 70.63 & 71.41 & 71.13 & 71.39 & 70.32 & 71.96 & 71.78 & 70.64 & 72.31 & 75.24 & 73.33 & 72.64 & 73.41 \\
\hline Al2O3 $^{1}$ & 15.20 & 15.10 & 15.05 & 14.71 & 15.01 & 15.51 & 14.50 & 14.60 & 15.15 & 14.64 & 13.95 & 14.72 & 14.91 & 14.81 \\
\hline $\mathrm{Fe}^{\prime} 23^{\prime}$ & 1.72 & 2.14 & 1.51 & 1.64 & 1.84 & 2.15 & 1.66 & 1.63 & 1.73 & 1.89 & 0.70 & 1.19 & 1.34 & 0.82 \\
\hline $\mathrm{FeO}$ & 1.55 & 1.93 & 1.36 & 1.48 & 1.66 & 1.93 & 1.49 & 1.47 & 1.56 & 1.70 & 0.63 & 1.07 & 1.21 & 0.74 \\
\hline $\mathrm{MnO}$ & 0.02 & 0.02 & 0.02 & 0.02 & 0.02 & 0.03 & 0.04 & 0.02 & 0.02 & 0.03 & 0.02 & 0.02 & 0.02 & 0.03 \\
\hline $\mathrm{MgO}$ & 0.70 & 0.59 & 0.55 & 0.43 & 0.41 & 0.75 & 0.54 & 0.36 & 0.63 & 0.64 & 0.36 & 0.48 & 0.31 & 0.19 \\
\hline $\mathrm{CaO}$ & 0.40 & 0.72 & 0.26 & 0.73 & 0.61 & 0.58 & 1.01 & 0.58 & 0.46 & 0.37 & 0.09 & 0.24 & 0.63 & 0.55 \\
\hline $\mathrm{Na2O}$ & 3.02 & 2.57 & 2.99 & 3.06 & 2.72 & 3.16 & 3.54 & 2.66 & 2.63 & 2.80 & 3.48 & 2.98 & 3.25 & 3.27 \\
\hline $\mathrm{K} 2 \mathrm{O}$ & 5.53 & 5.37 & 5.93 & 5.43 & 5.39 & 5.32 & 4.86 & 5.71 & 6.91 & 5.39 & 4.33 & 5.20 & 4.97 & 4.59 \\
\hline $\mathrm{TiO} 2$ & 0.31 & 0.44 & 0.22 & 0.28 & 0.28 & 0.42 & 0.28 & 0.28 & 0.40 & 0.31 & 0.10 & 0.19 & 0.19 & 0.10 \\
\hline $\mathrm{P} 2 \mathrm{O} 5$ & 0.37 & 0.48 & 0.47 & 0.37 & 0.40 & 0.39 & 0.29 & 0.49 & 0.31 & 0.36 & 0.30 & 0.30 & 0.44 & 0.35 \\
\hline $\mathrm{LOI}$ & 0.95 & 1.51 & 1.44 & 0.94 & 1.06 & 1.21 & 1.02 & 1.21 & 0.84 & 1.01 & 1.32 & 1.21 & 1.11 & 1.67 \\
\hline
\end{tabular}




\begin{tabular}{|c|c|c|c|c|c|c|c|c|c|c|c|c|c|c|}
\hline Total & 101.39 & 99.58 & 101.21 & 98.71 & 99.14 & 101.77 & 99.70 & 99.31 & 101.28 & 101.45 & 100.52 & 100.93 & 99.82 & 99.78 \\
\hline Sc & $<7$ & 3.00 & $<7$ & 2.00 & 2.00 & $<7$ & 3.00 & 2.00 & $<7$ & $<7$ & $<7$ & $<7$ & 2.00 & 3.00 \\
\hline $\mathrm{V}$ & 8.00 & 19.00 & $<5$ & 11.00 & 9.00 & 18.00 & 17.00 & 10.00 & 8.00 & 9.00 & $<5$ & 5.00 & 7.00 & $<5$ \\
\hline $\mathrm{Ba}$ & 240.00 & 376.00 & 183.00 & 283.00 & 235.00 & 287.00 & 491.00 & 268.00 & 407.00 & 172.00 & 134.00 & 146.00 & 274.00 & 201.00 \\
\hline $\mathrm{Sr}$ & 76.00 & 93.00 & 47.00 & 80.00 & 63.00 & 74.00 & 142.00 & 76.00 & 106.00 & 49.00 & 42.00 & 46.00 & 74.00 & 61.00 \\
\hline $\mathrm{Y}$ & 10.00 & 10.00 & 14.00 & 9.00 & 11.00 & 10.00 & 8.00 & 8.00 & 9.00 & 11.00 & 5.00 & 6.00 & 9.00 & 7.00 \\
\hline $\mathrm{Zr}$ & 123.00 & 211.00 & 86.00 & 112.00 & 116.00 & 198.00 & 130.00 & 113.00 & 193.00 & 130.00 & 35.00 & 72.00 & 74.00 & 46.00 \\
\hline $\mathrm{Cr}$ & 9.00 & $<20$ & 6.00 & $<20$ & $<20$ & 11.00 & $<20$ & $<20$ & 6.00 & 7.00 & $<5$ & 5.00 & $<20$ & $<20$ \\
\hline $\mathrm{Ni}$ & $<7$ & $<20$ & $<7$ & $<20$ & $<20$ & $<7$ & $<20$ & $<20$ & $<7$ & $<7$ & $<7$ & $<7$ & $<20$ & $<20$ \\
\hline $\mathrm{Ga}$ & 24.00 & 25.00 & 23.00 & 22.00 & 22.00 & 25.00 & 23.00 & 25.00 & 23.00 & 24.00 & 20.00 & 22.00 & 23.00 & 18.00 \\
\hline $\mathrm{Rb}$ & 371.00 & 358.00 & 403.00 & 334.00 & 357.00 & 369.00 & 276.00 & 381.00 & 305.00 & 378.00 & 277.00 & 293.00 & 288.00 & 281.00 \\
\hline $\mathrm{Nb}$ & 11.61 & 7.00 & 14.99 & 8.00 & 10.00 & 9.94 & 10.00 & 8.00 & 4.32 & 15.97 & 12.91 & $\begin{array}{l}7.92 \\
\end{array}$ & 10.00 & 9.00 \\
\hline Cs & & 10.60 & & 14.80 & 18.30 & & 19.10 & 13.00 & & & & & 17.00 & 18.90 \\
\hline $\mathrm{La}$ & 33.65 & 65.40 & 16.95 & 26.60 & 30.40 & 64.65 & 38.80 & 31.20 & 61.40 & 37.77 & 5.03 & 14.98 & 12.40 & 8.50 \\
\hline $\mathrm{Ce}$ & 75.62 & 162.00 & 39.29 & 60.00 & 72.70 & 151.70 & 77.60 & 72.00 & 135.11 & 87.83 & 11.04 & 33.71 & 26.90 & 17.70 \\
\hline $\mathrm{Pr}$ & 9.74 & 20.40 & 5.00 & 7.08 & 8.82 & 19.91 & 8.80 & 8.88 & 16.41 & 11.35 & 1.36 & 4.24 & 3.27 & 2.09 \\
\hline $\mathrm{Nd}$ & 36.91 & 75.60 & 18.49 & 26.50 & 33.50 & 75.41 & 30.80 & 33.80 & 61.23 & 43.58 & 5.09 & 15.65 & 12.40 & 7.50 \\
\hline $\mathrm{Sm}$ & 8.17 & 12.90 & 3.94 & 6.30 & 7.00 & 12.56 & 5.50 & 7.40 & 13.18 & 9.40 & 1.22 & 3.56 & 3.30 & 2.20 \\
\hline $\mathrm{Eu}$ & 0.50 & 0.74 & 0.25 & 0.57 & 0.45 & 0.59 & 0.75 & 0.56 & 0.79 & 0.46 & 0.11 & 0.23 & 0.34 & 0.51 \\
\hline $\mathrm{Gd}$ & 5.30 & 6.40 & 2.91 & 4.50 & 5.10 & 6.18 & 3.70 & 4.80 & 7.47 & 5.84 & 1.20 & 2.62 & 3.00 & 2.10 \\
\hline $\mathrm{Tb}$ & 0.61 & 0.70 & 0.50 & 0.60 & 0.70 & 0.68 & 0.40 & 0.60 & 0.70 & 0.72 & 0.19 & 0.34 & 0.50 & 0.30 \\
\hline Dy & 2.43 & 2.80 & 2.66 & 2.20 & 2.80 & 2.60 & 1.90 & 2.10 & 2.39 & 2.92 & 0.95 & 1.46 & 2.30 & 1.80 \\
\hline Ho & 0.30 & 0.40 & 0.41 & 0.30 & 0.40 & 0.38 & 0.30 & 0.30 & 0.30 & 0.43 & 0.15 & 0.18 & 0.30 & 0.30 \\
\hline $\mathrm{Er}$ & 0.60 & 0.80 & 0.91 & 0.60 & 0.80 & 0.82 & 0.60 & 0.60 & 0.69 & 0.95 & 0.32 & 0.40 & 0.60 & 0.60 \\
\hline $\mathrm{Tm}$ & 0.07 & 0.11 & 0.11 & 0.07 & 0.10 & 0.10 & 0.09 & 0.07 & 0.06 & 0.11 & 0.04 & 0.40 & 0.08 & 0.08 \\
\hline $\mathrm{Yb}$ & 0.39 & 0.60 & 0.64 & 0.40 & 0.50 & 0.62 & 0.60 & 0.30 & 0.46 & 0.66 & 0.27 & 0.26 & 0.50 & 0.50 \\
\hline $\mathrm{Lu}$ & 0.05 & 0.09 & 0.08 & 0.06 & 0.07 & 0.08 & 0.09 & 0.05 & 0.05 & 0.07 & 0.04 & 0.03 & 0.06 & 0.07 \\
\hline $\mathrm{Hf}$ & 2.21 & 5.10 & 0.48 & 2.80 & 3.10 & 5.09 & 3.40 & 2.90 & 2.18 & 2.09 & 1.06 & $<0.06$ & 2.10 & 1.50 \\
\hline $\mathrm{Ta}$ & 1.05 & 0.80 & 1.61 & 1.10 & 1.60 & 1.27 & 1.40 & 0.90 & 0.52 & 1.23 & 2.09 & 1.07 & 2.10 & 2.50 \\
\hline $\mathrm{Pb}$ & 39.00 & 34.00 & 34.00 & 36.00 & 33.00 & 36.00 & 34.00 & 37.00 & 53.00 & 34.00 & $\frac{c .00}{21.00}$ & $\frac{1.01}{33.00}$ & 26.00 & 42.00 \\
\hline Th & 32.41 & 57.10 & 21.08 & 14.00 & 22.30 & 66.13 & 17.00 & 24.60 & 38.52 & 36.34 & 2.48 & 14.02 & 4.90 & 3.40 \\
\hline U & 19.28 & 11.60 & 12.44 & 9.90 & 10.70 & 13.69 & 10.30 & 10.60 & 10.11 & 13.20 & 3.67 & 13.15 & 5.70 & 5.80 \\
\hline REE & 174.34 & 348.94 & 92.13 & 135.78 & 163.34 & 336.28 & 169.93 & 162.66 & 300.24 & 202.10 & 27.00 & 77.70 & 65.95 & 44.25 \\
\hline LREE & 164.08 & 336.30 & 83.67 & 126.48 & 152.42 & 324.23 & 161.50 & 153.28 & 287.33 & 189.93 & 23.74 & 72.14 & 58.27 & 37.99 \\
\hline HREE & 10.26 & 12.64 & 8.46 & 9.30 & 10.92 & 12.05 & 8.43 & 9.38 & 12.91 & 12.17 & 3.27 & 5.56 & 7.68 & 6.26 \\
\hline LREE/HREE & 15.99 & 26.61 & 9.89 & 13.60 & 13.96 & 26.90 & 19.16 & 16.34 & 22.27 & 15.61 & 7.27 & 12.98 & 7.59 & 6.07 \\
\hline $\mathrm{La} / \mathrm{Yb}_{\mathrm{N}}$ & 58.29 & 73.41 & 17.92 & 44.79 & 40.95 & 69.91 & 43.55 & 70.04 & 90.16 & 38.33 & 12.66 & 38.24 & 16.70 & 11.45 \\
\hline $\mathrm{La} / \mathrm{Sm}_{\mathrm{N}}$ & 2.59 & 3.19 & 2.70 & 2.65 & 2.73 & 3.23 & 4.43 & 2.65 & 2.93 & 2.53 & $\frac{12.00}{2.60}$ & $\frac{30 . \angle 4}{2.64}$ & $\frac{10.10}{2.36}$ & 2.43 \\
\hline $\mathrm{Dy} / \mathrm{Yb}_{\mathrm{N}}$ & 4.06 & 3.03 & 2.71 & 3.57 & 3.64 & 2.71 & 2.06 & 4.55 & 3.39 & 2.86 & 2.31 & 3.58 & 2.99 & 2.34 \\
\hline $\mathrm{Tb} / \mathrm{Yb}_{\mathrm{N}}$ & 6.94 & 5.13 & 3.45 & 6.60 & 6.16 & 4.82 & 2.93 & 8.80 & 6.72 & 4.78 & 5.69 & 3.12 & 4.40 & 2.64 \\
\hline $\mathrm{Eu} / \mathrm{Eu}^{*}$ & 0.23 & 0.25 & 0.23 & 0.33 & 0.23 & 0.20 & 0.51 & 0.29 & 0.24 & 0.19 & 0.28 & 0.23 & 0.33 & 0.73 \\
\hline
\end{tabular}


Table 3

\begin{tabular}{|c|c|c|c|c|c|c|c|c|c|c|c|c|c|c|c|c|c|c|c|}
\hline $\begin{array}{c}\text { Litholog } \\
\mathrm{y}\end{array}$ & \multicolumn{3}{|c|}{ Phyllite } & \multicolumn{5}{|c|}{ Metatexite } & \multicolumn{4}{|c|}{ Type-1 Diatexite } & $\begin{array}{c}\text { Type-2 } \\
\text { Diatexite }\end{array}$ & $\begin{array}{c}\text { Granite } \\
X\end{array}$ & $\underset{\text { IX }}{\text { Granite }}$ & $\begin{array}{c}\text { Granite } \\
\text { VIII }\end{array}$ & $\begin{array}{c}\text { Granite } \\
\mathrm{V}\end{array}$ & $\begin{array}{c}\text { Granite } \\
\text { III }\end{array}$ & $\begin{array}{c}\text { Granite } \\
\text { II }\end{array}$ \\
\hline Sample & $\mathrm{M} 1_{1}{ }_{1}-$ & $\mathrm{M}_{2}{ }_{2}^{2}-$ & $\mathrm{M} 1_{3}{ }^{2}$ & $\mathrm{M}_{-}{ }_{1}^{20}$ & $\mathrm{M} 2_{1} 25$ & $\mathrm{M}_{-}{ }_{1}{ }_{-}$ & M4_60A & M5 53 & $\mathrm{M} 2_{-} 43_{-}$ & $\mathrm{M} 2_{2}-43$ & $\mathrm{M} 3_{-} 55_{-}$ & $\mathrm{M}_{3} 55_{-}$ & M1_24A_1 & M4 34 & M3_10_1 & M2_35_1 & $\mathrm{M1}_{-}{ }_{1} 2_{-}$ & M5_13_1 & $\mathrm{M4}_{-} 36$ \\
\hline $\mathrm{Sr}$ & 317 & $\begin{array}{c}1471 \\
\end{array}$ & 333 & 167 & 243 & 487 & 113 & 183 & 112 & $\begin{array}{c} \\
115 \\
\end{array}$ & 144 & $\begin{array}{c}131 \\
\end{array}$ & 86 & $\begin{array}{l}1 \\
78\end{array}$ & 99 & 96 & $\begin{array}{l}1 \\
74\end{array}$ & 76 & 133 \\
\hline $\begin{array}{l}\text { Y } \\
\end{array}$ & 854 & 480 & $\begin{array}{l}305 \\
697\end{array}$ & $\frac{101}{1973}$ & $\frac{245}{1915}$ & $\begin{array}{l}837 \\
837\end{array}$ & 1618 & $\begin{array}{l}103 \\
1457\end{array}$ & 847 & 852 & 1569 & $\frac{151}{1634}$ & 2006 & $\begin{array}{l}10 \\
908\end{array}$ & 542 & $\begin{array}{l}90 \\
1026\end{array}$ & $\begin{array}{c}154 \\
1546\end{array}$ & $\begin{array}{c}10 \\
1083 \\
\end{array}$ & $\frac{103}{212}$ \\
\hline Th & $\frac{054}{27}$ & $\begin{array}{l}400 \\
97\end{array}$ & $\begin{array}{l}097 \\
18\end{array}$ & $\frac{1970}{1}$ & $\frac{1915}{1}$ & $\frac{50}{50}$ & $\frac{1010}{1}$ & $\frac{1451}{0}$ & $\frac{041}{15}$ & $\frac{052}{21}$ & $\frac{1509}{1}$ & $\frac{1034}{0}$ & $\frac{2020}{1}$ & 0 & $\frac{342}{5}$ & $\frac{1020}{5}$ & $\begin{array}{l}1940 \\
19\end{array}$ & $\begin{array}{c}1000 \\
5\end{array}$ & $\frac{12}{4}$ \\
\hline$u$ & 8 & 34 & 18 & 223 & 32 & 17 & 91 & 46 & 33 & 47 & 135 & 123 & 185 & 49 & 51 & 62 & 74 & 75 & 81 \\
\hline $\mathrm{La}$ & 386 & 1585 & 897 & 162 & 167 & 405 & 159 & 126 & 496 & 538 & 192 & 169 & 214 & 391 & 330 & 344 & 380 & 340 & 276 \\
\hline $\mathrm{Ce}$ & 1124 & 2019 & 1672 & 547 & 559 & 921 & 503 & 425 & 1848 & 1924 & 654 & 557 & 574 & 1404 & 879 & 1230 & 1289 & $\begin{array}{l}540 \\
1129 \\
\end{array}$ & 561 \\
\hline $\mathrm{Pr}$ & 175 & 174 & 179 & 91 & 97 & 107 & 83 & 74 & 329 & 336 & 114 & 96 & 79 & 241 & 120 & 214 & 215 & 181 & 66 \\
\hline $\mathrm{Nd}$ & 931 & 630 & 747 & 513 & 565 & 455 & 457 & 435 & 1760 & 1808 & 643 & 533 & 348 & 1282 & 514 & 1115 & 1114 & 899 & 259 \\
\hline $\mathrm{Sm}$ & 253 & 94 & 143 & 216 & 245 & 120 & 190 & 195 & 491 & 502 & 321 & 261 & 142 & 432 & 168 & 377 & 414 & 363 & 67 \\
\hline $\mathrm{Eu}$ & 21 & 21 & 19 & 17 & 26 & 29 & 16 & 17 & 10 & 10 & 14 & 14 & 11 & 10 & 17 & 13 & 8 & 11 & 22 \\
\hline $\mathrm{Gd}$ & 252 & 98 & 158 & 301 & 350 & 145 & 255 & 278 & 315 & 321 & 444 & 361 & 194 & 334 & 160 & 318 & 392 & 345 & 59 \\
\hline $\mathrm{Tb}$ & 33 & 16 & 22 & 60 & 67 & 27 & 50 & 52 & 39 & 39 & 82 & 69 & 48 & 45 & 28 & 47 & 66 & 54 & 10 \\
\hline Dy & 169 & 100 & 130 & 386 & 410 & 166 & 316 & 320 & 181 & 184 & 404 & 378 & 341 & 205 & 124 & 226 & 327 & 255 & 46 \\
\hline $\mathrm{Ho}$ & 29 & 18 & 25 & 77 & 78 & 31 & 61 & 60 & 29 & 30 & 55 & 58 & 67 & 31 & 15 & 35 & 49 & 36 & 6 \\
\hline $\mathrm{Er}$ & 67 & 42 & 60 & 199 & 190 & 78 & 155 & 146 & 68 & 68 & 101 & 130 & 192 & 64 & 31 & 75 & 104 & 73 & 12 \\
\hline$\frac{\mathrm{L}}{\mathrm{Tm}}$ & 8 & $\frac{46}{5}$ & 8 & 28 & 25 & 11 & 22 & 19 & $\frac{00}{9}$ & $\frac{0}{9}$ & 11 & 17 & 32 & 8 & 4 & $\frac{10}{9}$ & 13 & 8 & 2 \\
\hline $\mathrm{Yb}$ & 51 & 33 & 46 & $\begin{array}{l}20 \\
183\end{array}$ & 148 & 73 & $\frac{2 L}{145}$ & 120 & 52 & 53 & $\frac{11}{64}$ & 111 & 231 & 41 & 24 & 53 & 70 & $\begin{array}{l}0 \\
46 \\
\end{array}$ & $\begin{array}{ll}10 \\
\end{array}$ \\
\hline$\frac{\text { ro }}{\text { Lu }}$ & $\begin{array}{l}31 \\
7\end{array}$ & $\frac{35}{4}$ & $\frac{40}{7}$ & $\frac{103}{25}$ & $\begin{array}{l}40 \\
19\end{array}$ & $\frac{15}{9}$ & $\begin{array}{l}45 \\
19\end{array}$ & $\frac{120}{16}$ & $\frac{54}{7}$ & $\frac{35}{7}$ & $\frac{04}{8}$ & 14 & $\frac{201}{31}$ & $\frac{41}{5}$ & $\frac{24}{3}$ & $\frac{50}{6}$ & $\frac{10}{8}$ & $\frac{40}{5}$ & 10 \\
\hline $\begin{array}{c}\text { LU } \\
\text { LREE }\end{array}$ & $\frac{1}{2870}$ & $\begin{array}{c}4 \\
4503\end{array}$ & $\frac{1}{3638}$ & $\begin{array}{c}25 \\
1529\end{array}$ & $\frac{19}{1632}$ & $\frac{9}{2008}$ & $\frac{19}{1391}$ & $\begin{array}{l}10 \\
1255\end{array}$ & $\frac{1}{4924}$ & $\frac{1}{5108}$ & $\begin{array}{c}8 \\
1923\end{array}$ & $\begin{array}{l}14 \\
1615\end{array}$ & $\frac{31}{1357}$ & $\begin{array}{c}5 \\
3750\end{array}$ & $\frac{3}{2011}$ & $\begin{array}{c}6 \\
3279\end{array}$ & 8 & $\begin{array}{c}5 \\
2911\end{array}$ & $\frac{1}{1229}$ \\
\hline $\begin{array}{l}\text { L L } \\
\text { HREEE }\end{array}$ & $\begin{array}{r}2810 \\
638\end{array}$ & $\begin{array}{r}4503 \\
338\end{array}$ & $\begin{array}{c}3638 \\
474\end{array}$ & $\frac{1529}{1275}$ & $\frac{1032}{1311}$ & $\begin{array}{r}2008 \\
569\end{array}$ & $\frac{1391}{1039}$ & $\begin{array}{l}1525 \\
1028\end{array}$ & $\begin{array}{l}4924 \\
709\end{array}$ & $\begin{array}{l}50108 \\
720\end{array}$ & $\begin{array}{l}1923 \\
1183\end{array}$ & $\frac{1615}{1153}$ & $\frac{1358}{1147}$ & $\frac{3 / 50}{742}$ & 407 & $\frac{329}{783}$ & $\frac{3433}{1036}$ & $\frac{2911}{833}$ & $\frac{1229}{168}$ \\
\hline REE & 3508 & 4841 & 41112 & 2804 & 2943 & 2577 & 2431 & 2283 & 5633 & 5829 & 3106 & 2768 & 2504 & 4493 & 2418 & 4062 & 4448 & 3744 & 1397 \\
\hline $\begin{array}{c}E u / E u^{*} \\
\end{array}$ & 0.25 & $\begin{array}{l}4041 \\
0.67\end{array}$ & 0.39 & 0.20 & $\begin{array}{l}2.27 \\
0.27\end{array}$ & 0.67 & 0.22 & $\begin{array}{l}0.22 \\
0.25\end{array}$ & $\begin{array}{l}0.07 \\
\end{array}$ & $\begin{array}{l}0.08 \\
\end{array}$ & 0.12 & 0.14 & $\begin{array}{l}2.194 \\
0.19\end{array}$ & $\begin{array}{l}0.08 \\
\end{array}$ & $\begin{array}{l}2.310 \\
0.33\end{array}$ & $\begin{array}{l}0.11 \\
0.15\end{array}$ & $\begin{array}{l}0.06 \\
0.06\end{array}$ & $\begin{array}{l}0.09 \\
\end{array}$ & $\begin{array}{l}1.06 \\
\end{array}$ \\
\hline $\mathrm{La} / \mathrm{Yb}_{\mathrm{N}}$ & $\begin{array}{l}5.1 \\
\end{array}$ & 32.6 & $\begin{array}{l}.05 \\
13.0\end{array}$ & 0.6 & $\begin{array}{l}0.51 \\
0.8\end{array}$ & 3.7 & 0.7 & 0.7 & $\begin{array}{l}6.41 \\
\end{array}$ & $\begin{array}{l}6.00 \\
6.8\end{array}$ & 2.0 & $\begin{array}{l}0.1 .0 \\
1.0\end{array}$ & $\begin{array}{l}0.1 \\
0.6\end{array}$ & $\frac{0.00}{6.5}$ & $\begin{array}{l}.1 \\
\end{array}$ & 4.3 & 3.7 & 5.0 & 19.1 \\
\hline $\mathrm{La} / \mathrm{S} \mathrm{m}_{\mathrm{N}}$ & $\begin{array}{l}.1 .0 \\
\end{array}$ & $\begin{array}{l}x .0 \\
10.6\end{array}$ & $\frac{10.0}{3.9}$ & $\begin{array}{l}0.0 \\
0.5\end{array}$ & $\begin{array}{l}0.0 \\
0.4\end{array}$ & $\begin{array}{l}.1 \\
2.1\end{array}$ & $\begin{array}{l}0.1 \\
0.5\end{array}$ & $\begin{array}{l}.1 \\
0.4\end{array}$ & $\begin{array}{l}0.4 \\
0.6\end{array}$ & $\begin{array}{l}0.0 \\
0.7\end{array}$ & $\begin{array}{l}.0 \\
0.4\end{array}$ & 0.4 & $\begin{array}{l}0.0 \\
0.9\end{array}$ & $\begin{array}{l}0.3 \\
0.6\end{array}$ & $\begin{array}{l}.1 \\
1.2\end{array}$ & $\begin{array}{l}4.0 \\
0.6\end{array}$ & $\begin{array}{l}0.1 \\
0.6\end{array}$ & $\begin{array}{l}.0 .6 \\
\end{array}$ & $\begin{array}{l}2.1 .1 \\
2.6\end{array}$ \\
\hline$\frac{1}{D y} / \mathrm{Vb}_{N}$ & 2.0 & $\frac{10.0}{2.0}$ & $\frac{3.9}{1.8}$ & $\begin{array}{l}.5 \\
1.4\end{array}$ & $\frac{1.4}{1.8}$ & $\begin{array}{l}.1 \\
1.5\end{array}$ & $\begin{array}{l}.5 \\
1.4\end{array}$ & $\begin{array}{l}.4 \\
1.7\end{array}$ & $\begin{array}{l}.6 \\
.3\end{array}$ & $\frac{.1}{2.2}$ & $\begin{array}{l}4.4 \\
4.1\end{array}$ & $\frac{1.4}{2.2}$ & $\begin{array}{l}.5 \\
1.0\end{array}$ & $\begin{array}{l}.6 \\
.3\end{array}$ & $\begin{array}{l}1.2 \\
3.3\end{array}$ & $\begin{array}{l}.0 \\
2.8\end{array}$ & $\begin{array}{l}3.6 \\
3.0\end{array}$ & $\begin{array}{l}.6 \\
.6\end{array}$ & $\begin{array}{l}3.0 \\
3.1\end{array}$ \\
\hline
\end{tabular}

Table 4

\begin{tabular}{|c|c|c|c|c|c|c|c|c|c|c|c|c|c|c|c|c|c|c|c|c|c|c|c|}
\hline $\begin{array}{l}\text { Lith } \\
\text { olog }\end{array}$ & \multicolumn{11}{|c|}{ Metatexite } & \multicolumn{2}{|c|}{ Type-1 Diatexite } & $\begin{array}{c}\text { Type-2 } \\
\text { Diatexit }\end{array}$ & \multicolumn{7}{|c|}{ Granite X } & \multirow{2}{*}{$\begin{array}{c}\text { Grani } \\
\text { te IX } \\
\mathrm{M} 6 \mathrm{~T} \\
-45_{-} \\
\overline{1}-\overline{1} \\
\end{array}$} & \multirow{2}{*}{$\begin{array}{c}\begin{array}{c}\text { Granit } \\
\mathrm{eV}\end{array} \\
\mathrm{M} 6 \mathrm{~T} \\
12{ }_{-1 \mathrm{C}} \\
-1\end{array}$} \\
\hline $\begin{array}{c}\text { Sam } \\
\text { ple }\end{array}$ & $\begin{array}{l}\text { M1T } \\
20 \_11 \\
c-1 \\
\text { c-1 }\end{array}$ & $\begin{array}{c}\text { M1T } \\
20 \_25 \\
c-1 \\
\end{array}$ & $\begin{array}{l}\text { M1T } \\
2046 \\
c-1 \\
c-1\end{array}$ & $\begin{array}{l}\text { M1T } \\
20 \_57 \\
c-1 \\
c-1\end{array}$ & $\begin{array}{l}\text { M1T } \\
20 \_78 \\
c-1 \\
c-1\end{array}$ & $\begin{array}{c}\text { M6T } \\
25-1 \mathrm{C} \\
-1 \\
\end{array}$ & $\begin{array}{c}\text { M6T } \\
252 \mathrm{C} \\
-1 \\
\end{array}$ & $\begin{array}{c}\text { M6T } \\
25-3 \mathrm{c} \\
-1 \\
\end{array}$ & $\begin{array}{l}\text { M6T } \\
25-4 \mathrm{C} \\
-1 \\
\end{array}$ & $\begin{array}{c}\text { M6T_ } \\
25-5 \mathrm{c} \\
-1 \\
\end{array}$ & $\begin{array}{c}\text { M6T } \\
25-7 \mathrm{C} \\
-1 \\
\end{array}$ & $\begin{array}{c}\text { M6T } \\
55 \_10 \\
c-1 \\
c-1\end{array}$ & 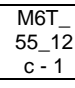 & $\begin{array}{c}\text { M1T_2 } \\
4 A_{-17 \mathrm{c}} \\
-1\end{array}$ & $\begin{array}{l}\text { M6T_34 } \\
-10 \mathrm{c}-1 \\
\end{array}$ & $\begin{array}{l}\text { M6T_34 } \\
-15 c-1 \\
\end{array}$ & $\begin{array}{l}\text { M6T_34 } \\
23 c-1 \\
\end{array}$ & $\begin{array}{l}\text { M6T_34 } \\
224 c-1 \\
\end{array}$ & $\begin{array}{l}\text { M6T_34 } \\
-26 \mathrm{c}-1 \\
\end{array}$ & \begin{tabular}{|l|} 
M6T_34 \\
$-27 \mathrm{c}-1$ \\
\end{tabular} & $\begin{array}{c}\text { M6T_3 } \\
4 \_3 c- \\
1\end{array}$ & & \\
\hline $\mathrm{Hf}$ & 10140 & 11080 & 8180 & 12530 & 10000 & $\begin{array}{c}1430 \\
0\end{array}$ & $\begin{array}{c}1329 \\
0\end{array}$ & $\begin{array}{c}1326 \\
0\end{array}$ & $\begin{array}{c}1330 \\
0\end{array}$ & $\begin{array}{c}1441 \\
0\end{array}$ & $\begin{array}{c}1436 \\
0\end{array}$ & 12750 & 11060 & 11810 & 12850 & 11660 & 11990 & 12070 & 12430 & 12670 & 12650 & $\begin{array}{c}1028 \\
0\end{array}$ & $\begin{array}{c}1195 \\
0\end{array}$ \\
\hline$U$ & 1152 & 341 & 97 & 2171 & 851 & 1310 & 1137 & 1261 & 1378 & 1213 & 1239 & 475 & 1514 & 321 & 734 & 1258 & 1182 & 1603 & 1480 & 1000 & 190 & 898 & 2770 \\
\hline Th & 419 & 288 & 57 & 520 & 253 & 4 & 3 & 6 & 4 & 4 & 5 & 28 & 117 & 37 & 84 & 314 & 284 & 398 & 7400 & 980 & 68 & 214 & $\begin{array}{c}1630 \\
0\end{array}$ \\
\hline$\underset{\mathrm{Th} / \mathrm{f}}{\mathrm{u}}$ & 0.36 & 0.85 & 0.58 & 0.24 & 0.30 & 0.003 & 0.003 & 0.005 & 0.003 & 0.003 & 0.004 & 0.06 & 0.08 & 0.12 & 0.11 & 0.25 & 0.24 & 0.25 & 5.00 & 0.98 & 0.36 & 0.24 & 5.88 \\
\hline $\mathrm{Y}$ & & & 677 & & 120 & & & & & & 2074 & & & 610 & 469 & 855 & 797 & 1199 & 985 & 592 & 799 & & - \\
\hline $\mathrm{La}$ & 56 & 0.2 & $<\mathrm{LOD}$ & 14 & 3 & $<\mathrm{LOD}$ & $<L O D$ & $<\mathrm{LOD}$ & $\angle L O D$ & $<L O D$ & 1 & 0.1 & 11 & 0.2 & 0.1 & 2 & 4 & 22 & 731 & 64 & $<L O D$ & 2 & - \\
\hline $\mathrm{Ce}$ & 95 & 23 & 22 & 70 & 29 & 0.1 & 0.1 & 0.1 & 0.1 & 0.1 & 5 & 1 & 54 & 15 & 2 & 17 & 38 & 260 & & 64 & 5 & 17 & \\
\hline $\mathrm{Pr}$ & 8 & 0.2 & 0.1 & 12 & 3 & $<\mathrm{LOD}$ & $<\mathrm{LOD}$ & $\begin{array}{l}0.02 \\
\end{array}$ & $\angle L O D$ & $<\mathrm{LOD}$ & 1 & 0.1 & 11 & 0.3 & 0.3 & 4 & 9 & 33 & 377 & 1 & 0.1 & 4 & - \\
\hline $\mathrm{Nd}$ & 34 & 3 & 2 & 79 & 21 & 0.2 & 0.2 & 0.2 & 0.1 & 0.2 & 6 & 1 & 68 & 2 & 3 & 31 & 10 & 209 & 1920 & 950 & 1 & 27 & 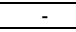 \\
\hline $\mathrm{Sm}$ & 18 & 6 & 3 & 57 & 18 & 1 & 1 & 1 & 1 & 1 & 5 & 2 & 47 & 2 & 6 & 26 & 50 & 90 & 1170 & 153 & 2 & 25 & 3440 \\
\hline$E u$ & 4 & 1 & 1 & 15 & 4 & 0.2 & 0.2 & 0.2 & 0.2 & 0.2 & 2 & 0.2 & 9 & 0.5 & 0.1 & 1 & 2 & 5 & 7 & 2 & 0.1 & 1 & 18 \\
\hline
\end{tabular}




\begin{tabular}{|c|c|c|c|c|c|c|c|c|c|c|c|c|c|c|c|c|c|c|c|c|c|c|c|}
\hline $\mathrm{Gd}$ & 57 & 30 & 15 & 131 & 54 & 12 & 10 & 12 & 12 & 10 & 24 & 14 & 144 & 12 & 23 & 49 & 70 & 106 & 450 & 89 & 13 & 75 & 1380 \\
\hline $\mathrm{Tb}$ & 18 & 10 & 5 & 33 & 16 & 7 & 6 & 8 & 8 & 7 & 11 & 7 & 48 & 4 & 6 & 12 & 14 & 20 & 40 & 13 & 5 & 19 & 115 \\
\hline Dy & 201 & 128 & 58 & 327 & 182 & 139 & 111 & 143 & 143 & 127 & 177 & 98 & 489 & 54 & 58 & 106 & 111 & 158 & 196 & 97 & 76 & 168 & 457 \\
\hline Ho & 69 & 48 & 21 & 94 & 62 & 64 & 52 & 65 & 66 & 59 & 73 & 38 & 120 & 20 & 15 & 28 & 26 & 39 & 38 & 24 & 29 & 45 & 71 \\
\hline $\mathrm{Er}$ & 309 & 230 & 105 & 391 & 288 & 388 & 320 & 394 & 407 & 354 & 419 & 188 & 369 & 101 & 55 & 104 & 91 & 136 & 124 & 89 & 131 & 180 & 200 \\
\hline $\mathrm{Tm}$ & 63 & 49 & 23 & 77 & 62 & 112 & 94 & 112 & 118 & 103 & 115 & 44 & 55 & 23 & 10 & 19 & 16 & 24 & 21 & 17 & 26 & 35 & 31 \\
\hline $\mathrm{Yb}$ & 534 & 439 & 215 & 647 & 552 & 1305 & 1090 & 1284 & 1368 & 1193 & 1307 & 434 & 381 & 225 & 80 & 146 & 118 & 178 & 157 & 132 & 214 & 296 & 231 \\
\hline $\begin{array}{ll}\mathrm{Lu} \\
\end{array}$ & 104 & 92 & 48 & 122 & 116 & 297 & 248 & 290 & 309 & 269 & 295 & 91 & 64 & 48 & 14 & 25 & 20 & 30 & 27 & 23 & 39 & 58 & 38 \\
\hline LRE & 212 & 32 & 27 & 232 & 73 & 1 & 1 & 1 & 1 & 1 & 19 & 4 & 190 & 19 & 11 & 80 & 170 & 614 & 4198 & 1346 & 8 & 75 & 3440 \\
\hline HR & 1357 & 1026 & 490 & 1837 & 1334 & 2324 & 1930 & 2308 & 2430 & 2122 & 2423 & 915 & 1679 & 488 & 261 & 490 & 468 & 696 & 1058 & 486 & 533 & 877 & 2540 \\
\hline $\begin{array}{l}\text { REE } \\
\end{array}$ & 1569 & 1059 & 517 & 2069 & 1407 & 2325 & 1931 & 2309 & 2432 & 2124 & 2442 & 919 & 1869 & 507 & 272 & 570 & 638 & 1310 & 5256 & 1832 & 542 & 952 & 5980 \\
\hline $\begin{array}{l}\mathrm{Yb} / \\
\mathrm{Gd} d_{N}\end{array}$ & 11.64 & 18.19 & 17.93 & 6.11 & 12.73 & $\begin{array}{c}138.1 \\
4\end{array}$ & $\begin{array}{c}140.3 \\
8\end{array}$ & $\begin{array}{c}127.7 \\
1\end{array}$ & $\begin{array}{c}144.8 \\
1\end{array}$ & $\begin{array}{c}141.1 \\
5\end{array}$ & 67.50 & 38.07 & 3.27 & 23.07 & 4.25 & 3.65 & 2.08 & 2.08 & 0.43 & 1.83 & 19.91 & 4.89 & 0.21 \\
\hline $\begin{array}{l}\mathrm{Ce} / \\
\mathrm{YbN}\end{array}$ & 0.05 & 0.01 & 0.03 & 0.03 & 0.01 & $\begin{array}{c}0.000 \\
03\end{array}$ & $\begin{array}{c}0.000 \\
02\end{array}$ & $\begin{array}{c}0.000 \\
02\end{array}$ & $\begin{array}{c}0.000 \\
01\end{array}$ & $\begin{array}{c}0.000 \\
01\end{array}$ & 0.001 & 0.001 & 0.04 & 0.02 & 0.01 & 0.03 & 0.08 & 0.4 & - & 0.1 & 0.01 & 0.01 & - \\
\hline $\begin{array}{l}\mathrm{Eu/} / \\
\mathrm{Eu}^{*}\end{array}$ & 0.34 & 0.30 & 0.51 & 0.52 & 0.43 & 0.17 & 0.17 & 0.16 & 0.17 & 0.17 & 0.44 & 0.14 & 0.33 & 0.26 & 0.03 & 0.09 & 0.12 & 0.16 & 0.03 & 0.04 & 0.04 & 0.07 & 0.02 \\
\hline $\begin{array}{l}\mathrm{Ce} / \\
\mathrm{Ce}^{*}\end{array}$ & 1.09 & 26.09 & - & 1.30 & 2.49 & - & - & - & - & - & 1.15 & 3.77 & 1.22 & 14.55 & 2.43 & 1.39 & 1.52 & 2.34 & - & 0.18 & - & 1.43 & - \\
\hline
\end{tabular}

Table 5

\begin{tabular}{|c|c|c|c|c|c|c|c|c|c|c|c|c|c|c|c|}
\hline \multirow{2}{*}{$\begin{array}{l}\text { Lithology } \\
\text { Sample }\end{array}$} & \multirow{2}{*}{$\begin{array}{c}\text { Phyllite N } \\
\text { JTJ-2 }\end{array}$} & \multirow{2}{*}{$\begin{array}{c}\text { Phyllite S } \\
\text { JTJ-19 }\end{array}$} & \multicolumn{5}{|c|}{ Metatexite } & \multicolumn{2}{|c|}{ Type-1 Diatexite } & \multirow{2}{*}{$\begin{array}{c}\text { Type-2 Diatexite } \\
\text { JTJ-24A }\end{array}$} & \multirow{2}{*}{$\begin{array}{c}\text { Granite X } \\
\text { JTJ-34 }\end{array}$} & \multirow{2}{*}{$\begin{array}{c}\text { Granite IX } \\
\text { JTJ-45 }\end{array}$} & \multirow{2}{*}{$\begin{array}{c}\text { Granite VIII } \\
\text { JTJ-35 }\end{array}$} & \multirow{2}{*}{$\begin{array}{c}\text { Granite V } \\
\text { JTJ-12 }\end{array}$} & \multirow{2}{*}{$\frac{\text { Granite II }}{\text { JTJ-36 }}$} \\
\hline & & & JTJ-20 & JTJ-25 & JTJ-48B & JTJ-53 & JTJ-60A & JTJ-43 & JTJ-55 & & & & & & \\
\hline${ }^{87} \mathrm{Sr} /{ }^{86} \mathrm{Sr}$ & 0.7250 & 0.7402 & 0.7245 & 0.7321 & 0.7318 & 0.7403 & 0.7489 & 0.7364 & 0.7340 & 0.7447 & 0.7648 & 0.7893 & 0.7636 & 0.7774 & 0.7578 \\
\hline $\pm 2 \sigma$ & 0.000013 & 0.000016 & 0.000019 & 0.000016 & 0.000013 & 0.000017 & 0.000034 & 0.000018 & 0.000065 & 0.000020 & 0.000015 & 0.000024 & 0.000025 & 0.000013 & 0.000021 \\
\hline${ }^{87} \mathrm{Sr}^{86} \mathrm{Sr}_{320}$ & 0.7153 & 0.7089 & 0.7097 & 0.7124 & 0.7039 & 0.7099 & 0.7053 & 0.7072 & 0.7204 & 0.7162 & 0.7055 & 0.7062 & 0.7126 & 0.7022 & 0.7063 \\
\hline${ }^{143} \mathrm{Nd} /{ }^{144} \mathrm{Nd}$ & 0.5119 & 0.5126 & 0.5122 & 0.5121 & 0.5120 & 0.5121 & 0.5121 & 0.5120 & 0.5123 & 0.5122 & 0.5120 & 0.5121 & 0.5120 & 0.5120 & 0.5123 \\
\hline $\pm 2 \sigma$ & 0.000011 & 0.000006 & 0.000009 & 0.000010 & 0.000007 & 0.000009 & 0.000009 & 0.000009 & 0.000011 & 0.000007 & 0.000009 & 0.000008 & 0.000009 & 0.000012 & 0.000012 \\
\hline$\varepsilon N d$ & -13.42 & 0.15 & -8.30 & -10.91 & -12.28 & -10.57 & -10.99 & -12.77 & -7.16 & -8.28 & -12.66 & -11.06 & -12.18 & -11.51 & -7.49 \\
\hline$\varepsilon \mathrm{Nd}_{320}$ & -10.07 & 3.28 & -5.21 & -7.65 & -8.86 & -7.30 & -8.08 & -8.32 & -5.05 & -6.21 & -8.89 & -7.99 & -8.36 & -8.64 & -6.03 \\
\hline $\mathrm{Nd} \mathrm{T}_{\mathrm{DM} 2}(\mathrm{Ma})^{\mathrm{a}}$ & 1826 & 779 & 1445 & 1637 & 1731 & 1609 & 1670 & 1524 & 1690 & 1433 & 1714 & 1734 & 1693 & 1664 & 1510 \\
\hline${ }^{176} \mathrm{Hf} /{ }^{177} \mathrm{Hf}$ & 0.2823 & 0.2824 & 0.2825 & 0.2824 & 0.2824 & 0.2825 & 0.2824 & 0.2824 & 0.2825 & 0.2824 & 0.2823 & 0.2824 & 0.2824 & 0.2824 & 0.2825 \\
\hline $\pm 2 \sigma$ & 0.000005 & 0.000005 & 0.000004 & 0.000009 & 0.000005 & 0.000004 & 0.000005 & 0.000005 & 0.000005 & 0.000007 & 0.000006 & 0.000006 & 0.000005 & 0.000004 & 0.000005 \\
\hline$\varepsilon \mathrm{Hf}$ & -18.14 & -11.40 & -8.98 & -11.41 & -12.09 & -9.44 & -12.82 & -14.92 & -9.25 & -12.02 & -15.16 & -13.99 & -14.21 & -14.06 & -10.16 \\
\hline$\varepsilon \mathrm{Hf}_{320}$ & -13.68 & -7.16 & -4.45 & -7.99 & -8.47 & -6.45 & -8.16 & -8.16 & -3.42 & -9.25 & -8.43 & -7.78 & -7.71 & -7.70 & -3.99 \\
\hline
\end{tabular}




\begin{tabular}{|c|c|c|c|c|c|c|c|c|c|c|c|c|c|c|c|}
\hline $\mathrm{Hf}_{\mathrm{DM} 2}(\mathrm{Ma})^{\mathrm{b}}$ & 2160 & 1747 & 1574 & 1800 & 1830 & 1701 & 1810 & 1880 & 1810 & 1508 & 1781 & 1828 & 1781 & 1786 & 1544 \\
\hline${ }^{208} \mathrm{~Pb} /{ }^{204} \mathrm{~Pb}$ & 38.7956 & 38.6236 & 38.6820 & 38.8925 & 39.2638 & 38.6856 & 38.4898 & 39.9730 & 38.4068 & 38.2375 & 42.1802 & 38.6802 & 39.2789 & 38.9877 & 38.3497 \\
\hline $\pm 2 \sigma$ & 0.0021 & 0.0023 & 0.0023 & 0.0021 & 0.0018 & 0.0013 & 0.0022 & 0.0022 & 0.0026 & 0.0024 & 0.0022 & 0.0021 & 0.0017 & 0.0014 & 0.0023 \\
\hline${ }^{206} \mathrm{~Pb} /{ }^{204} \mathrm{~Pb}$ & 18.3550 & 19.0401 & 18.7160 & 18.6505 & 18.6196 & 19.0338 & 18.5718 & 18.5110 & 18.4268 & 18.2206 & 19.0352 & 18.6156 & 18.6437 & 18.6888 & 18.6227 \\
\hline $\pm 2 \sigma$ & 0.0009 & 0.0010 & 0.0011 & 0.0010 & 0.0009 & 0.0005 & 0.0011 & 0.0010 & 0.0011 & 0.0009 & 0.0009 & 0.0010 & 0.0007 & 0.0006 & 0.0009 \\
\hline${ }^{207} \mathrm{~Pb} /{ }^{204} \mathrm{~Pb}$ & 15.6924 & 15.6746 & 15.6434 & 15.6434 & 15.6485 & 15.6848 & 15.6502 & 15.6483 & 15.6407 & 15.6246 & 15.6830 & 15.6541 & 15.6583 & 15.6631 & 15.6618 \\
\hline $\pm 2 \sigma$ & 0.0008 & 0.0008 & 0.0009 & 0.0008 & 0.0007 & 0.0005 & 0.0009 & 0.0008 & 0.0010 & 0.0008 & 0.0008 & 0.0008 & 0.0007 & 0.0005 & 0.0008 \\
\hline${ }^{208} \mathrm{~Pb} /{ }^{206} \mathrm{~Pb}$ & 2.1136 & 2.0285 & 2.0668 & 2.0853 & 2.1087 & 2.0325 & 2.0724 & 2.1594 & 2.0843 & 2.0986 & 2.2159 & 2.0778 & 2.1068 & 2.0862 & 2.0593 \\
\hline $\pm 2 \sigma$ & 0.000029 & 0.000033 & 0.000037 & 0.000046 & 0.000034 & 0.000027 & 0.000037 & 0.000041 & 0.000032 & 0.000037 & 0.000030 & 0.000046 & 0.000039 & 0.000045 & 0.000086 \\
\hline${ }^{207} \mathrm{~Pb} /{ }^{206} \mathrm{~Pb}$ & 0.8549 & 0.8232 & 0.8358 & 0.8388 & 0.8404 & 0.8241 & 0.8427 & 0.8453 & 0.8488 & 0.8575 & 0.8239 & 0.8409 & 0.8399 & 0.8381 & 0.8410 \\
\hline $\pm 2 \sigma$ & 0.000011 & 0.000011 & 0.000013 & 0.000016 & 0.000010 & 0.000008 & 0.000011 & 0.000014 & 0.000010 & 0.000010 & 0.000010 & 0.000015 & 0.000010 & 0.000015 & 0.000024 \\
\hline${ }^{206} \mathrm{~Pb} /{ }^{204} \mathrm{~Pb}_{320}$ & 17.8770 & 17.9549 & 17.9149 & 17.9774 & 17.7057 & 12.7938 & 18.0033 & 17.7218 & 17.9120 & 17.2398 & 18.1733 & 17.4132 & 17.5719 & 17.6702 & 17.9340 \\
\hline${ }^{207} \mathrm{~Pb}^{204} \mathrm{~Pb}_{320}$ & 15.6671 & 15.6173 & 15.6011 & 15.6079 & 15.6002 & 15.3554 & 15.6201 & 15.6067 & 15.6135 & 15.5728 & 15.6375 & 15.5907 & 15.6017 & 15.6093 & 15.6254 \\
\hline${ }^{208} \mathrm{~Pb} /{ }^{204} \mathrm{~Pb}_{320}$ & 38.0388 & 37.6798 & 38.1323 & 38.2769 & 38.6531 & 38.1212 & 38.2232 & 36.6712 & 38.2117 & 38.2151 & 39.3876 & 38.1326 & 37.5695 & 38.2999 & 38.1579 \\
\hline
\end{tabular}

${ }^{\mathrm{a}} \mathrm{T}_{\mathrm{DM} 2}=1 / \lambda \times \ln \left({ }^{143} \mathrm{Nd} /{ }^{144} \mathrm{Nd}-\left(\mathrm{e}^{\lambda \mathrm{t}}-1\right) \times\left({ }^{147} \mathrm{Sm} /{ }^{144} \mathrm{Nd}-{ }^{147} \mathrm{Sm} /{ }^{144} \mathrm{Nd} \mathrm{CC}_{\mathrm{C}}-{ }^{143} \mathrm{Nd} /{ }^{144} \mathrm{Nd} d_{\mathrm{DM}} /\left({ }^{147} \mathrm{Sm} /{ }^{144} \mathrm{Nd}_{\mathrm{CC}}{ }^{147} \mathrm{Sm} /{ }^{144} \mathrm{Nd} \mathrm{DM}\right)+1\right)\right.$

${ }^{\mathrm{b}} \mathrm{T}_{\mathrm{DM} 2}=1 / \lambda \times \ln \left({ }^{176} \mathrm{Hf} /{ }^{177} \mathrm{Hf}-\left(e^{\lambda \mathrm{t}}-1\right) \times\left({ }^{176} \mathrm{Lu} /{ }^{177} \mathrm{Hf}-{ }^{176} \mathrm{Lu} /{ }^{177} \mathrm{Hf} \mathrm{CC}_{\mathrm{CC}}-{ }^{176} \mathrm{Hf} /{ }^{177} \mathrm{Hf} \mathrm{fM}_{\mathrm{DM}} /\left({ }^{176} \mathrm{Lu} /{ }^{177} \mathrm{Hf}_{\mathrm{CC}}{ }^{176} \mathrm{Lu} /{ }^{177} \mathrm{Hf} \mathrm{DM}\right)+1\right)\right.$

$\lambda R b$ - Steiger and Jäger (1977)

$\lambda \mathrm{Sm}$ - Lugmair and Marti (1978)

$\lambda L u$ - Söderlund et al. (2004)

$\lambda U$ and $\lambda T h$ - Steiger and Jäger (1977)

${ }^{147} \mathrm{Sm} /{ }^{144} \mathrm{Nd} d_{\text {CHUR }}$ and ${ }^{143} \mathrm{Nd} /{ }^{144} \mathrm{Nd} d_{\text {CHUR }}$ - Jacobsen and Wasserburg (1980)

${ }^{147} \mathrm{Sm} / 144 \mathrm{Nd} d_{\mathrm{DM}}, 143 \mathrm{Nd} /{ }^{144} \mathrm{Nd} d_{\mathrm{DM}}$, and ${ }^{147} \mathrm{Sm} /{ }^{144} \mathrm{Nd} d_{\mathrm{CC}}$ - Liew and Hofmann (1988)

${ }^{176} \mathrm{Lu} /{ }^{177} \mathrm{Hf} \mathrm{CHUR}_{\mathrm{CH}}$ and ${ }^{176} \mathrm{Hf} /{ }^{177} \mathrm{Hf} \mathrm{CHUR}_{\mathrm{CH}}$ - Blichert-Toft and Albarède (1997)

${ }^{176} \mathrm{Lu} /{ }^{177} \mathrm{Hf} f_{D M}$ and ${ }^{176} \mathrm{Hf} /{ }^{177} \mathrm{Hf}_{\mathrm{DM}}$ - Vervoort and Blichert-Toft (1999)

${ }^{176} \mathrm{Lu}^{177} \mathrm{Hf}_{\mathrm{CC}}$ - Griffin et al. (2002) 
External Fold and Thrust belt

Gondwana zones with strong Cadomian imprint

Gondwana zones with Early ordovician magmatism

Allochthonous terranes (HP rocks and ophiolites) a - parautochton

Variscan Miogeocline Fold Variscan Miogeocline Fold
and Thrust Metamorphic belt and Thrust Metamorphic belt Variscan foreland Thrust belt

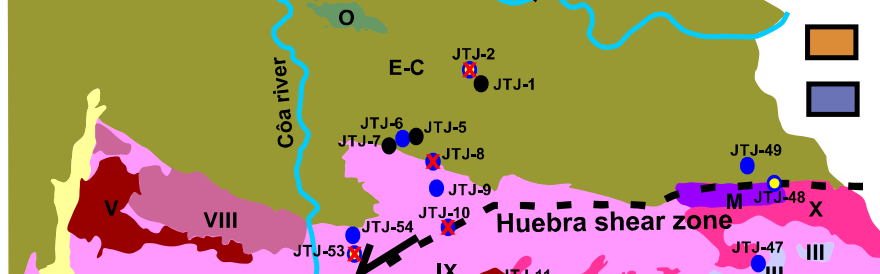

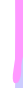

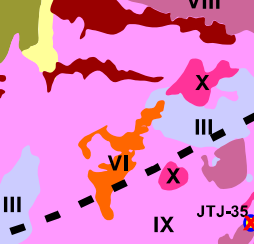

Huebra shear zone
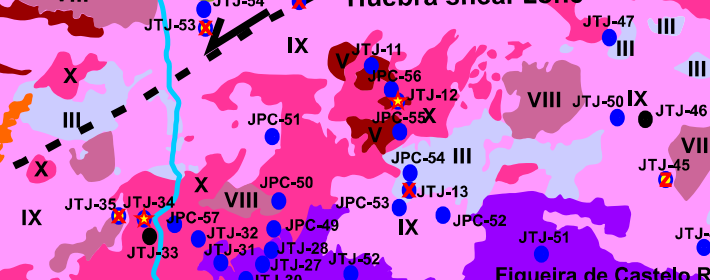

งTJ-40
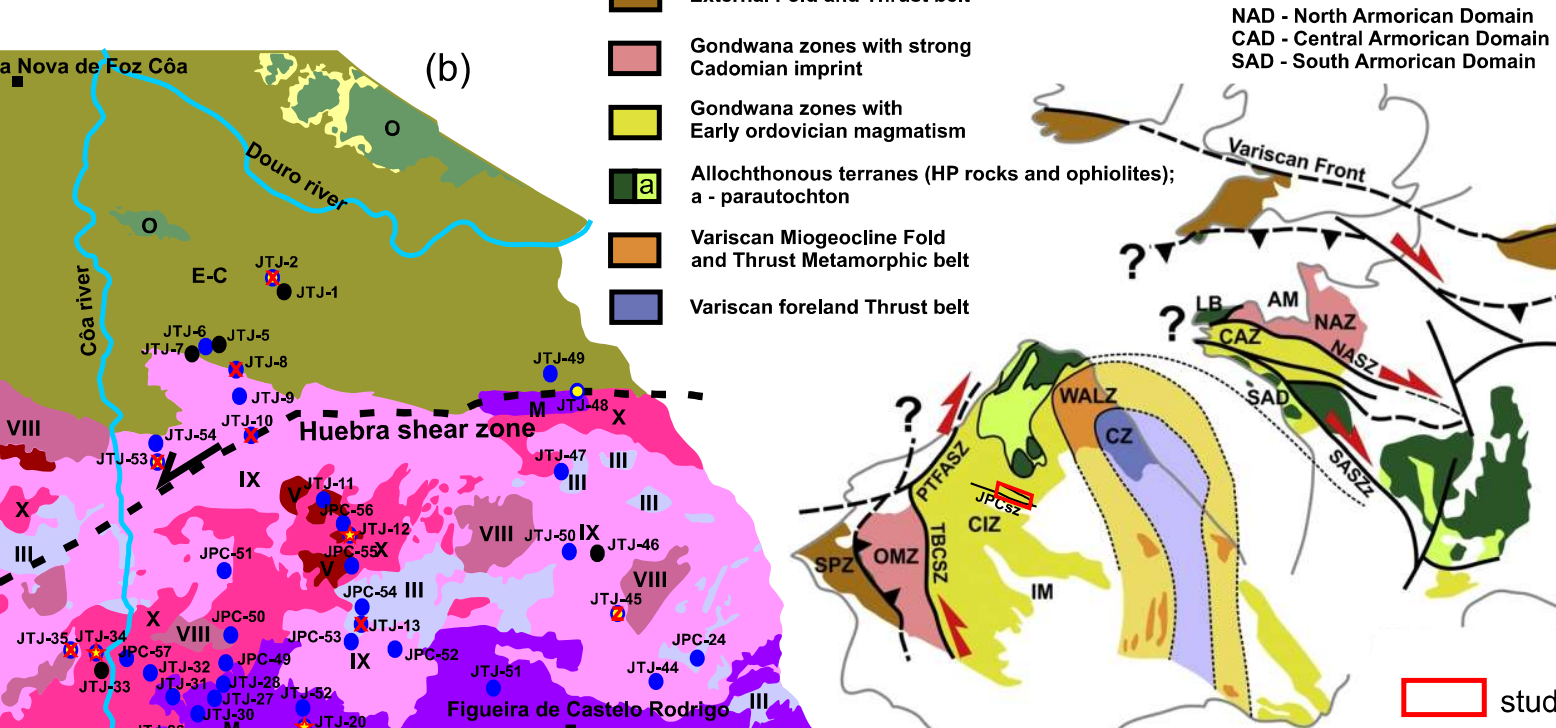
CAD - Central Armorican Domain SAD - South Armorican Domain

(a)
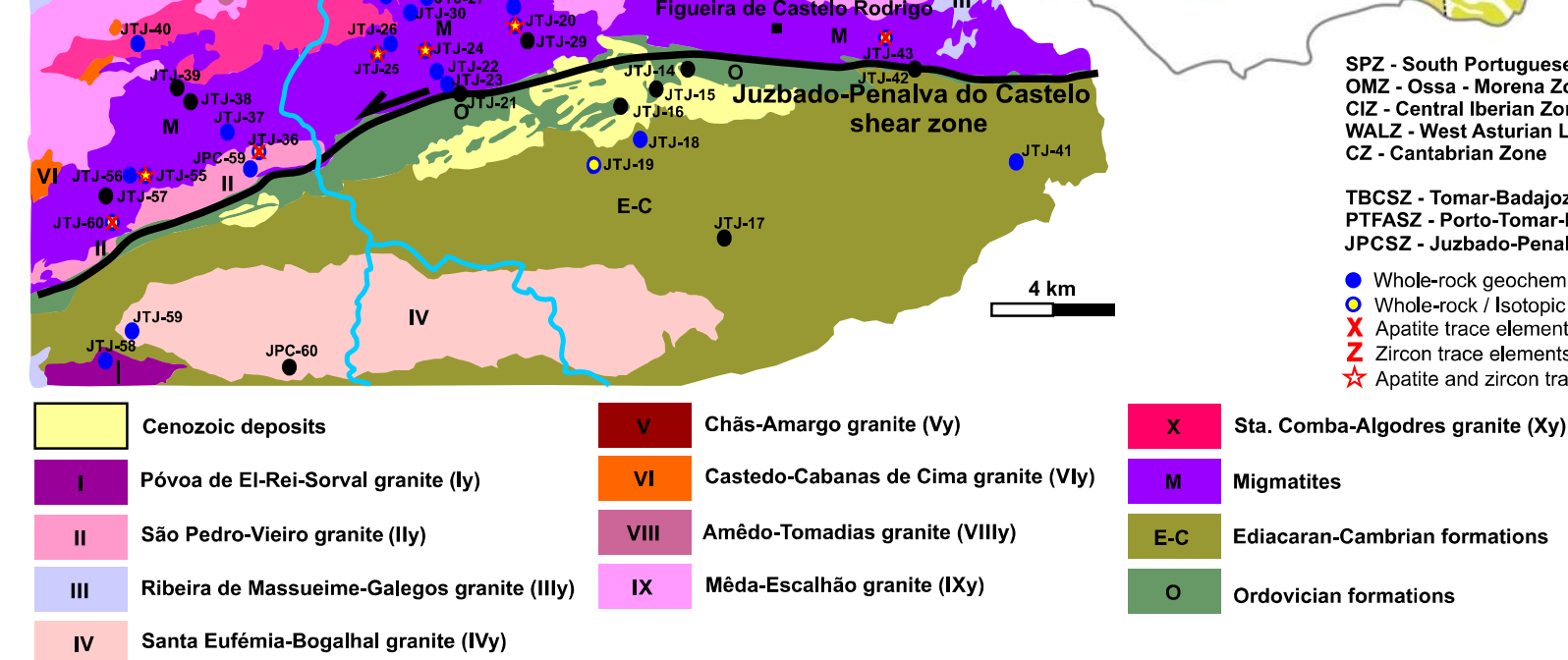

SPZ - South Portuguese Zone

OMZ - Ossa - Morena Zone

CIZ - Central lberian Zone

WALZ - West Asturian Leonese Zone

CZ - Cantabrian Zone

TBCSZ - Tomar-Badajoz-Córdova Shear Zone

PTFASZ - Porto-Tomar-Ferreira do Alentejo Shear Zone

JPCSZ - Juzbado-Penalva do Castelo Shear Zone

- Whole-rock geochemistry samples

O Whole-rock / Isotopic geochemistry samples

X Apatite trace elements samples

Z Zircon trace elements samples

Z Zircon trace elements samples 


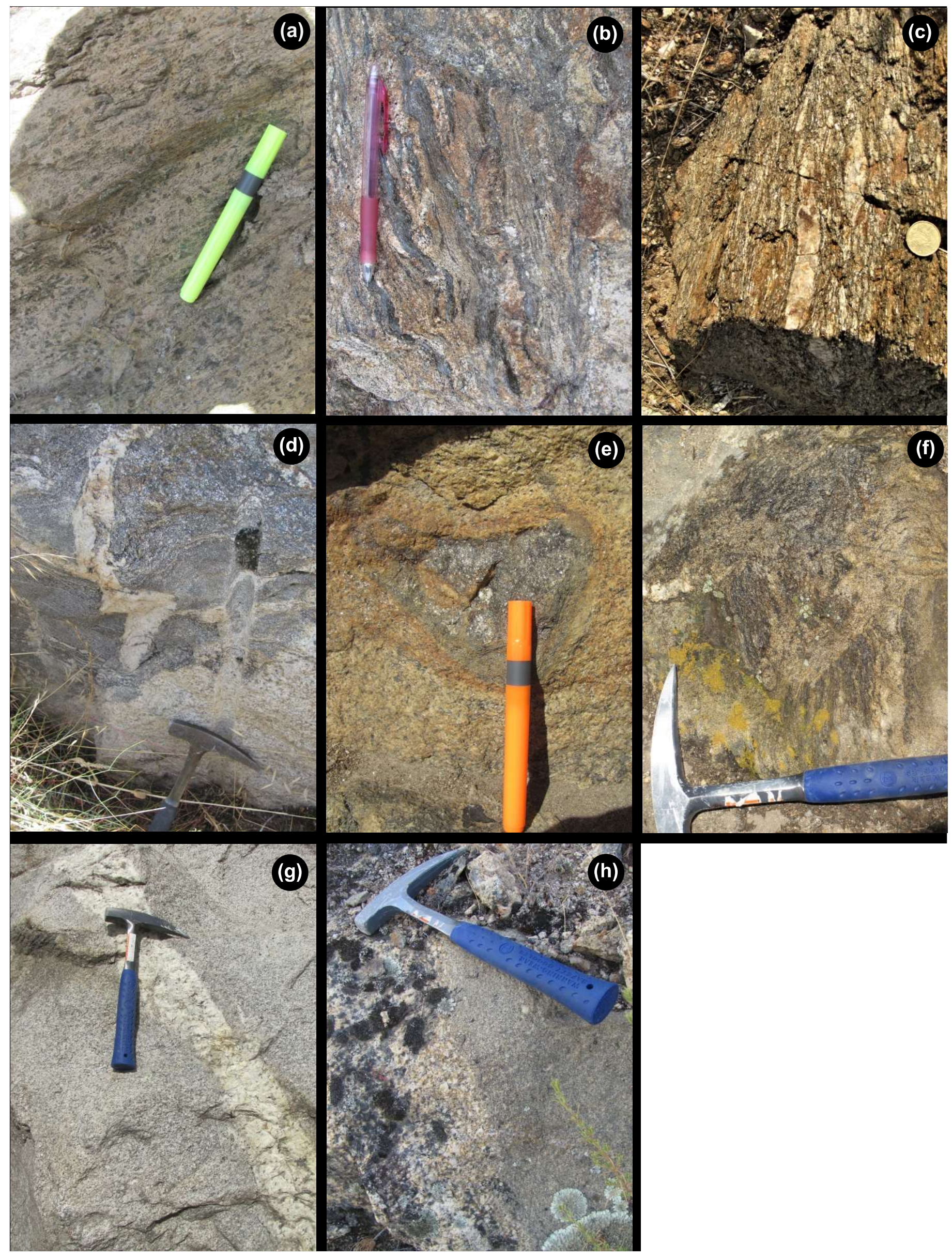



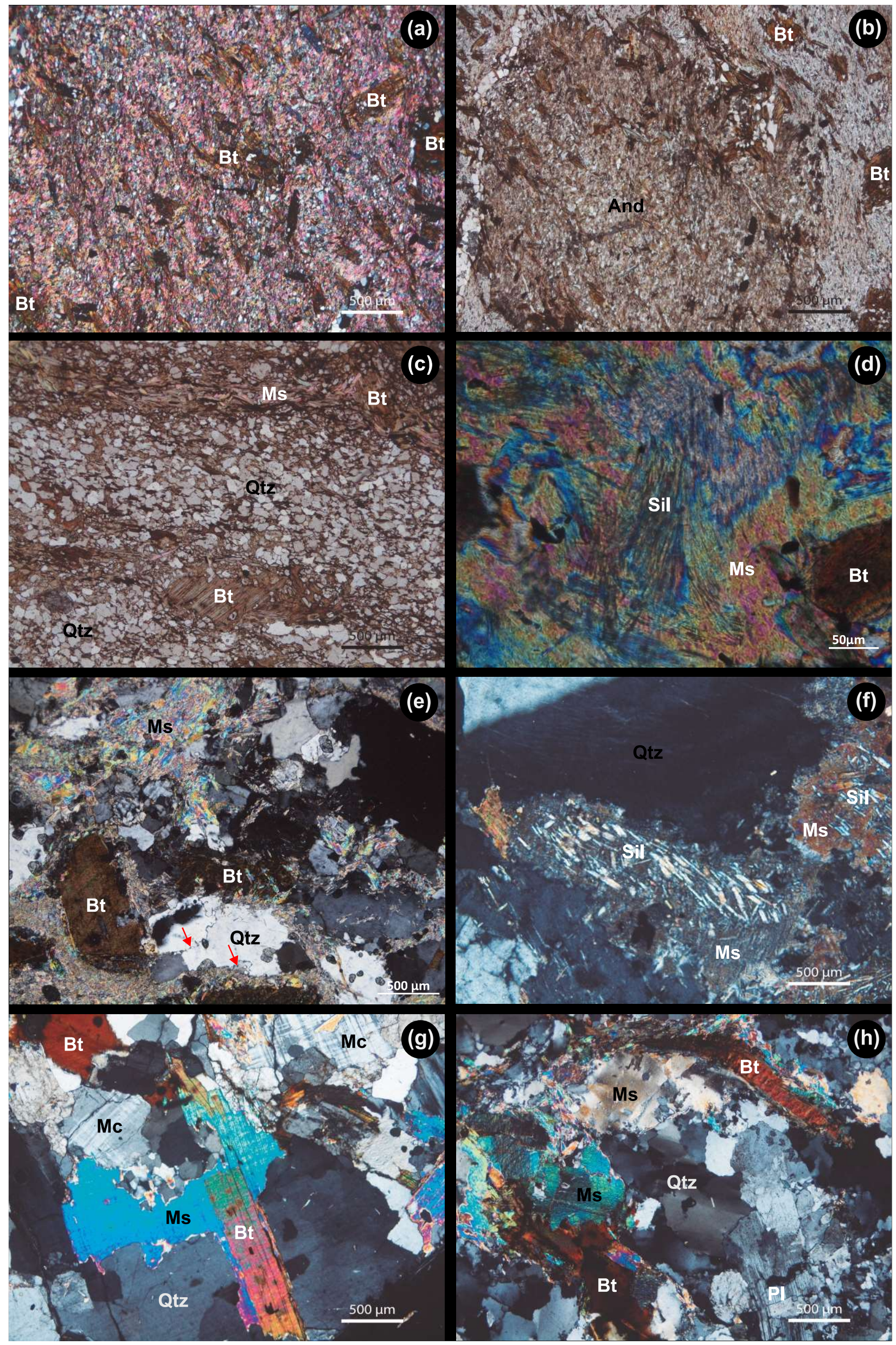

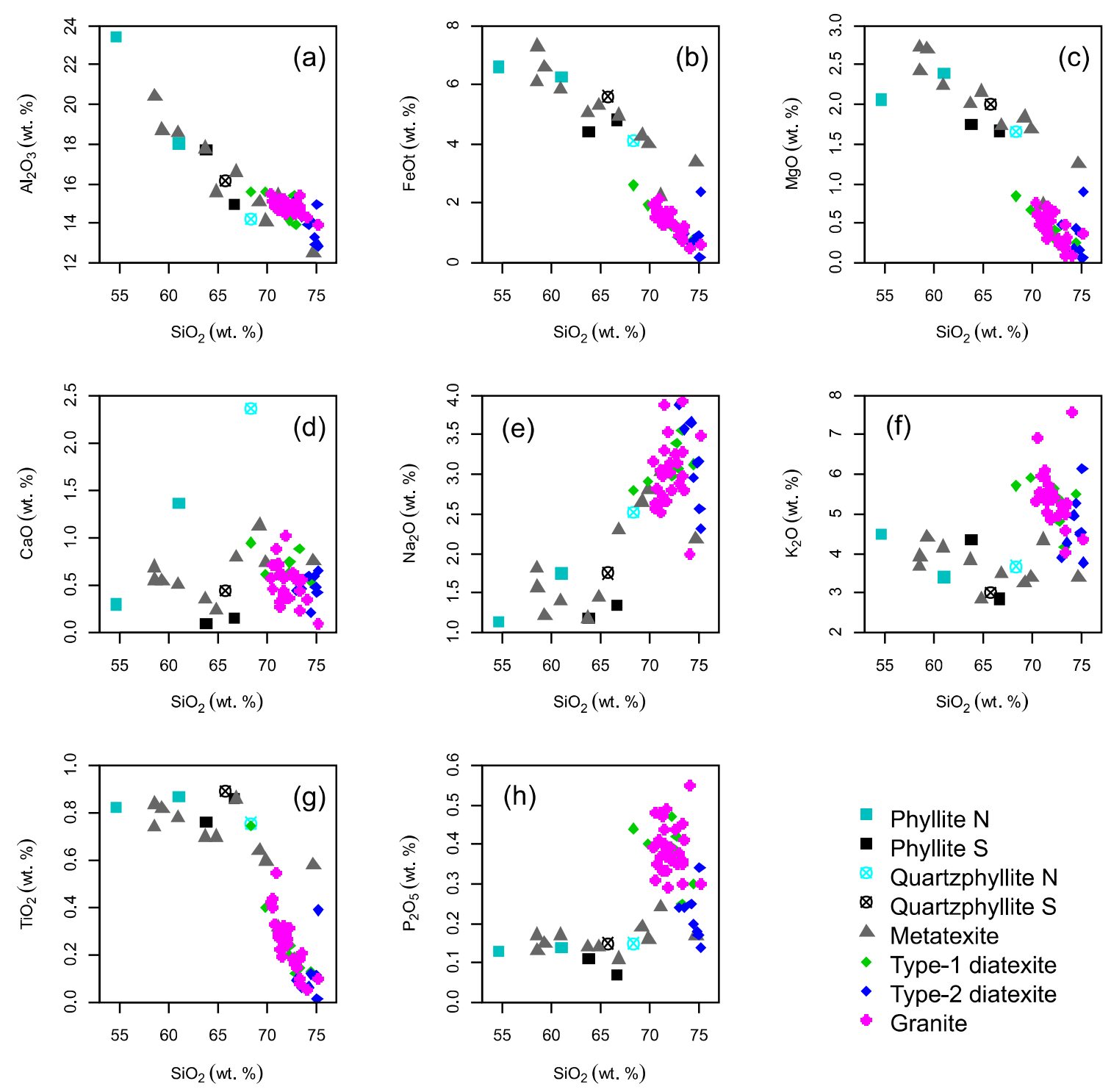

- Phyllite N

- Phyllite S

Quartzphyllite N

$\otimes$ Quartzphyllite S

- Metatexite

- Type-1 diatexite

- Type-2 diatexite

- Granite 

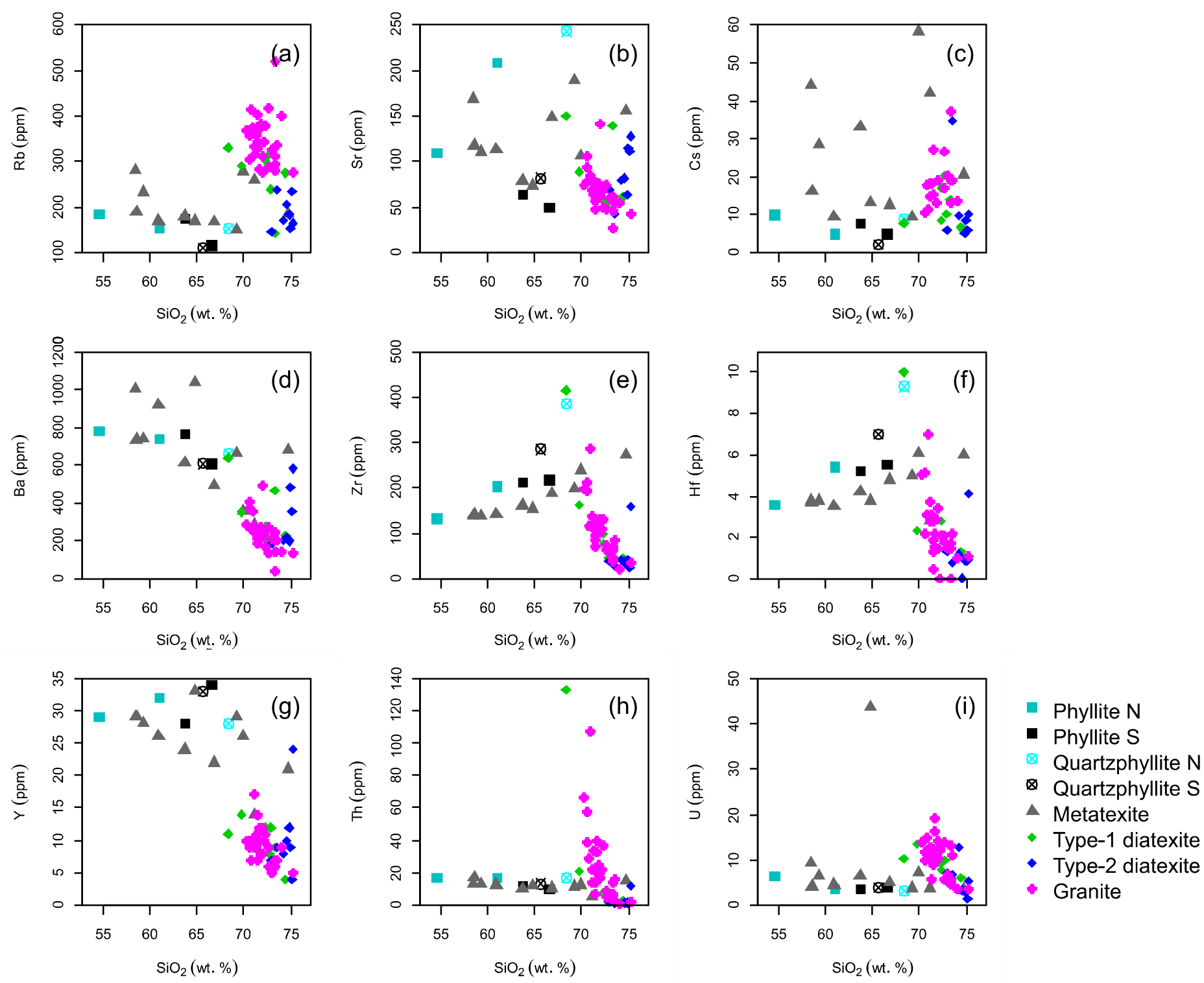


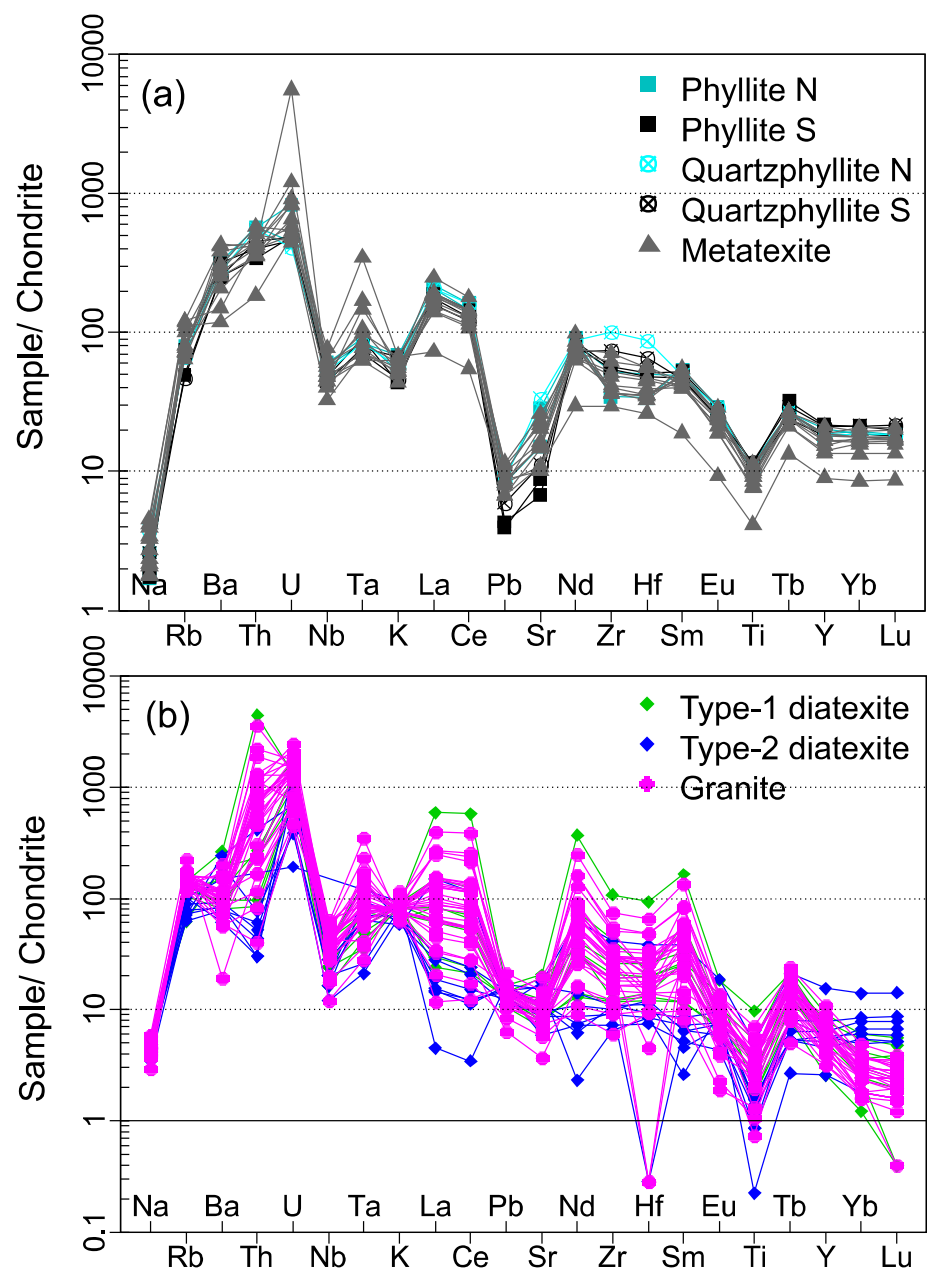



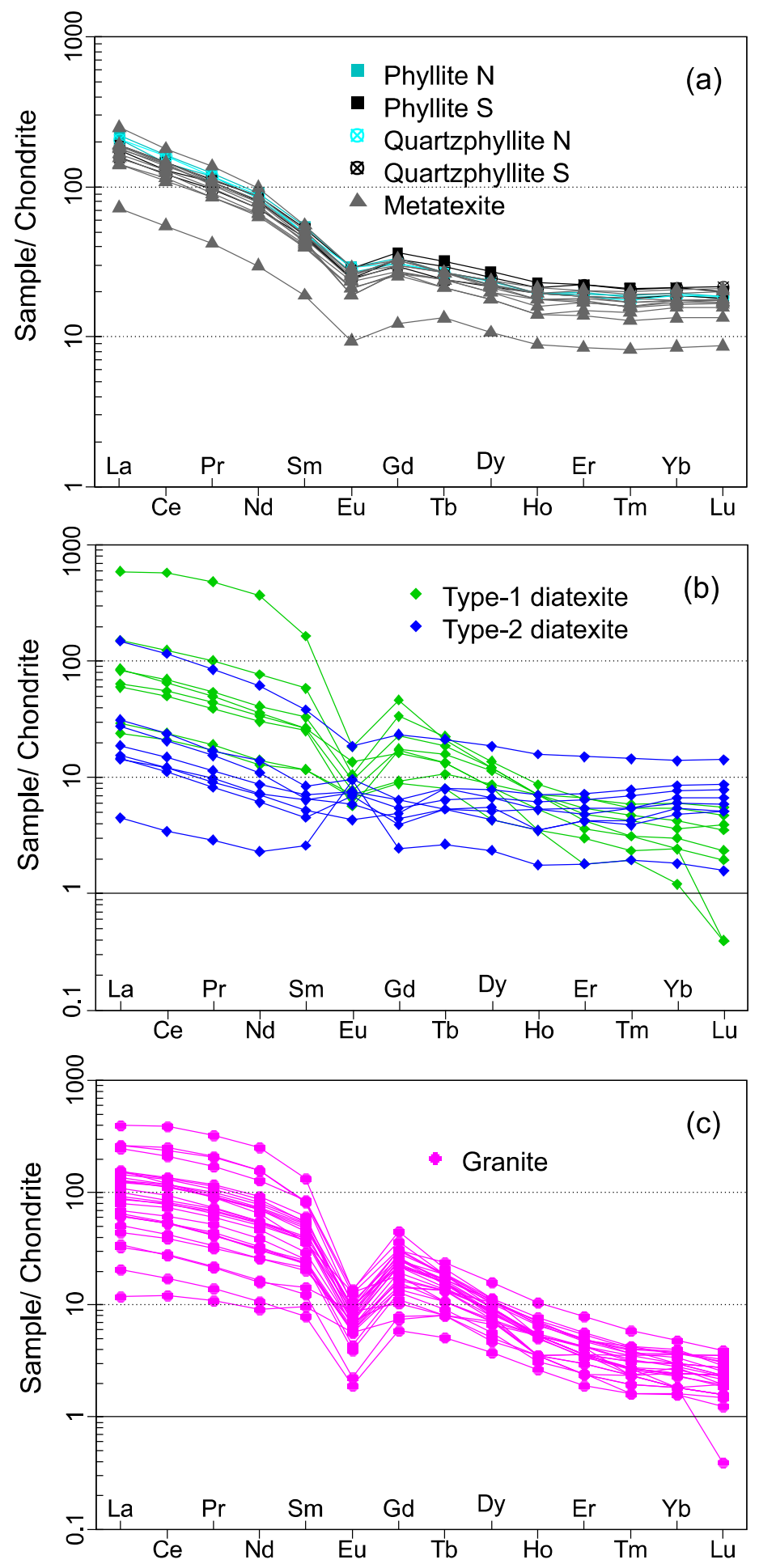
Fig.9
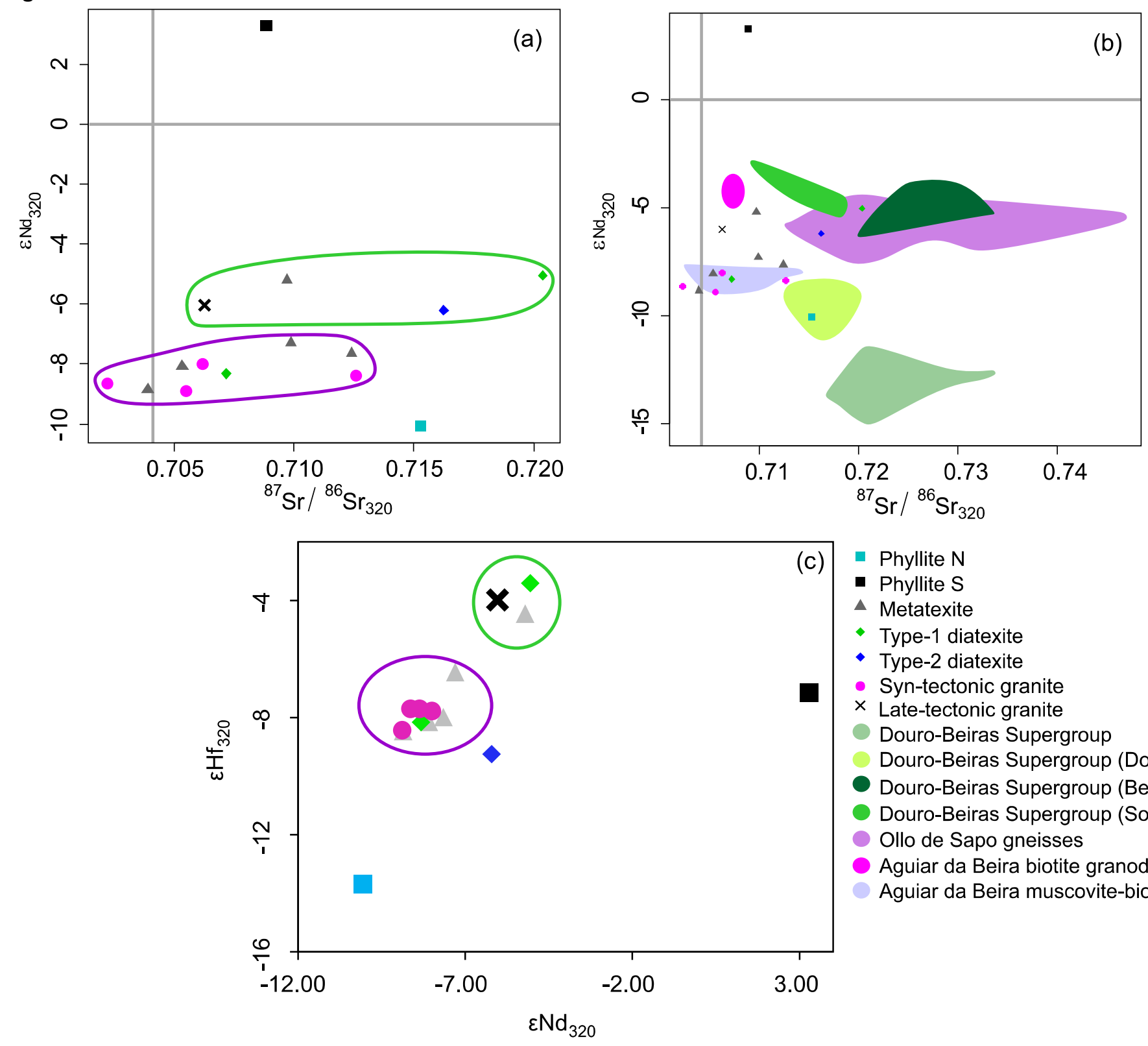

- Phyllite N

- Phyllite S

- Metatexite

- Type-1 diatexite

- Type-2 diatexite

- Syn-tectonic granite

$\times$ Late-tectonic granite

Douro-Beiras Supergroup

Douro-Beiras Supergroup (Douro group)

- Douro-Beiras Supergroup (Beiras group)

Douro-Beiras Supergroup (South $\mathrm{ClZ}$ )

Ollo de Sapo gneisses

- Aguiar da Beira biotite granodiorite-granite

Aguiar da Beira muscovite-biotite leucogranite

$\varepsilon \mathrm{Nd}_{320}$ 

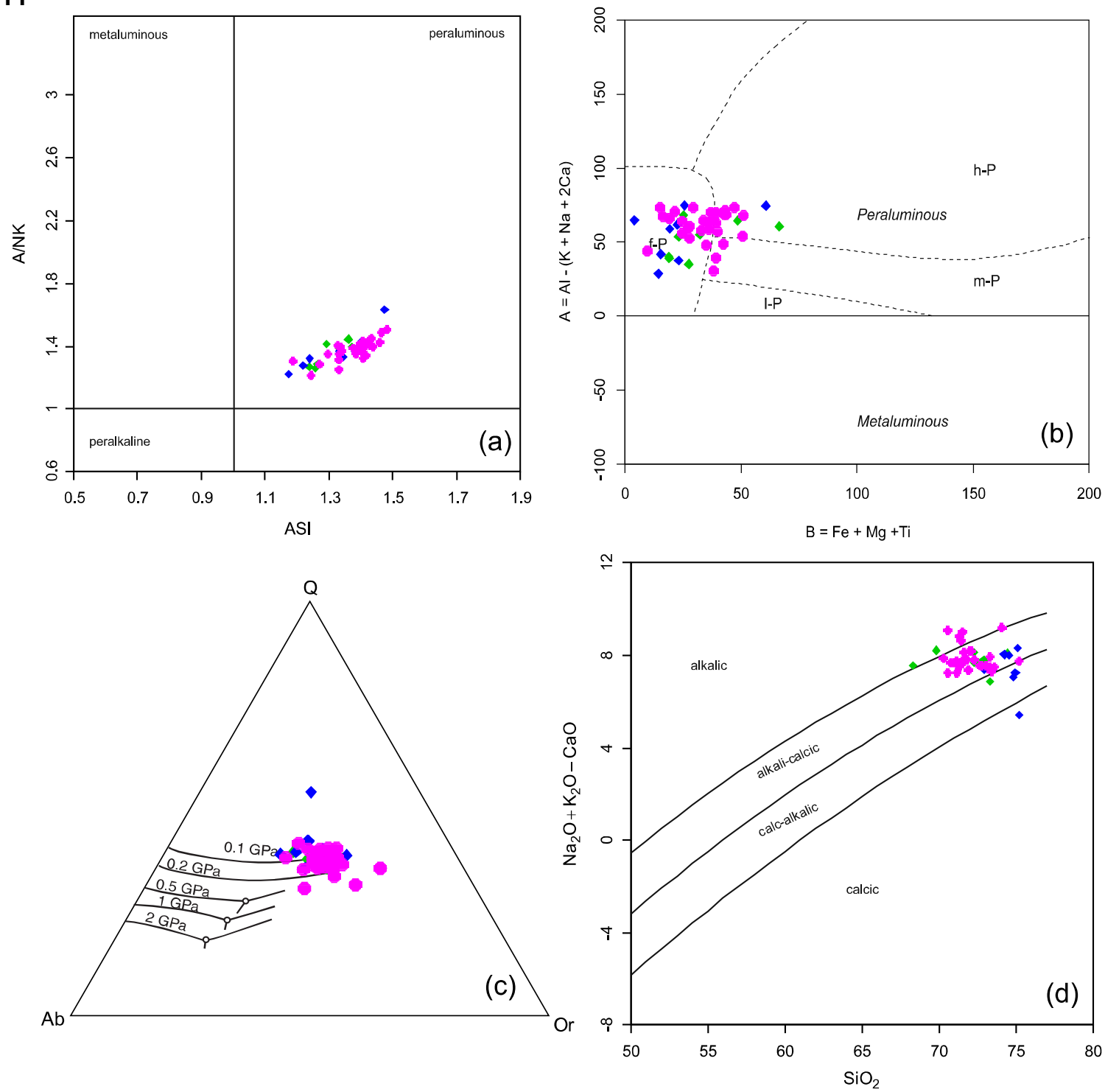

Phyllite N

- Phyllite S

Quartzphyllite N

Quartzphyllite S

- Metatexite

- Type-1 diatexite

- Type-2 diatexite

- Granite 

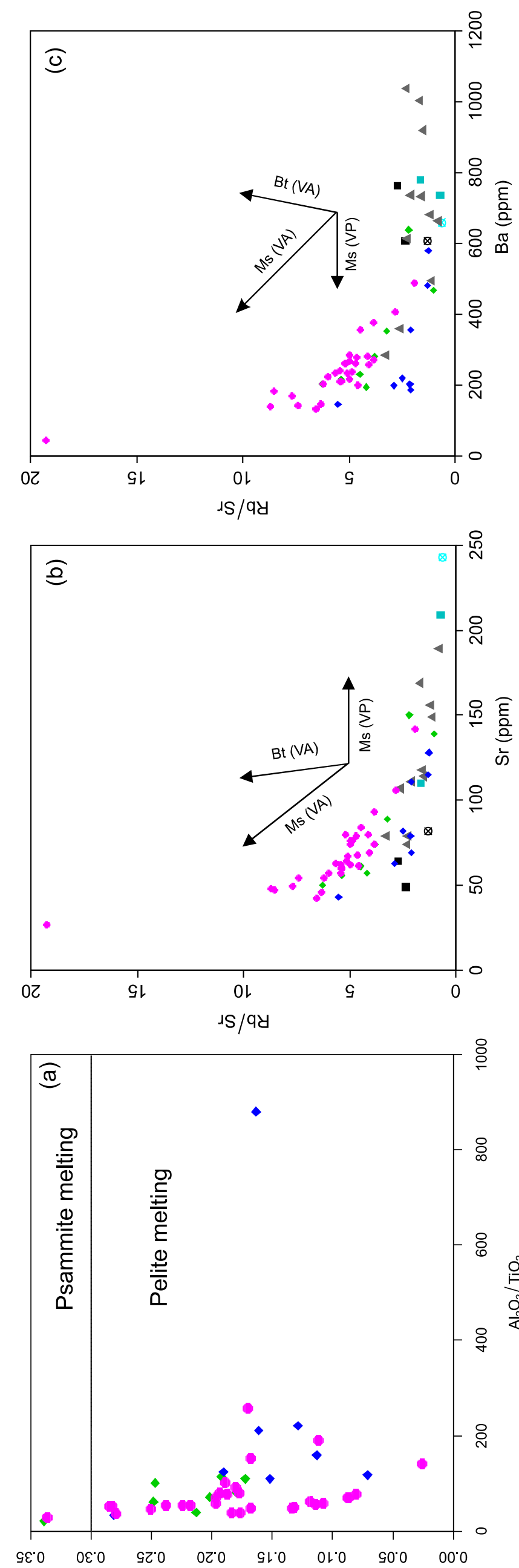

$\mathrm{o}_{\mathrm{z} \text { en/oeo }}$

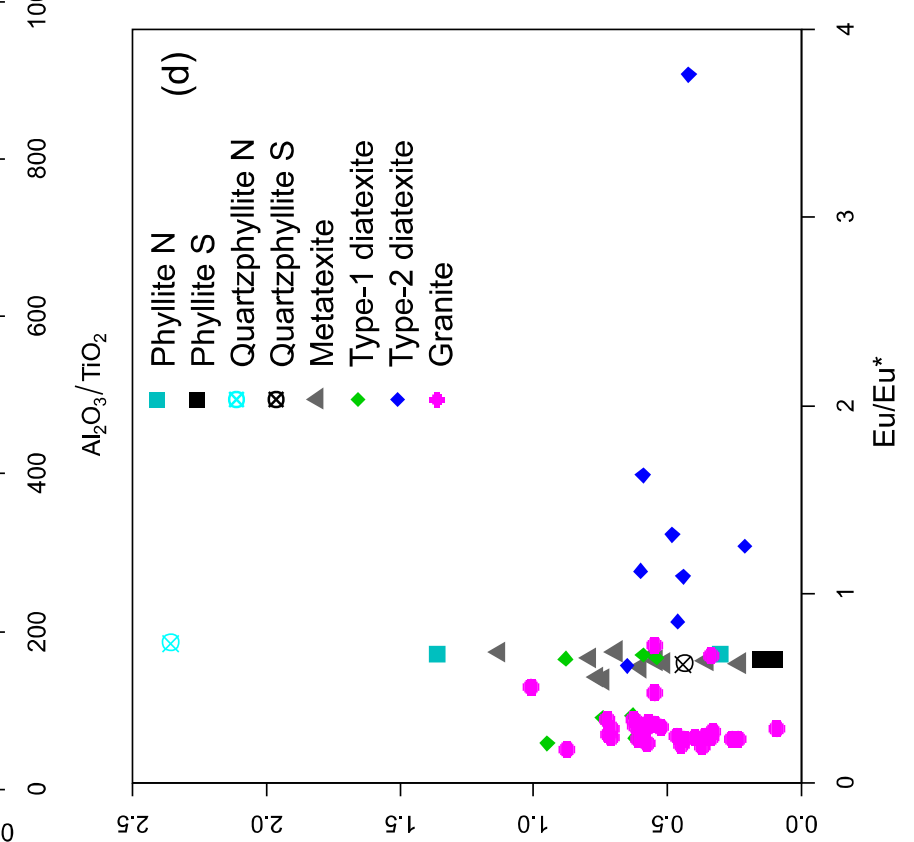

$\frac{N}{i}$

(\% ' 
Fig.13
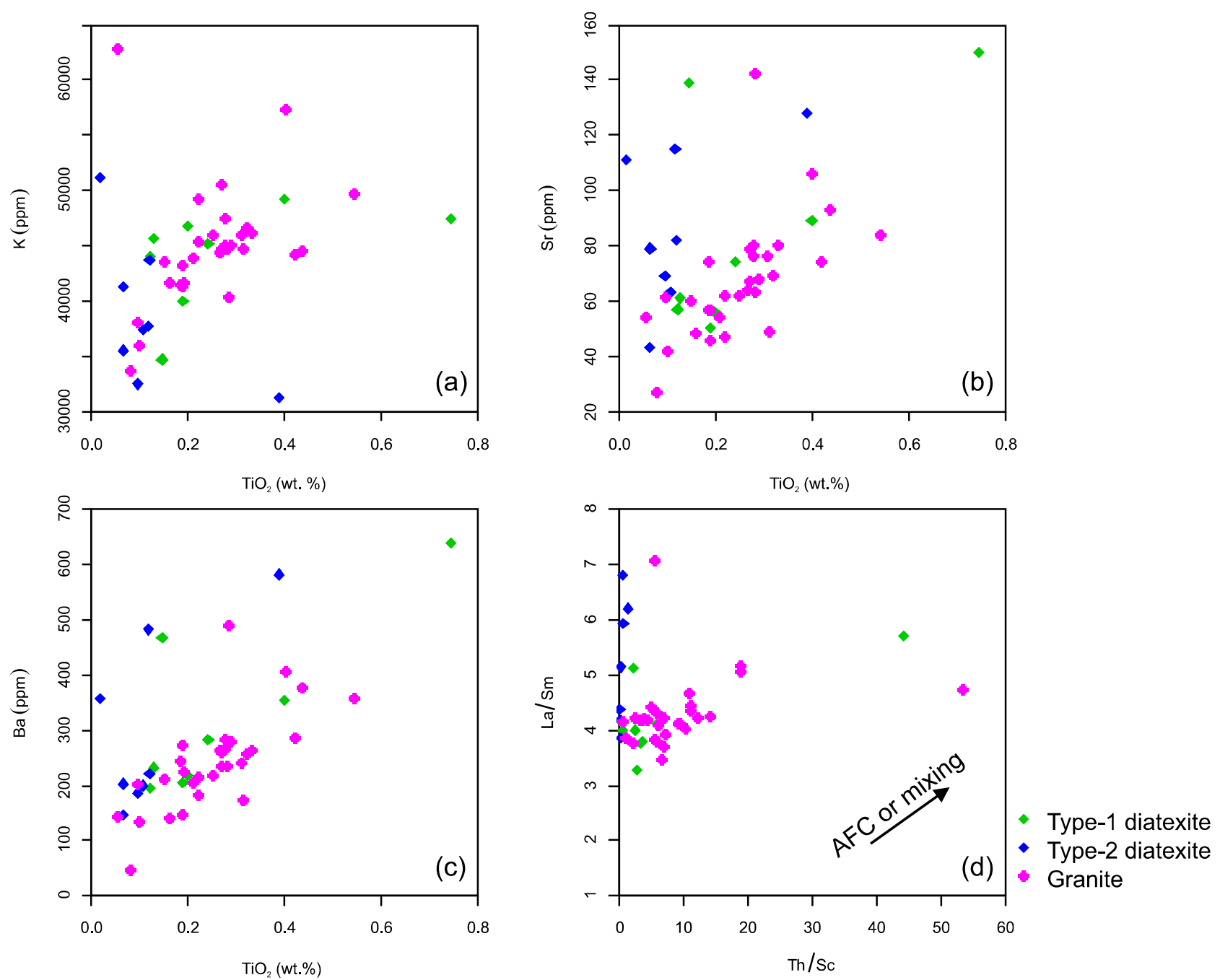


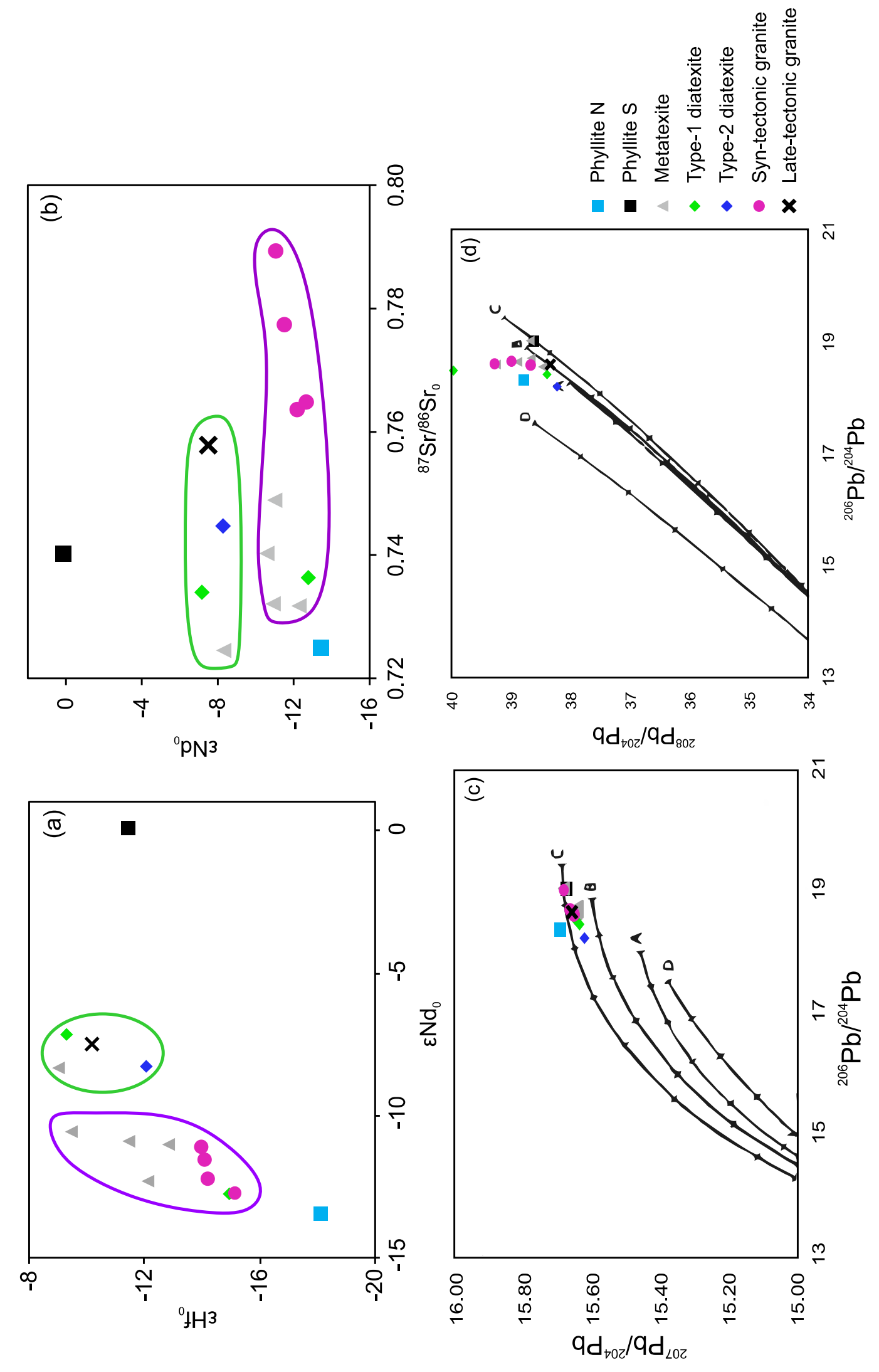

$\frac{\dot{T}}{\frac{\dot{\theta}}{i}}$ 
Fig.15
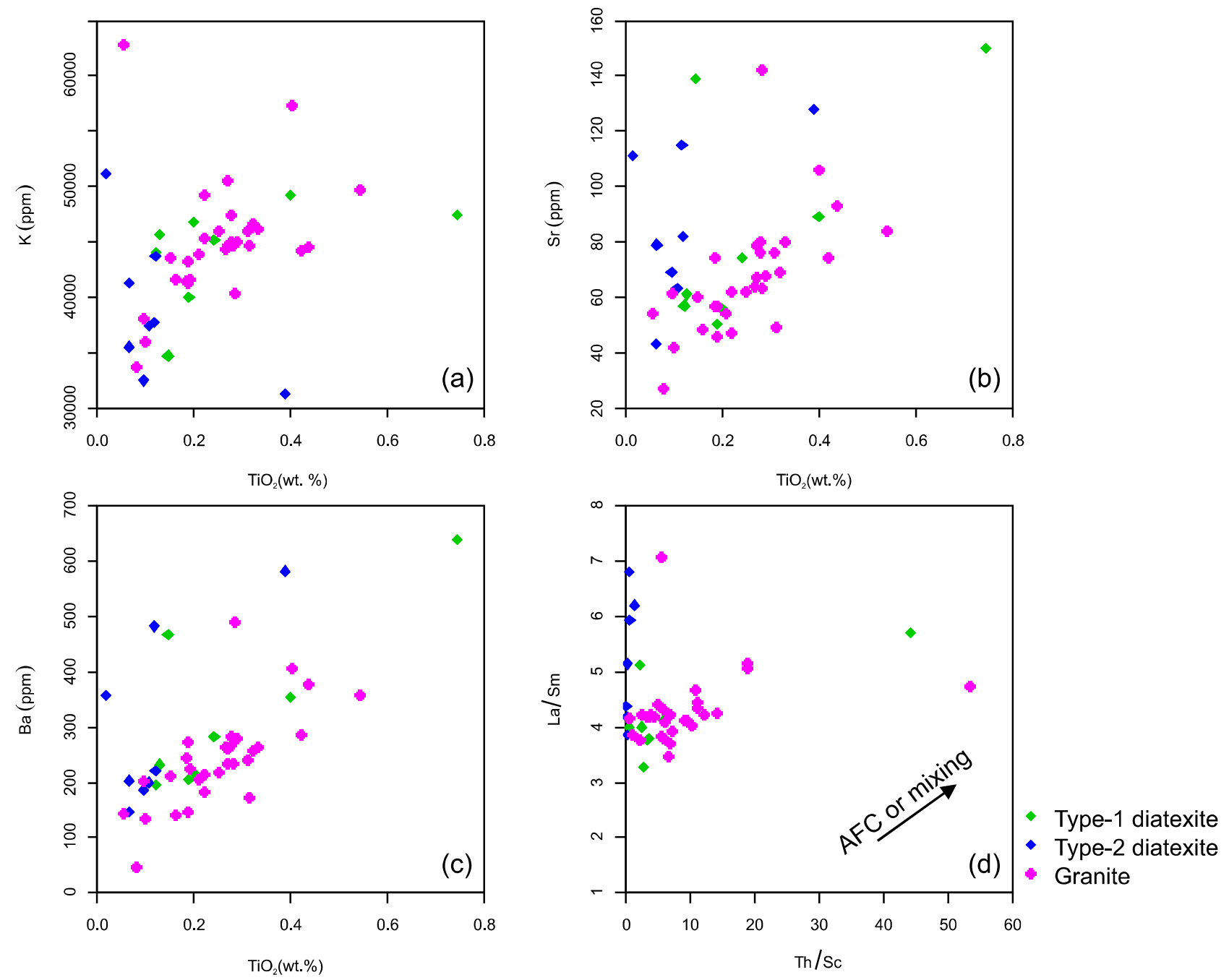